\title{
EPIDEMIOLOGY OF \\ AGE-RELATED MACULOPATHY
}


Printed by: Haveka B.V., Alblasserdam, The Netherlands.

(C) 1995 J.R. Vingerling

No part of this book may be reproduced in any form, by print, photoprint, microfilm or any other means without written permission from the author. 


\section{EPIDEMIOLOGY OF AGE-RELATED MACULOPATHY}

Epidemiologie van leeftijdgebonden maculopathie

\section{PROEFSCHRIFT}

Ter verkrijging van de graad van doctor aan de Erasmus Universiteit Rotterdam

op gezag van de Rector Magnificus

Prof. Dr, P.W.C. Akkermans M.A.

en volgens het besluit van het College voor Promoties.

De openbare verdediging zal plaatsvinden op woensdag 24 mei 1995 om 13.45 uur

door

JOHANNES RIENKO VINGERLING

geboren te Gouda 


\section{PROMOTIECOMMISSIE}

Promotores: Prof. Dr. P.T.V.M. de Jong Prof. Dr. A. Hofman

Overige leden: Prof. Dr. F.T. Bosman

Prof. Dr. S.W.J. Lamberts

Prof. Dr. D. van Norren 


\section{ACKNOWLEDGEMENTS}

The author gratefully acknowledges the collaboration in various parts of this study with the Department of Ophthalmology, University Hospital Rotterdam-Dijkzigt (Prof. Dr. P.T.V.M. de Jong); the Department of Epidemiology \& Biostatistics, Erasmus University, Rotterdam (Prof. Dr. A. Hofman, Prof. Dr. D.E. Grobbee, Prof. Dr. R. van Strik); the Department of Internal Medicine III, University Hospital Rotterdam-Dijkzigt (Prof. Dr. J.C. Birkenhäger, Dr. H.A.P. Pols); the Department of Ophthalmology, University of Wisconsin, Wisconsin, USA (Prof. Dr. R. Klein); the TNO Institute for Perception, Soesterberg (Prof. Dr. D. van Norren); the Moorfields Eye Hospital, London, England (Prof. Dr. A. Bird, Dr. R. Wormald); The University of Creteill, Paris, France (Prof. Dr. G. Coscas); the Department of Ophthalmology, John Hopkins University, Baltimore, USA (Prof. Dr. N.M. Bressler) and the general practitioners and pharmacists of Ommoord, Rotterdam.

This study is supported by grants from the NESTOR program for geriatric research (supported by the Netherlands Ministries of Health and Education); Topcon Europe BV; Haagsch Oogheelkundig Fonds; Stichting Blindenhulp; Merck, Sharp \& Dohme - Chibret Nederland; Rotterdamse Vereniging voor Blindenbelangen; Netherlands Society for the Prevention of Blindness; Stichting Bevordering Volkskracht; Stichting Fondsenwerving Volksgezondheid; Verhagen Stichting; the Netherlands Heart Foundation and the Netherlands Prevention Fund; Stichting voor Ooglijders and Stichting ROOS. 



\section{CONTENTS}

Acknowledgements

Chapter 1: Introduction 1

Chapter 2: Epidemiology of age-related maculopathy 3

Chapter 3: An international classification and grading system for age-related maculopathy and age-related macular degeneration

Chapter 4: Prevalence of age-related maculopathy in the Rotterdam Study

Chapter 5: Atherosclerosis and age-related macular degeneration

Chapter 6: Smoking and age-related macular degeneration

Chapter 7: Is age-related macular degeneration associated with early menopause?

Chapter 8: General discussion

Chapter 9: Summary

Chapter 10: Samenvatting

Nawoord

Curriculum vitae 


\section{PUBLICATIONS AND MANUSCRIPTS BASED ON STUDIES DESCRIBED IN THIS THESIS}

\section{Chapter 2.}

Vingerling JR, Klaver CCW, Hofman A, de Jong PTVM. Epidemiology of agerelated maculopathy. (submitted).

\section{Chapter 3.}

Bird AC, Bressler NM, Bressler SB, Chisholm IH, Coscas G, Davis MD, de Jong PTVM, Klaver CCW, Klein BEK, Klein R, Mitchell P, Sarks JP, Sarks SH, Soubrane G, Taylor HR, Vingerling JR. An international classification and grading system for age-related maculopathy and age-related macular degeneration. Surv Ophthalmol (in press).

\section{Chapter 4.}

Vingerling JR, Dielemans I, Hofman A, Grobbee DE, Hijmering M, Kramer CFL, de Jong PTVM. Prevalence of age-related maculopathy in the Rotterdam Study. Ophthalmology 1995;102:205-10.

Chapter 5.

Vingerling JR, Dielemans I, Bots ML, Hofman A, Grobbee DE, de Jong PTVM. Atherosclerosis is associated with age-related maculopathy. The Rotterdam Study. Am J Epidemiol (in press).

\section{Chapter 6.}

Vingerling JR, Dielemans I, Hofman A, Grobbee DE, de Jong PTVM. Smoking and macular degeneration. The Rotterdam Study. (submitted).

\section{Chapter 7.}

Vingerling JR, Dielemans I, Witteman JCM, Hofman A, Grobbee DE, de Jong PTVM. Is macular degeneration associated with early menopause? BMJ (in press). 


\section{CHAPTER 1}

\section{INTRODUCTION}

In 1875, Pagenstecher and Genth provided the first description of age-related maculopathy (ARM) (1). Nowadays, hundred and twenty years after the first description, ARM is one of the major causes of severe irreversible visual loss in the elderly in western countries. It has been estimated that there are 640000 people aged 75 years or older in the United States who have signs of the endstage of this disease (2). Still, our knowledge about the etiology of ARM is very limited and treatment is only possible in a minority of patients.

The Framingham Eye Study (3) was the first population-based study that provided information about prevalence and risk factors for ARM. Since then, several epidemiologic studies on the disease have been performed, most of them in the USA. A review of the epidemiological knowledge obtained in these studies is given in chapter 2 of this thesis. Since until recently a uniform classification of ARM has not been available, comparison of the results of different studies has for years been a problem. Chapter 3 presents the results of several international meetings of six research groups with the aim to develop a uniform classification system for ARM.

Little information was available on the prevalence of ARM in the Netherlands. The Rotterdam Study (4), however, provided an excellent opportunity to answer several research questions into the epidemiology of the disease. The results of the prevalence study are presented in chapter 4 . The remainder of this thesis focuses on risk factors of the late stages of the disease, atrophic and neovascular agerelated macular degeneration (AMD). In chapter 5, the associations of various indicators of atherosclerosis and the late stages of the disease are described. Chapter 6 presents the association between smoking and AMD and in chapter 7 the relation with age of menopause and is described. Methodological issues related to the presented studies are discussed in chapter 8, together with a review of the results of these studies and suggestions for future research. 


\section{Introduction}

\section{REFERENCES}

1. Pagenstecher, Genth. Atlas der Pathologische Anatomie des Augenapfels. CW Kriedel. 1875 Wiesbaden.

2. Klein R, Klein BEK, Linton KLP. Prevalence of age-related maculopathy. The Beaver Dam Eye Study. Ophthalmol 1992;99:933-43.

3. Leibowitz H, Krueger DE, Maunder LR et al. The Framingham Eye Study Monograph; an ophthalmological and epidemiological study of cataract, glaucoma, diabetic retinopathy, macular degeneration, and visual acuity in a general population of 2631 adults, 1973-1977. Surv Ophthalmol. $1980 ; 24: 335 \cdot 610$.

4. Hofman A, Grobbee DE, Jong PTVM de, Ouweland FA van den, Determinants of disease and disability in the elderly: the Rotterdam Elderly Study. Eur J Epidemiol. 1991;7:403-22. 


\section{EPIDEMIOLOGY OF AGE-RELATED MACULOPATHY}

Age-related maculopathy (ARM), formerly referred to as senile macular degeneration, is the leading cause of permanent visual impairment among the elderly in western countries (1-4). The loss of vision is a result of degeneration of the photoreceptors in the centre of posterior pole of the eye, the macular area, and occurs when the retinal pigment epithelium cells with which they are associated deteriorate and die. Because useful intervention is limited to only a minority of patients $(5,6)$, various epidemiological studies have focused on this disease in an attempt to find etiological clues. In this article we will review the current epidemiological knowledge concerning ARM and discuss diagnosis, frequency, risk factors and prognosis.

\section{DIAGNOSIS}

\section{Diagnostic criteria}

ARM affects the centre of the retina and choroid in the macula lutea of the eye. Generally, it is considered to be present when one or more of the following changes are visible in the macular area:

- drusen: yellow deposits below the retinal pigment epithelial cells;

- hyper- and hypopigmentary changes of the retinal pigment epithelium;

- atrophic age-related macular degeneration (atrophic AMD): well defined areas of atrophy of the retinal pigment epithelium and choriocapillaris;

- neovascular age-related macular degeneration (neovascular AMD): serous or haemorrhagic detachment of the pigment epithelium, choroidal neovascularization and subsequent scarring of the macular area.

Although these changes are all manifestations of the disease and associated with increasing age, they show a large range of variety, and for years this has been an obstacle for a uniform definition and classification system. Early epidemiological studies have included decreased central visual acuity as one of the diagnostic criteria. Recently, however, three grading systems have been developed to classify ARM on colour photographs of the macula lutea without implication of visual acuity (7-9). The definitions of these grading systems are summarized in Table 1. In brief, the system of Bressler et al. consists of four categories, and at each step from category one to four, the system leaves out less severe abnormalities. The Wisconsin Age-Related Maculopathy Grading System provides a detailed grading of each abnormality with respect to its size, area and location. It defines early and late stages of ARM (10).

Presently, an international study group has developed a classification system 


\section{Epidemiology of age-related maculopathy}

Table 1. Classification of ARM.

\begin{tabular}{|c|c|c|}
\hline Bressler et al. (7) & $\begin{array}{l}\text { Wisconsin Age-related } \\
\text { Maculopathy Grading } \\
\text { System. (8) }\end{array}$ & $\begin{array}{l}\text { The International Age- } \\
\text { Related Maculopathy } \\
\text { Study Group (9) }\end{array}$ \\
\hline $\begin{array}{l}\text { Grade } 1: \text { Presence of } \\
\text { grade } 4,3 \text { or } 2 \text {, or eyes } \\
\text { with at least five small } \\
\text { drusenwithin } 1,500 \mu \mathrm{m} \text { of } \\
\text { the foveal center or at } \\
\text { least ten small drusen } \\
\text { between } 1,500 \text { and } 3,000 \\
\mu \mathrm{m} \text { from the foveal } \\
\text { center. }\end{array}$ & \multirow[t]{3}{*}{$\begin{array}{l}\text { Early age-related } \\
\text { maculopathy: Soft } \\
\text { indistinct or reticular } \\
\text { drusen or any drusen } \\
\text { type except hard } \\
\text { indistict, with retinal } \\
\text { pigment epithelium } \\
\text { degeneration or } \\
\text { increased retinal pigment } \\
\text { in the macular area and } \\
\text { the absence of late age- } \\
\text { related maculopathy. }\end{array}$} & \multirow[t]{3}{*}{$\begin{array}{l}\text { Age-related maculopathy: } \\
\text { All stages of the disease: } \\
\text { Within this definition } \\
\text { drusen and pigmentary } \\
\text { changes are subdivided by } \\
\text { aspect, number and size. }\end{array}$} \\
\hline $\begin{array}{l}\text { Grade } 2: \text { Presence of } \\
\text { grade } 4 \text { or } 3 \text {, or eyes with } \\
\geq \text { twenty small drusen } \\
\text { within } 1,500 \mu \mathrm{m} \text { of the } \\
\text { foveal center. }\end{array}$ & & \\
\hline $\begin{array}{l}\text { Grade 3: Presence of } \\
\text { grade 4, or eyes with } \\
\text { large or confluent drusen, } \\
\text { or eyes with focal } \\
\text { hyperpigmentation of the } \\
\text { retinal pigment } \\
\text { epithelium. }\end{array}$ & & \\
\hline $\begin{array}{l}\text { Grade 4: Geographic } \\
\text { atrophy of the retinal } \\
\text { pigment epithelium or } \\
\text { exudative changes (eg. } \\
\text { choroidal } \\
\text { neovascularization, } \\
\text { detachment of the retinal } \\
\text { pigment epithelium, and } \\
\text { disciform scarring). }\end{array}$ & $\begin{array}{l}\text { Late age-related } \\
\text { maculopathy: } \\
\text { Signs of exudative age- } \\
\text { related maculopathy or } \\
\text { geographic atrophy. }\end{array}$ & $\begin{array}{l}\text { Age-related macular } \\
\text { degeneration: the end } \\
\text { stages of age-related } \\
\text { maculopathy subdivided in } \\
\text { dry or geographic and wet } \\
\text { or neovascular age-related } \\
\text { macular degeneration }\end{array}$ \\
\hline
\end{tabular}




\section{Chapter 2}

to facilitate comparison of data between the various epidemiological studies (9). This system defines age-related maculopathy as all manifestations of this disorder; the late stages of ARM are called age-related macular degeneration (AMD) subdivided in atrophic and wet or neovascular AMD. For the purpose of this review, we will describe the separate features of ARM.

\section{Differential diagnosis}

Drusen must be differentiated from other conditions with white spots in the macula like hard exudates, cotton wool spots and retinal pigment epithelium hypopigmentations such as in fundus flavimaculatus and fundus albipunctatus. Pigmentary changes can also be seen in combination with other abnormal processes in the macular area which are not directly related to ARM, like those accompanying chorioretinal scars due to chorioretinitis, trauma or laser photocoagulation.

Any chorioretinal inflammation or scar may result in the growth of a subretinal neovascular membrane. Therefore, neovascular AMD sometimes resembles similar conditions in myopic macular degeneration, pseudoxanthoma elasticum, Paget disease, presumed ocular histoplasmosis syndrome, toxoplasmosis, central areolar choroidal sclerosis $(11,12)$. laser photocoagulation scars and traumatic, inflammatory, toxic, and congenital processes (8). In general, these disorders have to be excluded by fundoscopic assessment, before a diagnosis of ARM can be made.

\section{FREQUENCY}

\section{Prevalence}

Estimation of the prevalence of ARM is not only necessary for assessing the need for ophthalmological care, but comparison of prevalence figures from different populations may also suggest etiological clues to the disease. Population-based studies of ARM were conducted in the United States, Europe and New Zealand (Table 2). Studies from Framingham (2), Gisborne (13), Melton Mowbray (13a), Copenhagen (14) and the National Health and Nutrition Examination Survey (NHANES) (15) estimated the prevalence of any type of ARM based on ophthalmoscopical assessment of macular changes in combination with loss of central visual acuity. As is shown in Figure 1, the prevalence estimates in these studies vary considerably. The studies from Chesapeake Bay (7) and Beaver Dam (10) based their data on photographic grading of macular changes and did not require visual loss for the diagnosis ARM, which may explain why their prevalence estimates for any type of ARM are higher (Figure 1). Whatever definition or method of diagnosis, all estimates show a strong rise with age, and a reasonable overall prevalence for any type of ARM in the age-groups 65-74 years and 75-84 years is 20 and 35 percent, respectively. 
Epidemiology of age-related maculopathy

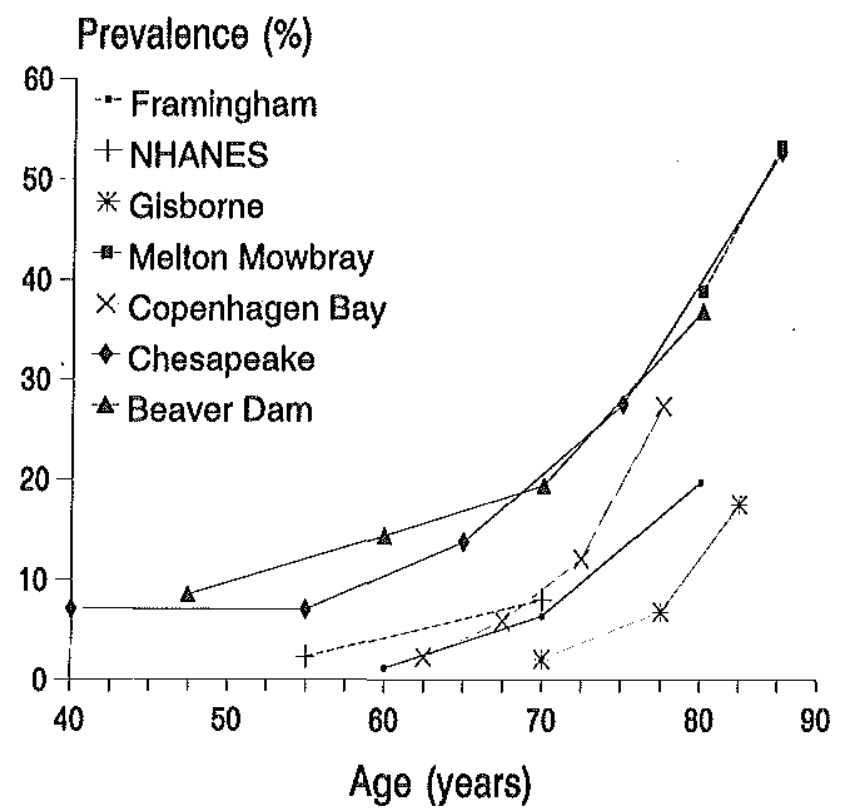

Figure 1. Age-specific prevalence of ARM (all types). 


\begin{tabular}{|c|c|c|c|c|c|c|c|}
\hline \multirow[b]{2}{*}{ Site (reference no.) } & \multicolumn{3}{|l|}{ Criteria for diagnosis } & \multirow{2}{*}{ Grading method } & \multirow{2}{*}{$\begin{array}{l}\text { Age range } \\
(\mathrm{yr})\end{array}$} & \multirow{2}{*}{$\begin{array}{l}\text { Sample } \\
\text { size }\end{array}$} & \multirow{2}{*}{$\begin{array}{l}\text { Response } \\
\text { rate }\end{array}$} \\
\hline & Fundus abnormalities & Grading area" & $\begin{array}{l}\text { Visual } \\
\text { acuity }\end{array}$ & & & & \\
\hline Framingham (2) & $\begin{array}{l}\text { Drusen; pigment disturbances; geographic } \\
\text { atrophy; exudative macular degeneration. }\end{array}$ & Posterior pole & $<20 / 30$ & Ophthalmoscopy & $52-84$ & 2675 & 67 \\
\hline NHANES (15) & $\begin{array}{l}\text { Drusen; pigment disturbances; loss of } \\
\text { macular reflex; geographic atrophy; } \\
\text { exudative macular degeneration. }\end{array}$ & Posterior pole & $<20 / 25$ & Ophthalmoscopy & $45-74$ & 1413 & 72 \\
\hline Gisborn (13) & $\begin{array}{l}\text { Drusen; pigment disturbances; geographic } \\
\text { atrophy; exudative macular degeneration. }\end{array}$ & Posterior pole & $<20 / 30$ & Ophthalmoscopy & $65+$ & 481 & 82 \\
\hline Melton Mowbray (13a) & $\begin{array}{l}\text { Drusen; pigment disturbances; geographic } \\
\text { atrophy; exudative macular degeneration. }\end{array}$ & Posterior pole & $<20 / 30$ & Ophthalmoscopy & $75+$ & 484 & 72 \\
\hline Iceland (113) & $\begin{array}{l}\text { Drusen; pigment disturbances; geographic } \\
\text { atrophy; exudative macular degeneration. }\end{array}$ & Posterior pole & $<20 / 30$ & Ophthalmoscopy & $43+$ & 751 & 81 \\
\hline Copenhagen (14) & $\begin{array}{l}\text { Drusen; pigment disturbances; geographic } \\
\text { atrophy; exudative macular degeneration. }\end{array}$ & Posterior pole & $<20 / 30$ & Ophthalmoscopy & $60-79$ & 1000 & 71 \\
\hline Chesapeake Bay (7) & $\begin{array}{l}\text { Drusen, number, size and distinction of } \\
\text { borders; focal hyperpigmentations; non- } \\
\text { geographic atrophy; geographic atrophy and } \\
\text { exudative macular degeneration. }\end{array}$ & $\begin{array}{l}1500 \mu \mathrm{mon} \\
3000 \mu \mathrm{ma}\end{array}$ & - & Photography & $30-95$ & 777 & 70 \\
\hline Beaver Dama (10) & $\begin{array}{l}\text { Drusen area, number, size and distinction } \\
\text { of borders; increased or decreased retinal } \\
\text { pigment; geographic atrophy; exudative } \\
\text { macular degeneration. }\end{array}$ & $3000 \mu \mathrm{m}$ & - & Photography & $43-84$ & 4926 & 83 \\
\hline Rotterdam (114) & $\begin{array}{l}\text { Drusen, nuraber and size; increased or } \\
\text { decreased retinal pigment; geographic } \\
\text { atrophy; exudative macular degeneration }\end{array}$ & $3000 \mu \mathrm{m}$ & - & Photography & $55+$ & 7599 & 78 \\
\hline
\end{tabular}

$\checkmark *$ radius of grading area centered on the fovea. 


\section{Epidemiology of age-related maculopathy}

Separate prevalence estimates of atrophic or neovascular AMD are available from studies in Framingham, Iceland, Chesapeake Bay, Beaver Dam and Rotterdam (Figure 2). The first two studies based their estimates only on neovascular AMD, while the latter three also included atrophic AMD. These prevalence estimates of ARM show less variation than with inclusion of drusen and pigmentary changes, and the estimates show an almost exponential increase after the age of 70 years. A reasonable overall prevalence of neovascular and/or atrophic AMD in the age-groups 65-74 years and 75-84 years is 1 and 5 percent, respectively. Although none of the other studies showed any prevalence difference in gender, the Beaver Dam study noted that women had a 2.5 times higher prevalence for neovascular AMD than men (10).

\section{Incidence}

No data based on incidence studies of ARM are available. If the prevalence is low, an estimated incidence rate can be obtained indirectly using prevalence and expected duration of the disease (16). With this method, the incidence rate of atrophic or neovascular AMD in the age group of 75-84 years is approached by the prevalence ( 7.1 per 100) divided by the estimated mean duration of 5 years, which results in an incidence rate (density) of 1.4 per 100 person-years.

\section{Methodological considerations}

The difference in definitions and methodology between studies hampers the comparison of prevalence data (Table 2). In the studies from Framingham, NHANES, Gisborne, Iceland and Copenhagen, the diagnosis of ARM was only made in patients with central visual loss. This led to lower prevalence rates than the estimates from Chesapeake Bay and Beaver Dam, which did not use this criterium. In addition, the former studies based the diagnosis on ophthalmoscopy, whereas the latter based their grading on fundus photographs. It is known that with ophthalmoscopy an underestimation of the frequency of drusen can occur (2) which may be an extra reason for the higher prevalence of ARM in these studies. The Chesapeake Bay study was designed to study the relation between sunlight exposure and ARM. The study population consisted of a selected group of fishermen and this may have influenced the prevalence rate. Despite these differences, however, there is a similarity in trends: all studies show an acceleration of prevalence with increasing age (Figure 1).

The comparison of the prevalence of endstages of ARM is also troubled by differences. In the studies from Framingham and Iceland, only the prevalence of neovascular AMD was reported. Atrophic AMD was pooled with drusen and pigmentary changes in these studies. In Chesapeake Bay, Beaver Dam and Rotterdam, atrophic and neovascular AMD were pooled resulting in a higher estimate of prevalence. The differences between prevalences in these studies are therefore likely to be the result of differences in methodology and definition. 
Chapter 2

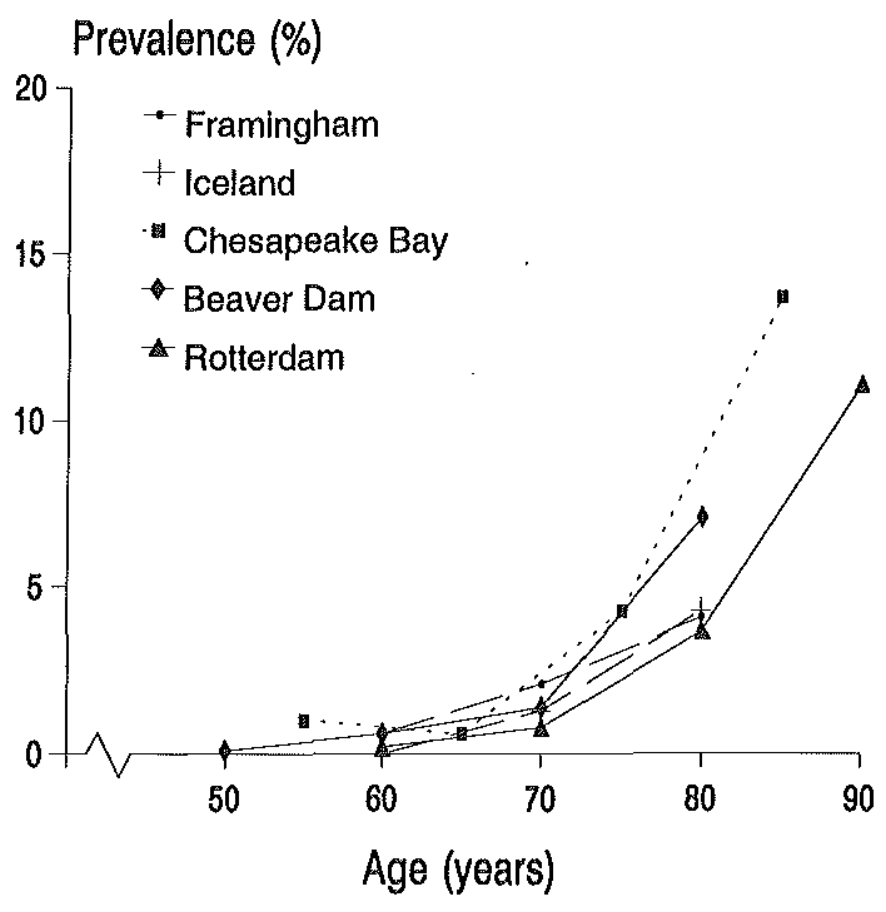

Figure 2. Age-specific prevalence of AMD (atrophic or neovascular). 


\section{Epidemiology of age-related maculopathy}

\section{RISK FACTORS}

\section{Methodological issues}

A number of case-control and cross-sectional studies has focused on the etiology of ARM. The main studies and findings are summarized in Tables 2,3 and 4. All studies were based on prevalent cases. The validity of the results is limited since selection bias may result from mortality and migration related to the disease. In general, recall bias occurs when cases recall exposures more frequently and thoroughly than controls, and this tends to happen when they already are wellknown risk factors. When a diagnosis is based on history data, misclassification may occur. This type of bias is likely to occur in a study of ARM, since patients often cannot differentiate this from other ocular pathology. Another point of consideration is the variation in inclusion criteria in studies. The results of these studies remain, therefore, to be confirmed in follow-up studies based on well defined incident cases in which the exposure status is measured before onset of disease.

The putative risk factors that will be discussed are the family history of ARM, ophthalmological characteristics, cardiovascular disease, hyperglycaemia, diabetes, smoking, sunlight exposure and antioxidant status.

\section{Genetic factors}

While Hutchinson and Tay have observed familial occurrence of ARM as early as 1875 (17), the disease has not been the subject of extensive genetic investigations. Familial aggregation of drusen has been reported by several studies. Early pedigree reports $(11,18-20)$ have used different terms to describe the familial drusen such as Doyne's honeycomb choroiditis, Tay's central guttate choroiditis, Holthouse-Batten's superficial choroiditis and Mallatia Levantinese. An autosomal dominant trait was suggested for these familial drusen, and they were considered to be different from drusen occurring as a consequence of age (21). However, Gass postulated in 1973 (11) that there was only one entity of drusen, all being manifestations of a heredodegenerative disorder. A recent study (22) compared 53 sibling-pairs and 50 spouse-pairs for concordance of drusen and found a significantly higher correlation of number and density of drusen between siblings than between spouses.

Family studies incorporating atrophic and/or neovascular AMD have received comparatively less attention. Two studies $(22,23)$ found a positive family history of macular disease in patients with drusen or pigmentary changes and/or atrophic and neovascular AMD. Because the majority of these family data was ascertained by interview alone, they should be interpreted with caution, since anamnestic history of an eye disease is rather unreliable (24). Recent twin research led to three case-reports (25-27) of identical twins having atrophic and/or neovascular AMD and one study of nine monozygotic twin pairs (28) having either extensive drusen or atrophic and/or neovascular AMD. Although selection bias or 
Table 3. Case-control studies of ARM.

\begin{tabular}{|c|c|c|c|c|c|}
\hline \multirow[b]{2}{*}{ Site (reference no.) } & \multicolumn{2}{|c|}{ Criteria for diagnosis } & \multirow{2}{*}{ Grading method } & \multirow{2}{*}{$\begin{array}{l}\text { Age } \\
\text { range } \\
\text { (yr) }\end{array}$} & \multirow{2}{*}{$\begin{array}{l}\text { Sample size } \\
\text { (case/control) }\end{array}$} \\
\hline & Cases & Controls & & & \\
\hline Malzman (115) & $\begin{array}{l}\text { Macular degeneration, } \\
\text { not further specified, } \\
\text { visual acuity }<20 / 30 \text {. }\end{array}$ & $\begin{array}{l}\text { Age and sex matched } \\
\text { ophthalmological patients } \\
\text { without macular degenation }\end{array}$ & Ophthalmoscopy & $52-88$ & $30 / 30$ \\
\hline Delaney (47) & $\begin{array}{l}\text { Drusen, pigment } \\
\text { clumping, neovascular } \\
\text { macular degeneration, } \\
\text { visual acuity }<20 / 30 \text {. }\end{array}$ & $\begin{array}{l}\text { Age and sex matched } \\
\text { ophthalmological patients } \\
\text { without macular degeneration }\end{array}$ & Ophthalmoscopy & $50+$ & $50 / 50$ \\
\hline Hyman (23) & $\begin{array}{l}\text { Drusen and/or more } \\
\text { severe macular } \\
\text { degeneration with some } \\
\text { visual loss. }\end{array}$ & $\begin{array}{l}\text { Age and sex matched } \\
\text { ophthalmological patients } \\
\text { without macular degeneration or } \\
\text { other exudative retinal diseases }\end{array}$ & $\begin{array}{l}\text { Fundus } \\
\text { photography }\end{array}$ & $<85$ & $228 / 237$ \\
\hline Blumenkranz (53) & $\begin{array}{l}\text { Neovascular macular } \\
\text { degeneration }\end{array}$ & $\begin{array}{l}15 \text { partners and } 8 \text { age and sex } \\
\text { matched others without } \\
\text { neovascular macular } \\
\text { degeneration or more than } 10 \\
\text { macular drusen }\end{array}$ & Not specified & $?$ & $26 / 23$ \\
\hline EDCCSG (41) & $\begin{array}{l}\text { Neovascular macular } \\
\text { degeneration }\end{array}$ & $\begin{array}{l}\text { Residents of clinic area without } \\
\text { neovascular macular } \\
\text { degeneration or drusen and } 6 / 6 \\
\text { visual acuity }\end{array}$ & $\begin{array}{l}\text { Fundus } \\
\text { photography }\end{array}$ & $55-80$ & $421 / 615$ \\
\hline
\end{tabular}




\begin{tabular}{|c|c|c|c|c|c|c|}
\hline \multirow[b]{2}{*}{ Study (reference) } & \multicolumn{6}{|c|}{ Risk factor } \\
\hline & hyperopia & $\begin{array}{l}\text { blue/light iris } \\
\text { color }\end{array}$ & $\begin{array}{c}\text { cardiovascular } \\
\text { disease }\end{array}$ & hypertension & smoking & $\begin{array}{l}\text { sunlight } \\
\text { exposure }\end{array}$ \\
\hline Framingham (48) & & & + & $1.4(1.1-1.7)$ & & \\
\hline Malzman (115) & + & & $\mathrm{ns}^{\dagger}$ & $1.3\left(\mathrm{~ns}^{\dagger}\right)$ & $\mathrm{ns}^{\dagger}$ & \\
\hline Delaney (47) & + & $2.4(1.0-5.9)$ & & $6.1(2.1-18.5)$ & & \\
\hline Hyman (23) & + & $3.5(1.7-6.0)$ & $1.7(1.1-2.7)$ & & $1.2(0.8-1.9)$ & \\
\hline Blumenkranz (53) & $2.0(0.5-6.2)$ & $0.7(0.2-2.3)$ & $4.0(0.4-102)$ & $0.6(0.1-4.7)$ & $1.3(0.3-4.4)$ & \\
\hline Chesapeake Bay $(39,67,116)$ & & $1.1(0.6-2.0)$ & & & $0.6(0.4-1.1)$ & $1.4(1.0-1.9)^{\ddagger}$ \\
\hline Copenhagen $(14,40)$ & & $0.6(0.3-1.1)$ & 1.0 & $0.8\left(\mathrm{~ns}^{\top}\right)$ & $2.4(p<0.01)$ & \\
\hline Beaver Dam $(50,64,117)$ & & & $0.7(0.3-1.4)$ & $0.8(0.1-5.5)$ & $2.5(1.0-6.2)^{5}$ & $2.2(1.1-4.3)^{\rrbracket}$ \\
\hline EDCCSG (41) & $1.7(1.1-2.6)$ & $1.1(0.7-1.7)$ & $1.1(0.8-1.5)$ & $\mathrm{ns}^{\dagger}$ & $2.8(1.8-4.2)$ & $1.1(0.7-1.7)^{\mathbb{1}}$ \\
\hline Rotterdam $(54,65)$ & & & $2.5(1.4-4.5)^{1}$ & & $4.0(2.0-7.8)$ & \\
\hline
\end{tabular}

* Odds ratio's with $95 \%$ confidence intervals in parentheses.

† Not significant.

$\ddagger$ Blue light.

\$ Women.

Leisure time in summer.

If Atheroscierotic plaques in common carotid artery. 


\section{Chapter 2}

environmental factors may have played a role, the striking similarity of fundus appearances in each twin pair suggests an increased genetic susceptibility in at least some of the patients. Several studies focus on the familial aggregation of the whole range of ARM. A segregation analysis of data from the population-based Beaver Dam study (29), which included 546 sibships with at least two members, calculated sibling correlations for age-dependent ARM scores. The authors concluded that a single major gene could account for $55 \%$ and $57 \%$ of the total variability scores in the right and left eyes, respectively. Silvestri (30) studied familial aggregation of ARM in a case-control setting, cases being siblings of 36 affected patients and controls being siblings of 36 patients undergoing a cataract operation. Twenty of the 81 family members of the casegroup had ARM, while only one of the 78 family members of the control group was affected. This does suggest a strong genetic component, but these data were not age-adjusted and should, therefore, be evaluated with care.

\section{Ocular characteristics}

Iris colour. A protective effect of a dark pigmented iris on ARM has been suggested after a low prevalence of the disease was reported in black Africans $(31,32)$ and Australian Aborigines (32a). Cumulative light exposure may have a harmful effect on the photoreceptors and retinal pigment epithelium (33-37). A dark pigmented iris is possibly protecting the retina more against light exposure than a light coloured iris. Initially, two case-control studies reported a protective effect of a dark iris for $\operatorname{ARM}(23,38)$, but this was not confirmed in later studies (39-41) Recently, additional evidence for a protective effect of a dark iris was reported in a case-control study (42). Self-reported decrease of iris pigmentation during life was associated with ARM.

Refractive error. A possible association of hyperopia and ARM was first suggested by Maltzman et al. (43). Later, four case-control studies confirmed this finding $(23,38,41,44)$. There is, however, no generally accepted hypothesis explaining for the relation between ARM and hyperopia. Hyman pointed out that selection bias could have influenced that observation (23), because the control group may have overrepresented myopic subjects. The control group in another study (44) consisted of non-neovascular cases of ARM. The authors suggested that this control group may have comprised a larger proportion of cataract patients, which can result in myopia due to lens swelling and therefore may have led to a spurious association with hyperopia. Considering the probability of selection bias and the lack of a supportive theory, it is still doubtful whether an association between hyperopia and ARM exists.

\section{Cardiovascular disease}

One of the hypotheses for the pathogenesis of ARM that it is due to vascular disease affecting the choriocapillaris. This may result in decreased flow or passage 


\section{Epidemiology of age-related maculopathy}

of nutrients (45-47). The issue was examined in various ways, either by using blood pressure measurements or data concerning cardiovascular history.

Hypertension. Sperduto et al. reported a small and consistent association between ARM and hypertension as determined 25 years before in the Framingham Heart and Eye Study (48). The association was stronger with increasing duration of systemic hypertension. Vinding did not find an association between blood pressure levels and ARM in a four-year follow-up in the Copenhagen Heart Study (49). Other studies used blood pressure levels taken at the time of eye examination, and reported a positive association with increased systolic blood pressure $(15,41)$. Klein found no association with increased systolic blood pressure in Beaver Dam (50).

History of cardiovascular disease. Conflicting reports have been published about the association between ARM and a history of cardiovascular disease: several case-control studies found a positive association $(23,51,52)$, whereas others did not $(41,43,53)$.

Other cardiovascular risk factors. Increased total serum-cholesterol was associated with a strong increased risk of neovascular AMD in a large casecontrol study (41). This finding could not be confirmed in the Beaver Dam study (50) and Rotterdam studies (54). Further, a decreased risk was observed in women taking postmenopausal oestrogens (41). The role of oestrogens was also addressed in another case-control study which suggested a 5 times higher risk of ARM in women who had menopause before 45 years by oophorectomy (55). The possibility of selective survival cannot be ruled out in these cross-sectional studies.

\section{Hyperglycaemia and diabetes}

Hyperglycaemia has been reported to affect the choroidal circulation, Bruch's membrane and the pigment epithelium (56-61). A relation between hyperglycaemia and ARM has therefore been proposed. A number of case-control studies $(23,41,43,52,53)$ and two cross-sectional studies $(62,63)$ focused on this hypothesis. In only one study (52) a positive association of serum glucose levels and the mean area of drusen in females without diabetes was found. Recently, Klein et al. (63) reported no relation between glycosylated haemoglobin and ARM. In men with diabetes, aged 75 years or over, a higher frequency of neovascular AMD was found.

\section{Smoking}

An increased risk of ARM was first suggested by Paetkau et al. in male smokers (23a) and confirmed in several studies later $(23,41,49,64)$ although not uniformly $(39,62)$. The association with smoking was particularly present in neovascular AMD (64). Recently, this finding was confirmed in the Rotterdam Study (65). 


\section{Chapter 2}

\section{Light exposure}

The damaging effect of light exposure on the photoreceptors and retinal pigment epithelium has been reported in several experimental studies $(35,36)$. Possibly, long-term exposure to light is a factor in the pathogenesis of $\operatorname{ARM}(33,34)$. In a case-control study by Hyman et al. no significant association was reported between exposure to sunlight and ARM (23). In a study among fishermen (39), the ocular exposure was extensiveiy measured (66). No association between UV-A or UV-B exposure and ARM was observed. In an additional analysis, based on a small number of cases, a positive association was observed between blue light exposure and neovascular AMD (67). Cruickshanks et al. (68) reported a positive association between time spent outdoors in summer and the presence of drusen or pigmentary changes, as well as an inverse association with the use of hats or sunglasses in men. Further, they observed a positive association between the leisure time outdoors in summer and neovascular AMD. Recently, the Eye Disease Case-Control Study Group reported no association between light exposure and neovascular AMD (4I).

\section{Antioxidcht statuis}

The potenially damaging effect of cumulative light exposure on the retinal layers as described above, raised the question whether higher blood levels of antioxidants might protect against $\operatorname{ARM}(37,69)$. Evidence for possible protective effect of antioxidant nutrients emerged from basic research (70-76). A study based on the NHANES data revealed that a low intake of vitamin $A$ was associated with a higher risk of ARM (77) Newsome et al. suggested a beneficial effect of oral zinc on the natural course ARM (78). In another study, lower blood levels of carotenoids were observed in cases with neovascular AMD (79). Recently, West et al. (80) reported from a cross sectional study, that higher serum levels of $\alpha$ " tocopherol were associated with a decreased risk of ARM. In the latter studies the findings were suggestive for lower levels of vitamin $\mathrm{C}$ and $\mathrm{E}$ in cases with ARM.

\section{PROGNOSIS}

\section{Visual loss}

The risk of loss of visual acuity and the central visual field is the primary reason for concern about ARM. Several studies have shown that the disease usually affects both eyes of patients (11,81-84). Generally, severe visual loss is caused in these patients by a choroidal neovascular membrane and in a smaller amount of cases by atrophy of the retinal pigment epithelium involving the fovea $(11,23,85)$. The risk of visual loss in cases with bilateral drusen was reported in two followup studies. In the first study, Gass reported that nine of 49 cases developed severe visual loss in one eye during an average follow-up period of 4.9 years (11). In the other study of 71 patients by Smiddy et al. (86) severe visual loss due to 


\section{Epidemiology of age-related maculopathy}

neovascular disease occurred in seven eyes of six patients. Using life-table analysis, the five-year cumulative risk of visual loss was 12.7 percent. The interpretation of the results remains difficult, because both studies were based on prevalent cases with different duration of disease (87). Furthermore, the cases were obtained from specialized clinics which may have resulted in the selection of more severe cases. Therefore extrapolation of the results to a general population may be misleading.

ARM causes a severe visual handicap when both eyes are affected. The prognosis of the second eye in cases with unilateral neovascular AMD is therefore a matter of great concern. The issue was studied in several case-series $(11,82,83,88-90)$. The risk of second eye involvement is reported to be somewhere between 4 and 12 percent annually for the first three years (87).

\section{Prevention of visual loss}

The need for effective treatment of ARM is evident. The development of treatment techniques has mainly focused on suppression of subretinal neovascular membranes. For drusen, pigmentary changes and atrophic AMD, treatment is not available or quite experimental.

Laser photocoagulation has been used to occlude subfoveal neovascular membranes. Originally, treatment was limited to patients with a well demarcated choroidal neovascularization. Of further importance was the distance of the neovascular membrane to the foveola (91). Laser treatment of a subfoveal membrane leads to an immediate irreversible decline of visual acuity due to the destruction of the photoreceptors in the central fovea, but results after two years in a smaller scar and scotoma than no treatment (92). Estimations of the proportion of patients with neovascular AMD that may be treated for this reason, vary between 13 and 57 percent $(5,6,93,94)$. Unfortunately, more than half of the treated patients suffer from recurrences of choroidal neovascularization within five years (95). With the new technique of digital indocyanine green videoangiography the proportion of well demarcated neovascular membranes can be enlarged, possibly leading to better results in treatment $(96,97)$.

\section{NEW INTERVENTIONS}

Interferon. Systemic interferon alfa-2 has been used to treat vascular tumours $(98,99)$. It inhibits the growth of iris neovascularization in monkeys and even induces its regression (100). In vitro, interferon alfa inhibits vascular endothelial cell proliferation (101). After Fung suggested interferon as a potential treatment for neovascular AMD (102). Several case series (47,103-106), and one small randomized trial (108) have been reported. The results of the trial suggested a slower growth of the choroidal membrane in the treatment group at six months, the results of the case series were more difficult to interprete since the natural 


\section{Chapter 2}

course was not taken into account.

Radiotherapy. Low doses of ionizing radiation leads to regression of ocular haemangiomas (109) and of new vessel formation in wound healing $(110,111)$. The effect of radiotherapy on subretinal neovascularisation was investigated in a study (112) that reported higher visual acuity and smaller choroidal neovascular membranes in the treatment group after one year follow-up. The beneficial effect of radiation as well as the evaluation of the possible side effects on the ageing retina still need to be evaluated in other studies.

Antioxidants. As the above mentioned interventions are reserved to cases with neovascular AMD, alternatives to prevent the disease are under study. If one assumes that the cumulative damaging effect of radiant energy, such as sunlight, on the retinal layers is caused by the formation of free radicals, a beneficial effect of antioxidants may be expected. The effect of antioxidant therapy is expected to be small but of clinical relevance (113). Currently, treatments with vitamins $E$, $C$ and $B$-carotene, and zinc are being investigated in the Age Related Eye Disease Study, a multicentre randomized trial in the USA.

One small clinical trial suggested that oral suppletion of zinc may slow down the rate of visual decline over a two year period in patients with ARM (78). So far no other report was published on the issue and the need for further investigation is clear.

\section{CONCLISSIONS}

$\mathrm{ARM}$ is a major cause of severe visual impairment in western countries. The visual handicap has major consequences for the quality of life of patients and their relatives. In this paper we reviewed the epidemiologic findings concerning frequency, risk factors, and prognosis of the disease. The diagnosis ARM is still a matter of debate but recently progress is made by the development of classification systems for epidemiologic studies. The prevalence of ARM rises with age, the prevalence of end stages increases from 1 percent in subjects aged 65.74 to 5 percent in those aged 75-84 years. There is a clear need for incidence studies of ARM, and prospective follow-up studies of ARM and its risk factors. These are currently taking place in North America and Europe.

Risk factors for ARM have been studied in case-control studies and crosssectional studies. Except for age, no definite risk factors have been found. There are suggestions, however, that smoking, light exposure and low serum levels of beta-carotenoids may be associated with ARM. The origin of the association with smoking is not yet understood, but the association is interesting since smoking habits are potentially modifiable. The role of light exposure remains unclear; as yet, the possible harmful effect of light seems to be small. More extensive research is needed to evaluate the magnitude of the genetic component and mode of inheritance. Localization of the genes will lead to a better understanding of the 


\section{Epidemiology of age-related maculopathy}

underlying causes of ARM, and identification of family members at risk will provide the basis for future therapeutic and preventative interventions.

The visual prognosis of patients with drusen or pigmentary changes is fair in general, and patients with atrophic AMD usually retain useful vision for years. The prognosis is worse however in patients with unilateral and bilateral neovascular AMD. Population-based studies are needed to provide a better estimate on this issue. Currently, there is no effective treatment for the disease except for a selected group of patients with neovascular AMD, in which treatment with laser photocoagulation has some benefits. Promising interventions with radiotherapy or interferon are currently being investigated which may have beneficial consequences for patients who are not eligible for laser treatment. The effect of interferon on neovascular AMD needs to be studied in larger prospective randomized trials. Future studies will reveal the effect of antioxidant suppletion in preventing or slowing down the disease process. 


\section{Chapter 2}

\section{REFERENCES}

1. Kahn HA, Moorhead HB: Statistics on blindness in the Model Reporting Areas 1969-1970. United States Department of Health, Education and Welfare Publication No. (NIH) 73-427. Washington, DC, US Government Printing Office, 1973.

2. Leibowitz H, Krueger DE, Maunder LR, et al. The Framingham Eye Study Monograph; an ophthalmological and epidemiological study of cataract, glaucoma, diabetic retinopathy, macular degeneration, and visual acuity in a general population of 2631 adults, 1973-1977. Surv Ophthalmol $1980 ; 24: 335-610$.

3. National Advisory Eye Council. Report of the Retinal and Choroidal Disease Panel: Vision Research: A National Plan: 1983-1987. Washington, DC: US Dept of Health and Human Services; 1984. NIH publication 83. 2471.

4. Ghafour IM, Allan D, Foulds WS. Common causes of blindness and visual handicap in the west of Scotland. Br J Ophthalmol 1983; 67:209-13.

5. Bressler NM, Bressler SB, Gragoudas ES. Clinical characteristics of choroidal neovascular membranes. Arch Ophthalmol 1987;105:209-13.

6. Freund KB, Yanuzzi LA, Sorenson JA. Age-related macular degeneration and choroidal neovascularization. Am J Ophthalmol 1993;115:786-91.

7. Bressler NM, Bressler SB, West SK, et al. The grading and prevalence of macular degeneration in Chesapeake Bay watermen. Arch Ophthalmol 1989;107:847-52.

8. Klein R, Davis MD, Magli YL, et al. The Wisconsin Age-related Maculopathy. Grading System. Ophthalmology 1991;98:1128-34.

9. The International Age-Related Maculopathy Study Group. An international classification system for ARM. Surv Ophthalmol (in press).

10. Klein R, Klein BEK, Linton KLP: Prevalence of age-related maculopathy. The Beaver Dam Eye Study. Ophthalmol 1992;99:933-42.

11. Gass JDM: Drusen and disciform macular detachment and degeneration Trans Am Ophthalmol Soc 70:409-436.idem: Arch Ophth 1973;90:206-17.

12. Ryan SJ, Mittl RN, Maumenee AE: The disciform response: an historical perspective. Graefes Arch Clin Exp Ophthalmol 1980;215:1-20.

13. Martinez GS, Campbell AJ, Reinken J, et al. Prevalence of ocular disease in a population study of subjects 65 years old and older. Am J Ophthalmol 1982;94:181-9.

13a: Gibson JM, Rosenthal AR, Lavery J. A study of the prevalence of eye disease in the elderly in an English community. Trans Ophthalmol Soc UK 1985;104:196-202.

14. Vinding $T$. Age-related macular degeneration. Macular changes, prevalence and sex ratio. Acta Ophthalmol 1989;67;609-16.

15. Klein BEK, Klein R. Cataracts and macular degeneration in older americans. 


\section{Epidemiology of age-related maculopathy}

Arch Ophthalmol 1982;100:571-3.

16. Rothman KJ. Modern Epidemiology. Little, Brown and Company. 1986.

17. Hutchinson J, Tay W: Symmetrical central chorio-retinal disease in senile persons. Roy Lond Ophthal Hosp Rep 1875;8:231-44.

18. Elwyn $\mathrm{H}$. The heredodegenerations and heredoconstitutional defects of the retina. Arch Ophthalmol 1955;53:619-33.

19. Klien B. The heredodegeneration of the macula lutea diagnostic and differential diagnostic considerations and a histopathologic report. Am J Ophthalmol 1950;33:371-9.

20. Kril! AL, Deutman AF. Dominant macular degenerations, the cone distrophies. Am J Ophthalmol 1972;73:353-69.

21. Deutman AF, Jansen LMAA: Dominantly inherited drusen of Bruch's membrane. Br J Ophthalmol 1970;54:373-82.

22. Piguet B, Wells JA, Palmvang IB, et al. Age-related Bruch's membrane change: a clinical study of relative role of heredity and environment. B J Ophthalmol 1993;77:400-3.

23a. Paetkau ME, Boyd TA, Grace M, Bach-Mills J, Winship B. Senile disciform macular degeneration and smoking. Can J Ophthalmol 1978;13:67-71.

23. Hyman LG, Lilienfeld AM, Ferris FL, et al. Senile macular degeneration: a case control study. Am J Epidemiol 1983;118:213-27.

24. Linton $\mathrm{KL}$, Klein $\mathrm{BE}, \mathrm{K}$ lein $\mathrm{R}$. The validity of self-reported and surrogate-reported cataract and age-related macular degeneration in the Beaver Dam Eye Situdy. Am J Epidemiol 1991;134:1438-46.

25. Melrose MA, Magargal LE, Lucier AC. Identical twins with subretinal neovascularization complicating senile macular degeneration. Ophthalmic Surg 1985;16:648-51.

26. Meyer KT, Heckenlively JR, Spitznas $M$, et al. Dominant retinitis pigmentosa. A clinicopathologic correlation. Ophthalmology 1982;89:1414-24.

27. Dosso AA, Bovet J. Monozygotic twin brothers with age-related macular degeneration. Ophthalmologica 1992;205:24-8.

28. Klein ML, Mauldin WM. Stoumbos VD. Heredity and age-related macular degeneration. Observations in monozygotic twins. Arch Ophthalmol 1994;112:932-7.

29. Heiba IM, Elston RC, Klein BEK, et al. Sibling correlations and segregation analysis of age-related maculopathy: The Beaver Dam Eye Study. Genet Epidemiol 1994;11:51-67.

30. Silvestri $G$, Johnston $\mathrm{PB}$, Hughes $\mathrm{AE}$. Is genetic predisposition an important risk factor for age-related macular degeneration? Eye 1994;8:564-8.

31. Chumbley LC. Impressions of eye diseases among Rhodesian blacks in Mashonaland. S Afr Med J 1977;52:316-8.

32. Gregor Z, Joffe L. Senile macular changes in the black African. Br J Ophthalmol 1978;62:547-50. 


\section{Chapter 2}

32a. Taylor HR. Prevalence and causes of blindness in Australian Aborigines. Med J Aust 1980;1:71-6.

33. Tso MOM, Woodford BJ. Effects of photic injury on the retinal tissues. Ophthalmology 1983;90:953-63.

34. Mainster MA, Ham WT, Delori FC. Potential retinal hazards. Instrument and environmental light sources. Ophthalmology 1983;90;927-32.

35. Ham WT, Muller HA. The photopathology and nature of the blue light and near-UV retinal lesions produced by lasers and other optical sources. Laserapplications in medicine and biology (1989). Ed. Wolbarhst. Plenum, New York.

36. Noell WK. Possible mechanisms of photoreceptor damage by light in mammalian eyes. Vis Res 1980;20:1163-71.

37. Young RW. Solar radiation and age-related macular degeneration. Surv Ophthalmol 1988;32:252-69.

38. Weiter JJ, Delori FC, Wing GL, et al. Relationship of senile macular degeneration to ocular pigmentation. Am J Ophthalmol 1985;99:185-7.

39. West SK, Rosenthal FS, Bressler NM, et al. Exposure to sunlight and other risk factors for age-related macular degeneration. Arch Ophthalmol 1989;107:875-9.

40. Vinding T. Pigmentation of the eye and hair in relation to age-related macular degeneration. Acta Ophthalmol 1990;68:53-8.

41. The Eye Disease Case-Control Study Group: Risk factors for neovascular age-related macular degeneration. Arch Ophthalmol 1992;110:1701-8.

42. Holz FG, Piquet B, Minassian DC, et al. Decreasing Stromal iris pigmentation as a risk factor for age-related macular degeneration. Am $\mathrm{J}$ Ophthalmol 1994;117:19-23.

43. Maltzman BA, Mulvihill MN, Greenbaum A. Senile macular degeneration and risk fators: a case-control study. Ann Ophthalmol 1979;1197-201.

44. Sandberg MA, Tolentino MJ, Miller S, et al. Hyperopia and neovascularization in age-related macular degeneration. Ophthalmology 1993;100:1009-13.

45. Verhoeff FH, Grossman HP. Pathogenesis of disciform degeneration of the macula. Arch Ophthalmol 1937;18:561-85.

46. Gass JDM: Pathogenesis of disciform detachment of the neuroepithelium III Senile disciform macular degeneration. Am J Ophthalmol 1967;63:573-711.

47. Kornzweig AL. Changes in the choriocapilaris associated with senile macular degeneration. Ann Ophthalmol 1977;9:753-64.

48. Sperduto RD, Hiller R: Systemic hypertension and age-related maculopathy in the Framingham Study. Arch Ophthalmol 1986;104:216-9.

49. Vinding T, Appleyard M, Nyboe J. Risk factor analysis for atrophic and exudative age-related macular degeneration. Acta Ophthalmol 1992;70:6672 .

50. Klein R, Klein BEK, Franke T. The relationship of cardiovascular disease 


\section{Epidemiology of age-related maculopathy}

and its risk factors to age-related maculopathy. Ophthalmology 1993;100:406-14.

51. Delaney WV, Oates RP. Senile macular degeneration: a preliminary study. Ann Ophthalmol 1982;14:21-4.

52. Vidaurri JS, Pe'er J, Halfon ST, Halperin G, et al. Association between drusen and some risk factors for coronary artery disease. Ophthalmologica 1984;188:243-7.

53. Blumenkranz MS, Russell SR, Robey MG, et al. Risk factors in age-related maculopathy complicated by choroidal neovascularization. Ophthalmology $1986 ; 93 ; 552-8$.

54. Vingerling JR, Dielemans I, Bots ML, et al. Age-related macular degeneration is associated with atherosclerosis: The Rotterdam Study. Am J Epidemiol (accepted).

55. Vingerling JR, Dielemans I, Witteman JCM, et al. Is macular degeneration associated with early menopause? B M J (in press).

56. Hidayat AA, Fine BS. Diabetic choroidopathy. Light and electron microscopic observations of seven cases. Ophthalmology 1985;92:512-22.

57. Fryczkowski AW, Sato SE, Hodes BL. Changes in the diabetic choroidal vasculature: scanning electron microscopy findings. Ann Ophthalmol 1988;20:299-305.

58. Vinores SA, Campochiaro PA, May EE, et al. Progressive ultrastructural damage and thickening of the basement membrane of the retinal pigment epithelium in spontaneously diabetic BB rats. Exp Eye Res 1988;46:545-58.

59. Miceli MV, Newsome DA. Cultured retinal pigment epithelium cells from doncrs with type I diabetes show an altered insulin response. Invest Ophthalmol Vis Sci 1991;32:2847-53.

60. Chaikrabarti S, Prashar S, Sima AAF. Augmented polyol pathway activity and retinal pigment epithelial permeability in the diabetic BB rat. Diabetes Res Clin Pract 1990;8:1-11.

61. Marano CW, Matschinsky FM. Biochemical manifestations of diabetes mellitus in microscopic layers of the cornea and retina. Diabetes Metab Rev 1989;5:1-15.

62. Kahn HA, Leibowitz HM, Ganley JP, et al. The Framingham Eye Study II. Association of ophthalmic pathology with single variables previously measured in the Framingham Heart Study. Am J Epidemiol 1977;106:33-41.

63. Klein R, Klein BEK, Moss SE. Diabetes, hyperglycemia, and age-related maculopathy. The Beaver Dam Eye Study. Ophthalmology 1992;99:152734.

64. Klein R, Klein BE, Linton KL, DeMets DLA. The Beaver Dam Eye Study: the relation of age-related maculopathy to smoking. Am J Epidemiol $1993 ; 137: 190-200$.

65. Vingerling JR, Dielemans I, Hofman A, et al. Age-related macular degeneration and smoking: The Rotterdam Study. (submitted) 


\section{Chapter 2}

66. Rosenthal FS, West SK, Muñoz B, et al. Ocular and facial skin exposure to ultraviolet radiation in sunlight: a personal exposure model with application a worker population. Health Physics. 1991;61:77-86.

67. Taylor HR, Muñoz B, West S, et al. Visible light and risk of age-related macular degeneration. Trans Am Ophthalmol Soc 1990;88:163-78.

68. Cruickshanks KJ, Klein R, Klein BEK. Sunlight and age-related macular degeneration. The Beaver Dam Eye Study. Arch Ophthalmol 1993;111:5148.

69. Sperduto RD, Ferris FL, Kuriny N. Do we have a nutritional treatment for age related cataract or macular degeneration? Arch Ophthalmol 1990;108:1403-5.

70. Katz ML, Parker KR, Handelman GJ, et al. Effects of antioxidant nutrient deficiency on the retina and pigment epithelium of albino rats: a light and electron microscopic study. Exp Eye Res 1982;34:339-9.

71. Hayes KC. Retinal degeneration in monkeys induced by deficiencies of vitamin $\mathrm{E}$ or A. Invest Ophthalmol 1974;13:499m510.

72. Organisciak DT, Wang $\mathrm{HM}, \mathrm{Li} \mathrm{Z}$, et al. The protective effect of ascorbate in retinal light damage of rats. Invest Ophthalmol Vis Sci 1985;26:1580-88.

73. Tso MO, Woodford BJ, Lam KW. Distribution of ascorbate in normal primate retina and after photic injury: a biochemical, morphological correlated study. Curr Eye Res 1984;3:165-74.

74. Ham WT, Mueller HA, Ruffolo JJ, et al. Basic mechanisms underlying the production of photochemical lesions in the mammalian retina. Curr Eye Res 1984;3:165-74.

75. Liles MR, Newsome DA, Oliver PD. Antioxidant enzymes in the aging human retinal pigment epithelium. Arch Ophthalmol 1991;109:1285-8.

76. Oliver PD, Tate DJ Jr, Newsome DA. Metallothionein in human retinal pigment epithelial cells: expression, induction and zinc uptake. Curr Eye Res 1992;11:183-88.

77. Goldberg J, Flowerdew G, Smith E, et al. Factors associated with age-related macular degeneration. An analysis of datafrom the first National Health and Nutrition Examination Survey. Am J Epidemiol 1988; 128:700-10.

78. Newsome DA, Swartz $\mathrm{M}$, Leone $\mathrm{NC}$, et al. Oral zinc in macular degeneration. Arch Ophthalmol 1988;106:192-8.

79. The Eye Disease Case-Control Study Group. Antioxidant status and neovascular age-related macular degeneration. Arch Ophthalmol 1993;111:104-9.

80. West SK, Vitale S, Hallfrish J, et al. Are antioxidants or supplements protective for age-reltaed macular degeneration? Arch Ophthalmol 1994;112:222-7.

81. Chandra SR, Gragoudas ES, Friedman E, et al. Natural history of disciform degeneration of the macula. Am J Ophthalmol 1974;78:579-82. 


\section{Epidemiology of age-related maculopathy}

82. Gregor Z, Bird AC, Chisholm IH. Senile disciform macular degeneration in the second eye. Brit J Ophthalmol 1977;61:141-7.

83. Strahlman ER, Fine SL, Hillis A. The second eye of patients with senile macular degeneration. Arch Ophthalmol 1983;101:1191-3.

84. Bressler SB, Bressler NM, Fine SL, et al. Natural course of choroidal neovascular membranes within the foveal avascular zone in senile macular degeneration. Am J Ophthalmol 1982;93:157-63.

85. Ferris FL, Fine SL, Hyman L, Age-related macular degeneration and blindness due to neovascular maculopathy, Arch Ophthalmol 1984;102:1640-2.

86. Smiddy WE, Fine SL. Prognosis of patients with bilateral macular drusen. Ophthalmology 1984;91:271-6.

87. Roy M, Kaiser-Kupfer M. Second eye involvement in age-related macular degeneration: A four-year prospective study. Eye 1990;4:813 8.

87. Bressler NM, Bressler SB, Fine SL. Age-related macular degeneration. Surv Ophthalmol 1988;32:375-413.

88. Teeters VW, Bird AC. The development of neovascularization of senile disciform macular degeneration. Am J Ophthalmol 1973;76:1-18.

89. Bressler SB, Maguire MG, Bressler NM, et al. Relationship of drusen and abnormalities of the retinal pigment epithelium to the prognosis of neovascular macular degeneration. Arch Ophthalmol 1990; 108:1442-7.

90. Baun $O$, Vinding T, Krogh E. Natural course in fellow eyes of patients with unilateral age-related exudative maculopathy. Acta Ophthalmol Copenh 1993;71:398-401.

91. Argonlaser photocoagulation for senile macular degeneration. Results of a randomized trial. Arch Ophthalmol 1982;100:912-8.

92. Macular Photocoagulation Study Group. Laser photocoagulation of subfoveal neovascular lesions in age-related macular degeneration. Results of a randomized trial. Arch Ophthalmol 1991;109:1220-31.

93. Berkow JW. Subretinal neovascularisation in senile macular degeneration. An. J Ophthalmol 1984;97:143-7.

94. Grey RHB, Bird AC, Chisholm IH. Senile macular degeneration. Features indicating suitability for photocoagulation. $\mathrm{Br} \mathrm{J}$ Ophthalmol 1979;63:85-9.

95. Macular Photocoagulation Study Group. Argon laser photocoagulation for neovascular maculopathy. Five-year results from randomized clinical trials. Arch Ophthalmol 1991;109:1109-14.

96. Yannuzzi LA, Slakter JA, Sorenson JA, et al. Digital indocyanine green videoangiography and choroidal neovascularization. Retina 1991;12:191-

97. Destro $\mathrm{M}$, Puliafito $\mathrm{CA}$. Indocyanine green videoangiography of choroidal neovascularization. Ophthalmology 1989;96:846-

98. White CW, Sondheimer HM, Crouch EC, et al. Treatment of pulmonary hemangiomatosis with recombinant interferon alfa $2 a$. $N$ Eng $J$ Med. 1989;320:1197-200. 


\section{Chapter 2}

99. Orchard PJ, Smith CM III, Woods WG, et al. Treatment of hemangioendotheliomas with alfa interferon. Lancet 1989;ii:565-67.

100. Miller JW, Stinson WG, Folkman J. Regression of experimental iris neovascularization with systemic alfa-interferon. Ophthalmology 1993;100:9-14.

101. Feldman D, Goldstein AL, Cox DC, et al. Cultured human endothelial cells treated with recombinant leukocyte $\mathrm{A}$ interferon: tuboreticular inclusion formation, antiproliferative effect and 2',5' oligoadenylate synthetase induction. Lab Invest 1988;58:584 -9.

102. Fung WE. Interferon alfa-2a for the treatment of age-related macular degeneration. Am J Ophthalmol 1991;112:349-50.

103. Loughman MS, Heriot WJ, O'Day J. Treatment of subfoveal choroidal neovascular membrane with systemic interferon alpha-2a. Aust $\mathrm{N} \mathrm{Z} \mathrm{J}$ Ophthalmol 1992;20:173-5.

104. Engler CB, Sander B, Koefoed P, et al. Interferon alpha-2a treatment of patients with subfoveal neovascular macular degeneration. A pilot investigation. Acta Ophthalmol Copenh 1993;71:27-31.

105. Lewis $M L$, Davis $J$, Chuang $E$. Interferon alfa-2a in the treatment of exudative age-related macular degeneration. Graefes Arch Clin Exp Ophthalmol 1993;231:615-8.

106. Gillies MC, Sarks JP, Beaumont PE, et al. Treatment of choroidal neovascularization in age-related macular degeneration with interferon alfa$2 \mathrm{a}$ and alfa-2b. Br J Ophthalmol 1993;77:759-65.

107. Chan CK, Kempin SJ, Noble SK, et al. The treatment of choroidal neovascular membranes by alpha interferon. An efficacy and toxicity study. Ophthalmology 1994;101:289.300.

108. Poliner LS, Tornambe PE, Michelson PE, et al. Interferon alpha-2a for subfoveal neovascularization in age-related macular degeneration. Ophthalmology 1993;100:1417-24.

109. Plowman PN, Harnett AN. Radiotherapy in benign orbital disease. I. Complicated ocular angiomas. Br J Ophthalmol 1991;109:1220-31.

110. Chakravarthy U, Gardiner TA, Archer DB, et al. A light microscopic and autoradiographic study of non-irradiated and irradiated ocular wounds. Curr Eye Res 1989;8:337-48.

111. Chakravarthy $\mathrm{U}$, Biggart $\mathrm{JH}$, Gardiner $\mathrm{TA}$, et al. Focal irradiation of perforating eye injuries: minimum effective dose and optimum time of irradiation. Curr Eye Res 1989;8:1241-50.

112. Chakravarthy U, Houston RF, Archer DB. Treatment of age-related subfoveal neovascular membranes by teletherapy: a pilot study. $\mathrm{Br} \mathrm{J}$ Ophthalmol 1993;77:265-73.

113. Seddon JM, Hennekens CH. Vitamins, minerals, and macular degeneration. Promising but unproven hypothesis. Arch Ophthalmol 1994;112:176-79.

114. Jonasson F, Thordarson $\mathrm{K}$. Prevalence of ocular disease and blindness in a 


\section{Epidemiology of age-related maculopathy}

rural area in the eastern region of Iceland during 1980 through 1984. Acta Ophthalmol 1987;65(suppl);40-3.

115. Vingerling JR, Dielemans I, Hofman A, et al. The prevalence of age-related maculopathy in the Rotterdam Study. Ophthalmology 1995;102:205-10.

116. Malzman BA, Mulvihill MN, Greenbaum A. Senile macular degeneration and risk factors: a case-control study. Ann Ophthalmol 1979;1197-201. 


\section{AN INTERNATIONAL CLASSIFICATION AND GRADING SYSTEM FOR AGE-RELATED MACULOPATHY AND AGE-RELATED MACULAR DEGENERATION}

Age-related maculopathy (ARM) is a degenerative disorder of the central area of the retina (the macula) often associated with visual impairment which is more frequent after 65 years of age. The disciform variant of this disorder was first described in 1875 (13). In 1885, Haab labelled the disease senile macular degeneration. (6). Over the years there have been many different names and expressions for ARM. $(1,14)$.

While ARM has been described for over 100 years, there is neither a standard agreement on the definition of specific lesions nor a generally accepted classification system. Clinical and epidemiological studies of ARM have used different diagnostic tools such as perimetry, dark adaptation, contrast sensitivity, ophthalmoscopy, fundus reflectometry, scanning laser ophthalmoscopy, biomicroscopy, black-and-white fundus photography, colour fundus photography with white, blue or red-free light, angiography with fluorescein or indocyanine green, and histology or electron microscopy. These approaches have often resulted in different definitions and severity scales. There is also inconsistency in the interpretation of histological and clinical manifestations of the early stage of ARM. This has limited comparisons of findings among clinical and epidemiological studies.

Various definitions of ARM used in earlier epidemiological studies, are given in Table 1. Some studies required a visual acuity component in their definition of $\operatorname{ARM}(4,11,12,16)$ whereas others did not $(2,7,9)$. In more recent studies of ARM $(2,7,9)$, photographic standards of various abnormalities have been used in the grading of fundus photographs. The age limits varied widely in these studies from 1 to 98 years (Table 1). To facilitate comparison of data among studies of ARM there is a need for development of commonly used methods to detect, grade and define this disease.

\section{RATIONALE}

There are few epidemiological studies describing the natural history and risk factors for ARM but a number of such studies are currently in progress or are being planned. These studies are designed to examine the relationship of early morphological changes, such as hard drusen, soft distinct drusen, and increased or decreased retinal pigment epithelial (RPE) pigmentation to the development of late stages of the disease and to visual outcomes. It would be of benefit to have 


\section{Classification of age-related maculopathy}

Table 1. Definitions of and age limits in ARM used in population based studies.

Framingham Eye Study (11):

- An eye was diagnosed as having senile macular degeneration if its visual acuity was $20 / 30$ or worse and the ophthalmologist designated the etiology of changes in the macula or posterior pole as senile. Age limits $52-85$ years.

National Health and Nutrition Eye Study (4):

- Age-related macular degeneration: loss of macular reflex, pigment dispersion and clumping, and drusen associated with visual acuity of $20 / 25$ or worse believed to be due to this disease.

- Age-related disciform macular degeneration: choroidal haemorrhage and connectivetissue proliferation between retinal pigment epithelium and Bruch's membrane causing an elevation of the foveal retina (this condition should be differentiated from disciform degenerations of other causes, eg, histoplasmosis, toxoplasmosis, angioid streaks, and high myopia).

- Age-related circinate macular degeneration: perimacular accumulation of lipoid material within the retina. Age limits: 1-74 years.

Gisborne Study (12):

- Senile macular degeneration: when the visual acuity in the affected eye was $6 / 9$ $(20 / 30)$ or worse and senile macular degeneration was identified as the probable cause of this visual loss. Age: $\geq 65$ years

\section{Copenhagen Study (16):}

- Age-related macular degeneration (AMD): Best corrected visual (Snellen) acuity (including pin hole improvement) of 6/9 or less, explained by age related morphologic changes of the macula.

- Atrophic (dry) changes: disarrangement of the pigment epithelium (atrophy/clustering) and/or a small cluster of small drusen and/or medium drusen and/or large drusen and/or pronounced senile macular choroidal atrophy/sclerosis without general fundus involvement.

- Exudative (wet) changes: elevation of the neurosensory retina and/or the pigment epithelium and/or haemorrhages, and/or hard exudates and/or fibrovascular tissue.

- Age related macular changes without visual impairment (AMCW) is defined as similar morphological lesions but without visual deterioration. Age limits: 60-80 years. 


\section{Chapter 3}

Chesapeake Bay Study (2):

- No specific overall definition, Geographic atrophy: an area of well-demarcated atrophy of the RPE in which the overlying retina appeared thin. Exudative changes: choroidal neovascularization, detachments of the RPE, and disciform scarring. Grading of AMD in 4 grades:

- 4: geographic atrophy of the RPE or exudative changes.

- 3: grade 4 or eyes with large or confluent drusen or eyes with focal hyperpigmentation of the RPE.

- 2: grade 4 or 3 or eyes with many small drusen $(\geq 20)$ within $1500 \mu \mathrm{m}$ of the foveal centre.

- 1: Grade 4, 3, or 2 or eyes with at least five small drusen within $1500 \mu \mathrm{m}$ of the foveal centre or at least ten small drusen between 1500 and $3000 \mu \mathrm{m}$ from the foveal centre. No visual acuity included. Age limits: $\geq 30$ years

Beaver Dam Eye Study (9):

- Early age-related maculopathy was defined as the absence of signs of late agerelated maculopathy as defined below and as the presence of soft indistinct or reticular drusen or by the presence of any drusen type except hard indistinct, with RPE degeneration or increased retinal pigment in the macular area.

- Late age-related maculopathy was defined as the presence of signs of exudative agerelated macular degeneration or geographic atrophy. The grade assigned for the participant was that of the more severely involved eye. No visual acuity included. Age limits: $43-86$ years.

Rotterdam Study (7):

- All ARM changes had to be within a radius of $3000 \mu \mathrm{m}$ of the foveola. No definition of early ARM but separate prevalence figures for drusen and retinal pigment epithelial hyperpigmentations or hypopigmentations attributable to age-related causes.

- Late ARM (is similar to AMD): the presence of atrophic AMD (well demarcated area of RPE atrophy with visible choroidal vessels) and/or neovascular AMD (serous and/or haemorrhagic RPE detachment, and/or subretinal neovascular membrane and/or haemorrhage, and/or periretinal fibrous scar) attributable to age-related causes. In a participant the most severely involved eye was taken for the analysis. No visual acuity included. Age limits: $\geq 55$ years. 


\section{Classification of age-related maculopathy}

grading systems and definitions for ARM similar to the Airlie House classification scheme for diabetic retinopathy, that would permit the possibility for comparison between studies in the future (3). This paper describes the results of a series of meetings among six groups involved in epidemiological studies of ARM in order to develop a core grading system using colour stereoscopic fundus transparencies to detect and define ARM. As more data are collected from studies presently under way or other studies which arise in the future, it is expected that further refinements will be made to the grading system. This is due to the fact that a severity scale will be required for long-term studies of the natural history of this disease in large populations to establish rates of progression successfully.

\section{METHODS}

In the development of a grading classification for ARM, we have used the anatomical definition of the macula, defining it as that part of the retina centred on the foveola in which the ganglion cell layer is more than one cell in thickness, that has an approximate diameter of $5.5 \mathrm{~mm}(8)$. For descriptive purposes the inner macula is defined as the area within a circle, centred on the foveola, of diameter $3000 \mu \mathrm{m}$, i.e. approximately two disc diameters across (Figure 1). The outer macula is defined as the area between the inner macula (diameter $3000 \mu \mathrm{m}$ ) and a circle with a diameter of $6000 \mu \mathrm{m}$.

We defined ARM primarily on the basis of morphological changes seen on, preferentially stereoscopic, colour fundus transparencies and defined its presence as "age-related" by inclusion of age (e.g. $\geq 50$ years). Visual acuity is not a criterion for the presence or absence of ARM. Other historical or clinical information, if available is used prior to defining a lesion as one associated with ARM.

It is proposed to name all signs of age-related macular changes as age-related maculopathy (ARM) and to classify them by presumed order of severity. Further classification of severity using this system will depend on findings from large population-based studies and clinical trials. 


\section{Chapter 3}

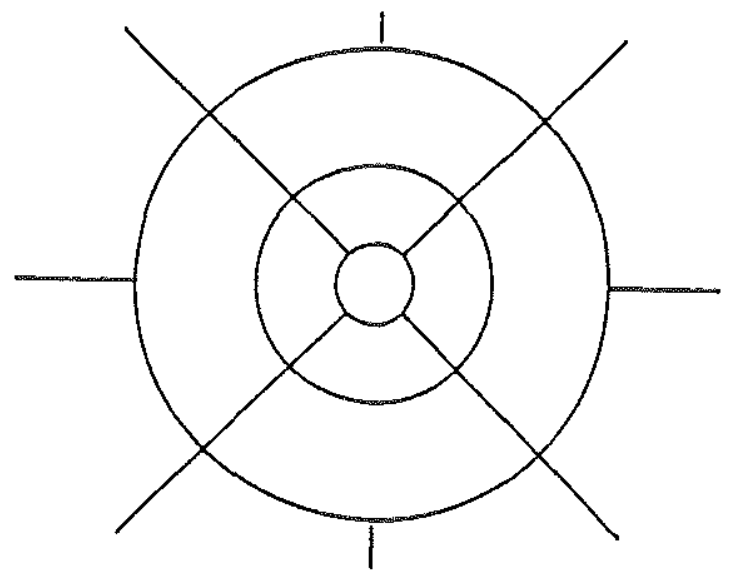

Figure 1. Standard grid for ARM classification. The circles should be reduced on a transparent sheet, according to the magnification of the fundus camera used, so that they have approximate diameters of 1000,3000 and $6000 \mu \mathrm{m}$ respectively, in the fundus of an average eye. These circles represent respectively the central, middle and outer subfield. The mid-peripheral subfield is outside the outer circle within field 2. (3). The spokes may be of help in centring the grid on the macula. Published courtesy of Ophthalmology 1991;98:1128-34. 


\section{Classification of age-related maculopathy}
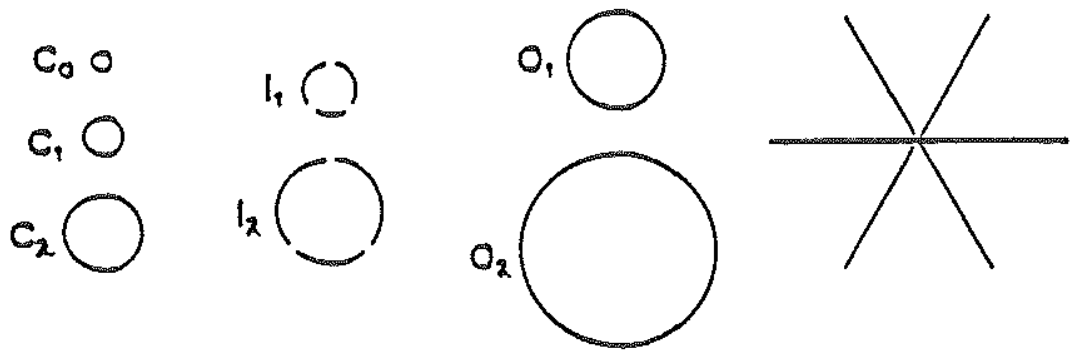

Figure 2. Standard circles for grading of ARM related fundus changes. The circles $C_{0} C_{1}, C_{2}, C_{3}$, and $C_{4}$ are used for all subfields. The circles should be reduced on a transparent sheet, according to the magnification of the fundus camera used, so that they have approximate diameters in the average fundus of $63 \mu \mathrm{m}, 125 \mu \mathrm{m}, 175 \mu \mathrm{m}, 250 \mu \mathrm{m}$ and $500 \mu \mathrm{m}$. Note that the diameter of circle $C_{4}$ is half the diameter of the inner circle on figure 1 . All circles may be used for estimation of drusen size. Circle $C_{0}$ differentiates small from large drusen. Circles $C_{1}$ and $C_{2}$ may be used for grading area involved by increased pigmentation or $R P E$ depigmentation, circle $C_{2}$ for minimum area of geographic atrophy, and $C_{3}$ and $C_{4}$ for area of geographic atrophy or neovascular AMD. The spokes facilitate locating the centre point and estimating the size of lesions. 


\section{Chapter 3}

\section{DEFINITIONS}

ARM is a disorder of the macular area of the retina, most often clinically apparent after 50 years of age, characterized by any of the following primary items, without indication that they are secondary to another disorder (e.g., ocular trauma, retinal detachment, high myopia, chorioretinal infective or inflammatory process, choroidal dystrophy, etc):

- Discrete whitish-yellow spots identified as "drusen" which are external to the neuroretina or the RPE. They may be soft and confluent, most often with indistinct borders. Small, hard drusen, usually present in eyes with as well as those without ARM, do not of themselves characterize the disorder.

- Areas of increased pigment or hyperpigmentation (in the outer retina or choroid).

- Areas of depigmentation or hypopigmentation of the RPE, most often more sharply demarcated than drusen, without any visibility of choroidal vessels.

- The late stages of ARM, that will be called age-related macular degeneration (AMD). Thus, AMD is a late stage of ARM and includes both "dry" and "wet" AMD.

Dry AMD or geographic atrophy is characterized by:

- Any sharply delineated roughly round or oval area of hypopigmentation or depigmentation or apparent absence of the RPE in which choroidal vessels are more visible than in surrounding areas that must be at least $175 \mu \mathrm{m}$ in diameter $\left(\geq \mathrm{C}_{2}\right.$; Figure 2 ) on the colour slide (using a $30^{\circ}$ or $35^{\circ}$ camera).

- Wet AMD is also called "neovascular" AMD, "disciform" AMD, or "exudative" AMD and is characterized by any of the following:

- RPE detachment(s), which may be associated with neurosensory retinal detachment, associated with other forms of ARM .

- Subretinal or sub-RPE neovascular membrane(s)

- Epiretinal (with exclusion of idiopathic macular puckers), intraretinal, subretinal, or sub pigment epithelial scar/glial tissue or fibrin-like deposits.

- Subretinal haemorrhages that may be nearly black, bright red, or whitish-yellow and that are not related to other retinal vascular disease. (Haemorrhages in the retina or breaking through it into the vitreous may also be present).

- Hard exudates (lipids) within the macular area related to any of the above, and not related to other retinal vascular disease.

Because geographic atrophy and neovascular AMD may be different manifestations of the disorder and may have different causes, it may be useful to separate them, especially when examining relationships to risk factors. Rarely neovascular AMD may develop in an area of geographic atrophy. 


\section{Classification of age-related maculopathy}

\section{PHOTOGRAPHY AND FILM PROCESSING}

Preferentially colour $30^{\circ}$ or $35^{\circ}$ stereoscopic transparencies of a modified field 1 (centred on the temporal edge of the disc) and field 2 (centred on the fovea) and an optional modified field 3 (temporal to the fovea but including the fovea in the nasal edge) are taken after pupillary dilation. (3). Inclusion of modified fields 1 and 3 may help the grader detect subtle drusen, changes in pigmentation, and other lesions associated with ARM.

Kodachrome ASA 25 or 64 film or equivalent should be used. If other equivalent film types are used, they should have similar colour and grain characteristics and similar stability over time. Other films such as Ektachrome 100 may be used. However, because in the past Ektachrome has been less stable over time than Kodachrome, it may be less appropriate for a long-term study. Faster films with higher ASA rating may appear more "grainy". Films which have too much "red" or "brown" in them may cause problems in grading some lesions associated with ARM such as retinal pigment epithelium hypopigmentation. The film processor should be carefully chosen and if possible the same processor and process should be used throughout an entire study. Colour shifts in the processing may cause problems in grading of some lesions associated with ARM. The same film type, (preferentially bought from the same lot and frozen at the beginning of a study), may minimize changes in manufacture of films.

The $30^{\circ}$ or $35^{\circ}$ photographic field has become the standard used in most studies of ARM. The magnification provided by a $30^{\circ}$ field is usually adequate to determine most lesions associated with ARM. Variations in field size may lead to difficulty in comparisons among studies, should be limited between $25^{\circ}$ and $40^{\circ}$, and call for adaptation of the grid template (15).

The fundus transparencies are returned as slides usually mounted in clear plastic sheets. The system of grading relies heavily on excellent quality stereoscopic transparencies, especially in detecting subtle drusen, and hyper- and hypopigmentations. This requires photographer certification and an ongoing system of quality control. Graders need an adequate time to be trained and intraand inter-individual (if there are more than one grader) variations are usually measured using a standard set of transparencies. Protocols for quality control procedures used for one study are available (9).

\section{GRADING}

Grading of ARM for epidemiological population-based studies can best be performed on stereoscopic colour slides of the macular area using standard grids. The grid templates are based on the long standing clinical convention of considering the diameter of the average optic disc to be $1500 \mu \mathrm{m}$, even though $1800 \mu \mathrm{m}$ may be a better estimate. Grading of fundus transparencies is more 


\section{Chapter 3}

reliable and provides more objective measures than ophthalmoscopy $(10,15)$. The grading system permits detailed refinement with basic standards to allow comparison of data among different studies. It also will form the basis for modifications using other examination techniques (e.g., fluorescein angiography).

To date, grading systems have used different grids, sizes of concentric grid circles, and numbers and locations of radial lines on the grids $(2,5,9)$. Common items in ARM grading have been descriptions of drusen type, size, number, confluence and area of involvement; disappearance of drusen; grading of hyperpigmentation and hypopigmentation; serous or haemorrhagic RPE detachment; RPE tears; retinal haemorrhages; hard exudates; subretinal or subRPE haemorrhage; subretinal fluid; epiretinal or subretinal fibrous or glial scar or fibrin; and geographic atrophy. Other lesions such as surface wrinkling retinopathy and peripapillary atrophy also have been graded in some systems. Other groups have also considered the fluorescein angiographic features.

When grading, the sheets of slides are placed on a fluorescent viewing box furnishing light with a Kelvin rating of approximately $6200^{\circ}$ (i.e. bluer than sunlight, which has a Kelvin rating of approximately $5400^{\circ}$ ). This wavelength was chosen because of the observation that light with a lower Kelvin rating, with its more yellow hue, was less suitable for identification of subtle drusen (Klein R, unpublished data). Graders examine the slides with stereoscopic viewers. Those used in most systems provide $5 \mathrm{x}$ magnification. Combined with approximately $3 \mathrm{x}$ magnification provided by the fundus camera, this results in a total magnification of $15 x$.

The standard grid (Figure 1) formed by opaque lines on a transparent background consists of three circles concentric with the centre of the foveola and four radial lines in an oblique position. It is superimposed over one member of the stereoscopic pair of field 2 and used to define 10 subfields. The subfields defined by the grid and their proposed names are: the central subfield (within the central circle); the middle subfield (between the central and middle circle) subdivided in superior, nasal, inferior and temporal subfields; the outer subfield (between the middle and outer circle) subdivided in superior, nasal, inferior and temporal subfields; and the mid-peripheral subfield outside the outer circle within field 2.

The circles should be reduced on a transparent sheet, according to the magnification of the fundus camera used, so that the diameter of the central circle corresponds to $1000 \mu \mathrm{m}$ in the fundus of an average eye, and the diameters of the middle and outer circle to $3000 \mu \mathrm{m}$ and $6000 \mu \mathrm{m}$, respectively. The system permits detailed grading of some lesions in each subfield or summary type grading with lesions graded either within the central, inner, or outer circles or in field 2 as a whole.

Five open circles printed on clear plastic (Figure 2) can be used to estimate size of drusen, area involved by drusen, and area involved by increased or decreased pigmentation, or by $\mathrm{AMD}$ as described below. The diameter of $\mathrm{C}_{0}$ is equivalent 


\section{Classification of age-related maculopathy}

to $63 \mu \mathrm{m}$ (more or less similar to $50 \mu \mathrm{m}$ circles used by some centres for grading), for $\mathrm{C}_{1}$ it is $125 \mu \mathrm{m}$, for $\mathrm{C}_{2}$ it is $175 \mu \mathrm{m}$, for $\mathrm{C}_{3}$ it is $250 \mu \mathrm{m}$, and for $\mathrm{C}_{4}$ it is $500 \mu \mathrm{m}$. The central circle with a diameter of $1000 \mu \mathrm{m}$ can also be used. These circles replace those used in a more detailed grading system (9).

The following grading should only be used when there are signs of ARM present. If lesions such as hard exudates, haemorrhages, hyper- or hypopigmentations are present as a result of other non age-related chorioretinal conditions (see definitions) they should be graded under "other lesions." An overview of the grading for drusen, retinal pigmentary changes, geographic atrophy and neovascular AMD is given in Tables 2 to 5.

The predominant drusen type is the most common type of drusen present within the outer circle of the grid. Large drusen $(>63 \mu \mathrm{m})$ should be counted separately but small drusen should not. The area covered by the drusen can be estimated within each of the three circles in the grid and expressed as percentage of the area within the specific subfields defined by the grid (9).

Hyperpigmentations of the retina adjacent to the optic disc and surrounding hard drusen are not graded as ARM. The term hypopigmentation of the RPE should be used instead of RPE degeneration or atrophy for depigmentations that do not meet the criteria for geographic atrophy.

Geographic atrophy is an entity different from the hyperpigmentations and hypopigmentations consisting of one or more sharply defined, roughly round or oval areas of RPE hypopigmentation with clearly visible choroidal vessels. It is graded according to presence, location and area covered by it. The minimum area involvement by geographic atrophy is that of a circle of about $175 \mu \mathrm{m}$ diameter $\left(\mathrm{C}_{2}\right)$ because it is difficult to detect choroidal vessels and determine the edges of the atrophy in smaller areas.

Neovascular AMD may be made up of non-rhegmatogenous sensory retinal detachments or serous RPE detachments. Without angiography these types of detachments may not be easily distinguishable from one another and they will both be graded as neovascular AMD. They will be graded according to presence, location, and area covered by the lesion.

If neovascular AMD has started in an eye previously classified with geographic atrophy, it is arbitrarily reclassified as neovascular AMD. If from previously demonstrated neovascular AMD, only minimal neovascular signs remain with surrounding geographic atrophy or when only geographic atrophy is visible on subsequent pictures, it still arbitrarily classified as neovascular AMD.

Definitions used in the preceding paragraphs and in the accompanying Tables provide a framework to be used in grading of colour transparencies for ARM. Extensive training with experienced graders is important prior to using this system in practice. 
Table 2. Grading of drusen.

Drusen morphology

0 . absent

1. questionable

2. small, hard drusen ( $\left.\leq \mathrm{C}_{0}, 63 \mu \mathrm{m}\right)$

3. large, soft distinct $\left(>\mathrm{C}_{0}, 63 \mu \mathrm{m}\right)$

4. large soft indistinct drusen 4a. crystalline/calcified/glistening 4b. semisolid 4c. strogranular

7. cannot grade, obscuring lesions

8. cannot grade, photo quality.

\section{Predominant drusen type}

0 . absent

1. questionable

3. small hard drusen $\left(<\mathrm{C}_{0}, 63 \mu \mathrm{m}\right)$

4. large, soft distinct ( $\geq C_{0}, 63 \mu \mathrm{m}$ )

5. large, soft indistinct $\operatorname{drusen}\left(\geq C_{1}\right.$, $125 \mu \mathrm{m}$ )

7. cannot grade, obscuring lesions

8. cannot grade, photo quality

\section{Number of drusen}

0 . absent

1. questionable

2. $1-9$

3. $10-19$

4. $\geq 20$

7. cannot grade, obscuring lesions

8. cannot grade, photo quality.

\section{Drusen size}

1. $<\mathrm{C}_{0}(<63 \mu \mathrm{m})$

2. $\geq \mathrm{C}_{0}<\mathrm{C}_{1}(\geq 63 \mu \mathrm{m},<125 \mu \mathrm{m})$

3. $\geq \mathrm{C}_{1}<\mathrm{C}_{2}(\geq 125 \mu \mathrm{m},<175 \mu \mathrm{m})$

4. $\geq \mathrm{C}_{2}<\mathrm{C}_{3}(\geq 175 \mu \mathrm{m},<250 \mu \mathrm{m})$

5. $\geq \mathrm{C}_{3}(\geq 250 \mu \mathrm{m})$

7. cannot grade, obscuring lesions

8. cannot grade, photo quality

\section{Main location of drusen.}

Drusen may not be central to indicated subfield, but may be more to periphery

1. Outside outer circle (mid-peripheral subfield)

2. In outer subfield

3. In middle subfield

4. In central subfield, 4a. outside fovea (centre point) 4b. In fovea

7. cannot grade, obscuring lesions

8. cannot grade, photo quality

Area covered by drusen in subfield 1.5
1. $<10 \%$
2. $<25 \%$
3. $<50 \%$
4. $\geq 50 \%$
7. cannot grade, obscuring lesions
8. cannot grade, photo quality. 


\author{
Hyperpigmentalion \\ 0 . absent \\ 1. questionable \\ 2. present $<\mathrm{C}_{0}(<63 \mu \mathrm{m})$ \\ 3. present $\geq \mathrm{C}_{0}(\geq 63 \mu \mathrm{m})$ \\ 7. cannot grade, obscuring lesions \\ 8. cannot grade, photo quality
}

\section{Hypopigmentation}

0 . abqent

1. questionable

2. present $<\mathrm{C}_{0}(<63 \mu \mathrm{m})$

3. present $\geq C_{0}(\geq 63 \mu \mathrm{m})$

7. cannot grade, obscuring lesions

8. cannot grade, photo quality
Main location hyper/hypopigmentation

1. Outside outer circle (mid-peripheral subfield)

2. In outer subfield

3. In middle subfield

4. In central subfield,

4a. outside fovea (centre point)

$4 b$. in fovea

7. cannot grade, obscuring lesions

8. cannot grade, photo quality

\section{Table 4. Atrophic AMD.}

\section{Presence}

0 . absent

1. questionable

2. present: $\geq \mathrm{C}_{2}$

7. cannot grade, obscuring lesions

8. cannot grade, photo quality.

\section{Location}

1. outside outer circle (mid-peripheral subsitid)

2 . in outer subfield

3 . in middle subfield

4. in central subfield

4a. not in fovea (centre point)

$4 b$, in fovea

7. cannot grade, obscuring lesions

8. cannot grade, photo quality
Area covered

1. $\geq \mathrm{C}_{2}<\mathrm{C}_{3}(\geq 175 \mu \mathrm{m}<250 \mu \mathrm{m})$

2. $\geq \mathrm{C}_{3}<\mathrm{C}_{4}(\geq 250 \mu \mathrm{m}<500 \mu \mathrm{m})$

3. $\geq \mathrm{C}_{4}$ and $<1000 \mu \mathrm{m}$

( $\sim$ central circle of grid)

4. $\geq 1000 \mu \mathrm{m}$ and $<3000 \mu \mathrm{m}$

$(\sim$ middle circle)

5. $\geq 3000 \mu \mathrm{m}$ and $<6000 \mu \mathrm{m}$

( $\sim$ outer circle)

6. $>6000 \mu \mathrm{m}$

7. cannot grade, obscuring lesions

8. cannot grade, photo quality 
Table 5. Neovascular AMD.

\author{
Presence \\ 0 . absent \\ 1. questionable \\ 2. present \\ 7. cannot grade, obscuring lesions \\ 8. cannot grade, photo quality
}

\section{Typifying features}

1. hard exudates

2. serous neuroretinal detachment

3. serous RPE detachment

4. haemorrhagic RPE detachment

5. retinal haemorrhage
5a. subretinal
$5 b$. in plane of retina
5c. subhyaloid
5d. intravitreal

6. scar/glial/fibrous tissue
6a. subretinal
6b. preretinal

7. cannot grade, obscuring lesions

8. cannot grade, photo quality

\section{Location}

1. outside outer circle (mid-peripheral subfield)

2. in outer subfield

3. in middle subfield

4. in central subfield

4a. not underlying (in.fovea)

4b. underlying (in) fovea

7. cannot grade, obscuring lesions

8. cannot grade, photo quality

Area covered

1. $\geq \mathrm{C}_{2}<\mathrm{C}_{3}(\geq 175 \mu \mathrm{m}<250 \mu \mathrm{m})$

2. $\geq \mathrm{C}_{3}<\mathrm{C}_{4}(\geq 250 \mu \mathrm{m}<500 \mu \mathrm{m})$

3. $\geq \mathrm{C}_{4}$ and $<1000 \mu \mathrm{m}$

$(\sim$ central circle of grid)

4. $\geq 1000 \mu \mathrm{m}$ and $<3000 \mu \mathrm{m}$

( $\sim$ middle circle)

5. $\geq 3000 \mu \mathrm{m}$ and $<6000 \mu \mathrm{m}$

( $\sim$ outer circle)

6. $>6000 \mu \mathrm{m}$

7. cannot grade, obscuring lesions

8. cannot grade, photo quality.

\section{SUMMARY}

There is a need for an internationally accepted nomenclature for ARM as well as for a uniform grading system for cross-sectional, longitudinal or case-control epidemiological studies. The purpose of this report is to describe a proposed grading scheme and stimulate researchers to use this system, or modifications derived from it, that will permit more comparable data collection. In addition, this classification and grading system may be useful to others using supplemental techniques of assessing AMD, such as angiography or histology. 


\section{Classification of age-related maculopathy}

\section{REFERENCES}

1. Amalric P: Historique, in Coscas G: Dégénerescence maculaire liée à l'âge. Paris, Masson, 1991, pp 7-33.

2. Bressler NM, Bressler SB, West SK, Fine SL, Taylor HR: The grading and prevalence of macular degeneration in Chesapeake Bay watermen. Arch Ophthalmol 1989;107: 847-52.

3. Diabetic Retinopathy Study Research Group: Report 7. A modification of the Airlie House Classification of diabetic retinopathy. Invest Ophthalmol Vis Sci 1981;21:210-26.

4. Goldberg J, Flowerdew G, Smith E, Brody JA, Tso MOM: Factors associated with age-related macular degeneration. Am J Epidemiol 1988;128: 700-10.

5. Gregor Z, Bird AC, Chisholm IH: Senile disciform macular degeneration in the second eye. Brit J Ophthalmol 1977;61:141-7.

6. Haab $O$. Erkrankungen der Macula lutea. Centralblatt fulr praktische Augenheilkunde 1885;9:383-4.

7. Vingerling JR, Dielemans I, Hofman A, Grobbee DE, Hijmering M, Kramer CFL, Jong PTVM de. The prevalence of age-related maculopathy in The Rotterdam Study. Ophthalmology (in press).

8. Hogan MJ, Alvarado J, Wendell JE: Histology of the Human Eye: An Atlas and Textbook. Philadelphia, Saunders, 1971, pp 344.

9. Klein R, Klein BEK, Linton KLP: Prevalence of age-related maculopathy. The Beaver Dam Ey: Study. Ophthalmology 1992;99: 933 43.

10. Klein R, Meuer SM, Moss SE, Klein BEK: Detection of drusen and early signs of age-related maculopathy using a non-mydriatic camera and a standard fundus camera. Ophthalmology 1992;99:1686-92.

11. Leibowitz H, Krueger DE, Maunder LR, et al: The Framingham Eye Study Monograph; an ophthalmological and epidemiological study of cataract, glaucoma, diabetic retinopathy, macular degeneration, and visual acuity in a general population of 2631 adults, 1973-1977. Surv Ophthalmol 1980;24 suppl: 335-610.

12. Martinez GS, Campbell AJ, Reinken J, Allan BC: Prevalence of ocular disease in a population study of subjects 65 years old and older. Am J Ophthaimol 1982;94:181-9.

13. Pagenstecher $\mathrm{H}$, Genth $\mathrm{CP}$ : Atlas der pathologischen Anatomie des Augenapfels. Wiesbaden, Kriedel CW, 1875.

14. Ryan SJ, Mittl RN, Maumenee AE: The disciform response: an historical perspective. Graefes Arch Clin Exp Ophthalmol 1980;215:1-20.

15. Sperduto RD, Hiller MR, Podgor MJ, et al: Comparability of ophthalmic diagnoses by clinical and reading center examiners in the visual acuity impairment survey pilot study. Am J Epidemiol 1986;124:994-1003.

16. Vinding T: Age-related macular degeneration. Macular changes, prevalence and sex ratio. Acta Ophthalmol 1989;67:609-16. 


\section{PREVALENCE OF AGE-RELATED MACULOPATHY IN THE ROTTERDAM STUDY}

The term age-related maculopathy (ARM) is used to label a variety of abnormalities that are observed in the macular area of elderly persons. The late stages, characterized by geographic atrophy and neovascular disease, also called age-related macular degeneration (AMD), are major causes of severe visual impairment in the elderly in industrialized countries (1). Few detailed populationbased data are available for comparison, however, especially with regard to the oldest age groups (1-4). The Rotterdam Study is the first European study that provides population-based data on ARM obtained by the grading of fundus photographs. This paper presents data on the prevalence of ARM in persons aged 55 years or over.

\section{POPULATION AND METHODS}

The Rotterdam Study is a single centre prospective follow-up study of the total population aged 55 years or over, of a suburb of Rotterdam, The Netherlands. The study has been approved by the Medical Ethics Committee of the Erasmus University, Rotterdam. Rationale and design of the study have been described elsewhere (5). In brief, the objective of the study is to investigate prevalence, incidence and determinants of chronic ophthalmological, neurological, cardiovascular and locomotor diseases. The primary ophthalmological diseases studied in the Rotterdam Study are ARM and glaucoma. Names and addresses of the residents were drawn from the municipal register. In random clusters potential participants were invited by letter, followed by a telephone call to make an appointment. All participants gave a written informed consent. Baseline data were obtained in an initial home visit with interview followed by a physical examination in the field centre. Participants living in elderly homes were examined at their home.

The ophthalmological examination was performed between March 1990 and July 1993. During this period, 10191 persons were invited to participate in the study, of which 67 had died and 350 could not be traced, resulting in 9774 eligibles. Of these 7599 persons (78\%) were visited at home and $6781(69 \%)$ participated in the ophthalmological examination in the field centre (Table 1). History data were obtained during the home visit, among others by asking the participants if they had visited an ophthalmologist in the past for other reason than for prescription of glasses. 


\section{Prevalence of age-related maculopathy}

Table 1. Age- and gender specific percentage of participation, and of ophthalmological data of study participants.

\begin{tabular}{lrrrrrrrr}
\hline & & & \multicolumn{5}{c}{ Participation percentage (number) } \\
\cline { 5 - 10 } & & Eligible & & Interview & $\begin{array}{c}\text { Ophthalmological } \\
\text { examination }\end{array}$ & $\begin{array}{c}\text { Gradable fundus } \\
\text { photographs }\end{array}$ \\
\hline Men & $55-64$ & 1418 & 82 & $(1157)$ & 78 & $(1099)$ & 73 & $(1033)$ \\
& $65-74$ & 1382 & 82 & $(1127)$ & 76 & $(1054)$ & 71 & $(977)$ \\
& $75-84$ & 796 & 72 & $(573)$ & 63 & $(505)$ & 57 & $(456)$ \\
& $85+$ & 191 & 66 & $(126)$ & 47 & $(89)$ & 38 & $(73)$ \\
& Total & 3787 & 79 & $(2983)$ & 73 & $(2747)$ & 67 & $(2539)$ \\
\hline Women & $55-64$ & 1802 & 85 & $(1540)$ & 81 & $(1466)$ & 77 & $(1391)$ \\
& $65-74$ & 1865 & 79 & $(1469)$ & 73 & $(1354)$ & 69 & $(1280)$ \\
& $75-84$ & 1505 & 71 & $(1063)$ & 59 & $(894)$ & 52 & $(788)$ \\
& $85+$ & 815 & 68 & $(544)$ & 39 & $(320)$ & 31 & $(253)$ \\
& Total & 5987 & 77 & $(4616)$ & 67 & $(4034)$ & 62 & $(3712)$ \\
\hline All & $55-64$ & 3220 & 84 & $(2697)$ & 80 & $(2565)$ & 75 & $(2424)$ \\
& $65-74$ & 3247 & 80 & $(2596)$ & 74 & $(2408)$ & 70 & $(2257)$ \\
& $75-84$ & 2301 & 71 & $(1636)$ & 61 & $(1399)$ & 54 & $(1244)$ \\
& $85+$ & 1006 & 67 & $(670)$ & 41 & $(409)$ & 32 & $(326)$ \\
& Total & 9774 & 78 & $(7599)$ & 69 & $(6781)$ & 64 & $(6251)$ \\
\hline
\end{tabular}

\section{Ophthalmological examination}

All participants were examined and had fundus photographs taken by one of three investigators. Eyes were dilated with tropicamide $0.5 \%$ and phenylephrine $5 \%$. After an average period of 45 minutes two $35^{\circ}$ colour photographs (Kodak Ektachrome 64 ASA, Topcon TRV-50VT fundus camera) centred on the macular area were taken of each eye. After photography direct and indirect ophthalmoscopy was performed. From 530 persons, fundus photographs could not be obtained due to physical inability, technical failure other reason than for prescription of glasses, or refusal. In 211 persons photographs were gradable in one eye only, and in 6040 persons, photographs of both eyes were gradable. As a result gradable fundus photographs of at least one eye were available from 6251 subjects.

\section{Photographic grading}

Photographs were graded using the definitions and grids of the Wisconsin AgeRelated Maculopathy Grading System (WARMGS) (6) by one of three graders. 


\section{Chapter 4}

All questionable lesions, and all lesions that were classified as geographic atrophy or neovascular macular degeneration were discussed and adjudicated by two of the authors. Frequent sessions of simultaneous grading were performed to maintain reproducibility. The WARMGS grid was adapted to the magnification of the camera. The slides were examined on a portable stereo viewer with fluorescent back light (Philips PL-S 9W/84; $4000^{\circ} \mathrm{K}$ ) with $5 \mathrm{x}$ magnification. Combined with a $2.5 \mathrm{x}$ magnification of the fundus camera, the total magnification was approximately $12.5 \mathrm{x}$.

\section{Definitions of age-related maculopathy}

In this study, the definitions of the WARMGS were used (6). In brief, drusen and pigmentary changes without neovascular disease or geographic atrophy were considered to be signs of early ARM. Neovascular macular degeneration and geographic atrophy were defined by WARMGS as late ARM and we called these neovascular and atrophic AMD. The grading of ARM was performed within an area $3000 \mu \mathrm{m}$ from the foveola.

Drusen were graded according to their diameter. Small drusen were defined as drusen smaller than $63 \mu \mathrm{m}$. Large drusen were defined as all drusen of $63 \mu \mathrm{m}$ or larger. Instead of estimating the area of drusen as has been done in the WARMGS, we counted the number of drusen. The exact number of small drusen was counted only in a subset of 5152 participants. The exact number of large drusen was counted separately, and the size of the predominant drusen was estimated as $63-124 \mu \mathrm{m}, 125 \mu \mathrm{m}$ or larger. The number of drusen was subclassified as either none, $1-9$, or 10 or more drusen. Retinal pigment epithelial hypopigmentation was defined as a local area of decreased pigmentation not classifiable as drusen or atrophic AMD. Increased retinal pigment was defined as any clump of increased brown, grey or black pigment of $63 \mu \mathrm{m}$ or larger. Atrophic AMD was defined as any well demarcated atrophic area of retinal pigment epithelium, with visible choroidal vessels, and without the presence of neovascular AMD. Neovascular AMD was defined as the presence of a serous or haemorrhagic retinal pigment epithelial detachment and/or a subretinal neovascular membrane and/or a subretinal haemorrhage, and/or a periretinal fibrous scar. Lesions that were considered to be the result of generalized vascular disease, such as diabetic retinopathy or chorioretinitis, or high myopia, trauma, congenital diseases or photocoagulation for other reasons than for neovascular AMD, were not included in the definition. A summary of definitions is given in Table 2.

\section{Analysis}

The data-analytic approach was as follows. We first analyzed the possible effect of non-participation in the ophthalmological study, by comparing age, gender and reason of visiting an ophthalmologist in the past. Differences in age between participants and non-participants were adjusted by direct standardization. In 


\section{Prevalence of age-related maculopathy}

participants of the ophthalmological examination, the possible effect of absent or ungradable fundus photographs on the prevalence estimate, was analyzed by comparing fundoscopically assessed ARM changes.

Table 2. Definitions

\begin{tabular}{ll}
\hline Small drusen & $\begin{array}{l}\text { Drusen }<63 \mu \mathrm{m} \text { in diameter. } \\
\text { Large drusen }\end{array}$ \\
$\begin{array}{l}\text { Retinal pigment epithelial } \\
\text { hypopigmentation }\end{array}$ & $\begin{array}{l}\text { Area of decreased pigmentation not classifiable as } \\
\text { drusen or atrophic AMD. }{ }^{\dagger}\end{array}$ \\
Increased retinal pigment & $\begin{array}{l}\text { Clumps of increased brown, grey or black } \\
\text { pigment, } \geq 63 \mu \mathrm{m} .\end{array}$ \\
Atrophic AMD & $\begin{array}{l}\text { Well demarcated area of RPE atrophy with visible } \\
\text { choroidal vessels. }\end{array}$ \\
Neovascular AMD & $\begin{array}{l}\text { Serous or haemorrhagic retinal pigment epithelial } \\
\text { detachment and/or subretinal neovascular } \\
\text { membrane and/or subretinal haemorrhage and/or } \\
\text { periretinal fibrous scar. }\end{array}$ \\
\hline
\end{tabular}

* The grading of ARM was performed within an area $3000 \mu \mathrm{m}$ from the foveola.

+ Lesions that were considered to be the result of generalized vascular disease, such as diabetic retinopathy or chorioretinitis, or high myopia, trauma, congenital diseases or photocoagulation for other reasons than for neovascular AMD, were not included in the definition.

Equality of means was tested using the $t$-test. In a substudy the reproducibility was examined. Inter- and intra observer agreement was tested with the kappa statistic. When three answers were possible, weighted kappa was used with weights of $1.0,0.75$ and 0.50 .

The prevalence data in persons were based on the eye with the most sever signs of ARM. If, for example, two eyes of a participant were discrepant with regard to the number of large drusen, the eye with the largest number of large drusen was taken. The prevalence of early ARM was computed by 10 -year age groups, and for men and women separately. Changes of the prevalence with age were tested using regression analysis and expressed in terms of 10 -year prevalence increase with $95 \%$ confidence intervals $(95 \% \mathrm{CI})$. Odds ratios, as an estimate of relative risk, were calculated by means of logistic regression as a measure of strength of the association between ARM and gender with adjustment for age. 


\section{Chapter 4}

\section{RESULTS}

Inter- and intra observer agreement was examined in a sample of 226 photographs with an oversampling for lesions (Table 3). The agreement was moderate to good (7) for most characteristics. Only the agreement of grading the number of small drusen was fair.

Participants of the Rotterdam Study were younger than those invited but not taking part (Table 4). Similarly, participants who completed the ophthalmological examination and fundus photography, were younger than those who did not. Nonparticipants were more likely to be women. In participants of the ophthalmological examination, prevalence of ophthalmoscopically observed large drusen and AMD was higher in the group with gradable photographs.

Small drusen were very common in all age groups. The prevalence of small drusen decreased with age from $83.1 \%$ in persons aged $55-64$ to $29.1 \%$ in those aged 85 years or older (regression analysis $-16.8 \%$ per 10 year; $95 \% \mathrm{Cl}-18.2$; $15.5)$. Similarly, the prevalence of $1-9$ drusen of $63-124 \mu \mathrm{m}$ decreased with age (regression analysis $-6.8 \%$ per 10 year; $95 \% \mathrm{Cl}-7.9 ;-5.7$ ) (Table 5). All other subgroups showed a significant increase with age, especially for ten or more drusen of $125 \mu \mathrm{m}$ or larger (regression analysis $2.7 \%$ per 10 year, $95 \% \mathrm{CI} 1.8$ 2.6). No sex differences were observed for the presence of drusen.

Pigmentary abnormalities were also more frequently observed with increasing age (Table 6). Regression analysis showed an increase in prevalence of $1.8 \%$ for each 10 years for retinal pigment epithelial hypopigmentation $(95 \% \mathrm{CI} 1.2-2.3)$, and $3.3 \%$ per 10 years for increased retinal pigment $(95 \% \mathrm{CI} 2.6-3.9)$. Both lesions were more frequently found in men with relative risk 1.6 for retinal pigment epithelial hypopigmentations $(95 \% \mathrm{Cl} 1.2-2.0)$ and 1.5 for increased retinal pigment respectively (95\% CI $1.2-1.9$ ).

AMD was diagnosed in 104 persons (1.7\%). The prevalence of atrophic AMD increased from $0.1 \%$ in subjects of 55.64 years to $3.7 \%$ in persons of 85 years or over (Table 7). In these age groups the prevalence of neovascular AMD was $0.1 \%$ and $7.4 \%$ respectively. No sex differences were observed for these lesions. 


\section{Prevalence of age-related maculopathy}

Table 3. Inter-and intraobserver agreement in grading of ARM related changes

\begin{tabular}{lccc}
\hline & \multirow{2}{*}{$\begin{array}{c}\text { Interobserver } \\
\text { agreement (kappa) }\end{array}$} & \multicolumn{2}{c}{$\begin{array}{c}\text { Intraobserver agreement } \\
\text { (kappa) }\end{array}$} \\
\cline { 3 - 4 } & 0.43 & 0.36 & 0.37 \\
\hline $\begin{array}{l}\text { Number of small drusen } \\
(0 ; 1-9 ; 10+)\end{array}$ & & & Reader 1 \\
$\begin{array}{l}\text { Number of large drusen } \\
(0 ; 1-9 ; 10+)\end{array}$ & 0.55 & 0.64 & 0.73 \\
$\begin{array}{l}\text { Predominant size large drusen } \\
(63-125 \mu \mathrm{m} ; \geq 125 \mu \mathrm{m})\end{array}$ & 0.46 & 0.63 & 0.64 \\
$\begin{array}{l}\text { Retinal pigment epithelial } \\
\text { hypopigmentation }\end{array}$ & 0.48 & 0.56 & 0.70 \\
Increased retinal pigment & & & 0.64 \\
AMD & 0.76 & 0.76 & 0.72 \\
\hline
\end{tabular}

Table 4. Comparison of participants and non-participants

\begin{tabular}{|c|c|c|c|c|c|}
\hline & \multirow{2}{*}{$\begin{array}{c}\text { Non- } \\
\text { participants }\end{array}$} & \multicolumn{3}{|c|}{ Study participants } & \multirow[b]{2}{*}{$\mathrm{p}$} \\
\hline & & $\begin{array}{l}\text { Interview } \\
\text { only }\end{array}$ & $\begin{array}{l}\text { Interview / } \\
\text { ophth.exam }\end{array}$ & $\begin{array}{l}\text { Interview / } \\
\text { ophth.exam./ } \\
\text { fundus phot. }\end{array}$ & \\
\hline Number & 2175 & 818 & 530 & 6251 & \\
\hline Age (years) $\dagger$ & $73.5(0.2)$ & $78.2(0.3)$ & $73.5(0.5)$ & $68.9(0.1)$ & $<0.01$ \\
\hline Gender (\% women) & 63.0 & 64.8 & 59.1 & 59.7 & 0.03 \\
\hline $\begin{array}{l}\text { Visit ophthalmologist } \\
(\%)\end{array}$ & & 40.1 & 42.5 & 41.3 & 0.71 \\
\hline \multicolumn{6}{|l|}{ Ophthalmoscopy } \\
\hline $\begin{array}{l}\text { large } \\
\text { drusen (\%) }\end{array}$ & - & - & 3.6 & 7.5 & 0.01 \\
\hline AMD (\%) & - & - & 1.3 & 2.4 & 0.09 \\
\hline
\end{tabular}

* Eligible to the study but not taking part

$\dagger$ Values are means with standard error within parentheses

$\ddagger$ History of visit to ophthalmologist in the past for other reason than prescription of glasses 


\section{Chapter 4}

Table 5. Age-specific prevalence (\%) of large drusen within $3000 \mu \mathrm{m}$ from the fovea of the worst eye, subclassified for size and number.

\begin{tabular}{|c|c|c|c|c|c|c|}
\hline \multirow{3}{*}{ Age } & \multicolumn{6}{|c|}{ Size and number of predominant large drusen } \\
\hline & \multicolumn{2}{|c|}{$63 \mu \mathrm{m}-124 \mu \mathrm{m}$} & \multicolumn{2}{|c|}{$125 \mu \mathrm{m}$ or larger } & \multicolumn{2}{|c|}{ Total } \\
\hline & $1-9$ & $10+$ & $1-9$ & $10+$ & $1-9$ & $10+$ \\
\hline $55-64$ & 33.0 & 2.7 & 4.6 & 0.5 & 37.6 & 3.2 \\
\hline $65-74$ & 37.2 & 6.0 & 6.9 & 1.4 & 44.1 & 7.3 \\
\hline $75-84$ & 31.5 & 9.5 & 10.1 & 4.8 & 41.6 & 14.4 \\
\hline $85+$ & 25.6 & 8.8 & 11.4 & 6.8 & 37.0 & 15.6 \\
\hline Total & 33.9 & 5.5 & 6.8 & 2,0 & 40.7 & 7.5 \\
\hline
\end{tabular}

Table 6. Age-specific prevalence (\%) of pigmentary abnormalities in the worst eye.

\begin{tabular}{|c|c|c|c|c|c|c|c|c|c|}
\hline \multirow[t]{2}{*}{ Age (yr) } & \multicolumn{3}{|c|}{$\begin{array}{l}\text { Retinal pigment } \\
\text { epithelial } \\
\text { hypopigmentation }\end{array}$} & \multicolumn{3}{|c|}{$\begin{array}{l}\text { Increased retinal } \\
\text { pigment }\end{array}$} & \multicolumn{3}{|c|}{$\begin{array}{c}\text { Total pigmentary } \\
\text { abnormalities }\end{array}$} \\
\hline & Men & Women & All & Men & Women & All & Men & Women & All \\
\hline $55-64$ & 4.5 & 2.7 & 3.5 & 4.1 & 3.4 & 3.7 & 5.7 & 4.0 & 4.8 \\
\hline $65-74$ & 4.8 & 3.3 & 4.0 & 7.2 & 3.7 & 5.2 & 9.0 & 4.7 & 6.5 \\
\hline $75-84$ & 8.1 & 5.0 & 6.1 & 10.3 & 8.7 & 9.3 & 12.5 & 9.8 & 10.8 \\
\hline $85+$ & 10.3 & 8.6 & 9.0 & 20.6 & 13.8 & 15.3 & 23.5 & 15.5 & 17.3 \\
\hline Total & 5.4 & 3.8 & 4.4 & 6.8 & 5.2 & 5.9 & 8.7 & 6.2 & 7.2 \\
\hline
\end{tabular}

Table 7. Age- and gender specific prevalence (\%) of atrophic AMD and neovascular AMD in participants of the Rotterdam Study.

\begin{tabular}{|c|c|c|c|c|c|c|c|c|c|}
\hline \multirow{2}{*}{ Age (yr) } & \multicolumn{3}{|c|}{ Atrophic AMD } & \multicolumn{3}{|c|}{ Neovascular AMD } & \multicolumn{3}{|c|}{ Total AMD } \\
\hline & Men & Women & All & Men & Women & All & Men & Women & All \\
\hline $55-64$ & 0.2 & 0.0 & 0.1 & 0.1 & 0.1 & 0.1 & 0.3 & 0.1 & 0.2 \\
\hline $65-74$ & 0.6 & 0.2 & 0.4 & 0.3 & 0.5 & 0.4 & 0.9 & 0.6 & 0.8 \\
\hline $75-84$ & 1.1 & 1.4 & 1.3 & 2.4 & 2.4 & 2.4 & 3.5 & 3.8 & 3.7 \\
\hline $85+$ & 2.7 & 4.0 & 3.7 & 6.8 & 7.5 & 7.4 & 9.6 & 11.5 & 11.0 \\
\hline Total & 0.6 & 0.6 & 0.6 & 0.8 & 1.2 & 1.1 & 1.4 & 1.9 & 1.7 \\
\hline
\end{tabular}




\section{Prevalence of age-related maculopathy}

\section{DISCUSSION}

In this study we examined the prevalence of ARM in an elderly population in the Netherlands. The findings can be used for comparison with other populations but only after some methodological issues have been mentioned. The effect of nonresponse on our findings has to be considered because it is likely that nonresponse is related to disease. Persons without gradable fundus photographs had a lower prevalence of large drusen and AMD, according to the fundoscopic examination, which could have led to an overestimation of the prevalence of ARM. This could, however, also be due to increased media opacities in this group. The frequency of visiting an ophthalmologist for other reason than for glasses was not different in participants with and without ophthalmological examination, suggesting that a selection with regard to disease did not occur. In the oldest age-category, the percentage of people in whom gradable fundus photographs could be obtained was small. Therefore the estimates in this group need to be interpreted with caution. In this study the photographs were monoscopic which could have resulted in an underestimation of the prevalence of AMD, by missing subtle pigment epithelial detachments. In addition, the availability and quality of photographs declined with age due to the increasing prevalence of media opacities and physical impairment of the participants. As a result, subtle macular changes become less visible with increasing age. The inverse relation between small drusen and age could have resulted from this problem. Likewise, other changes like small clumps of retinal pigment and small areas of atrophy could have been underestimated in the older age-groups.

Comparison with other population-based studies, notably of AMD, is best possible with the Chesapeake Bay Study and the Beaver Dam Eye Study $(2,4)$. Both studies used similar methods of case-ascertainment and assessment of the prevalence of ARM. Other studies used different methods which makes comparison more difficult $(1,3)$. We made no attempt to define early ARM as a bounded entity because the criteria for such a definition are still very arbitrary. For comparison, the separate abnormalities are used. With respect to the early stages of ARM, the prevalence of any drusen of $63 \mu \mathrm{m}$ or larger is higher in the present study than in Chesapeake Bay and Beaver Dam. Small differences in grading and photographic techniques, particularly camera magnification and adaptation of the grid, could have caused the discrepancy, although a real difference may also be present. Assuming that the methodology is responsible for the difference, any drusen of $125 \mu \mathrm{m}$ or larger would be a more appropriate, although still arbitrary, cutoff point for large drusen in this study. The prevalence of increased retinal pigment in men was similar to that in Chesapeake Bay but approximately three times lower than in Beaver Dam. The reason for this is not clear. Our observation that increased retinal pigment is more common in men was observed in Beaver Dam only in subjects below 65 years. In people older than 75 years of age, the Beaver Dam Eye Study reported a higher risk for women to 


\section{Chapter 4}

have pigmentary changes.

In Figure 1, a comparison is made between the age-specific prevalence of AMD in the Rotterdam Study, and two population-based studies conducted in the USA $(2,4)$ The estimates from Framingham are not included since they concerned neovascular AMD only. The present study shows the lowest estimates. It is conceivable that a part of the difference may have resulted from the use of non stereoscopic photographs in the present study. A real difference must be also be considered however. The excess risk of neovascular AMD in women aged 75-84 years that was reported in the Beaver Dam Eye Study (4) and the Framingham Eye Study (1), was not observed in the present study.

In conclusion, the results of this study suggest that age-related maculopathy may be less common in this European population than in similar populations in the USA.

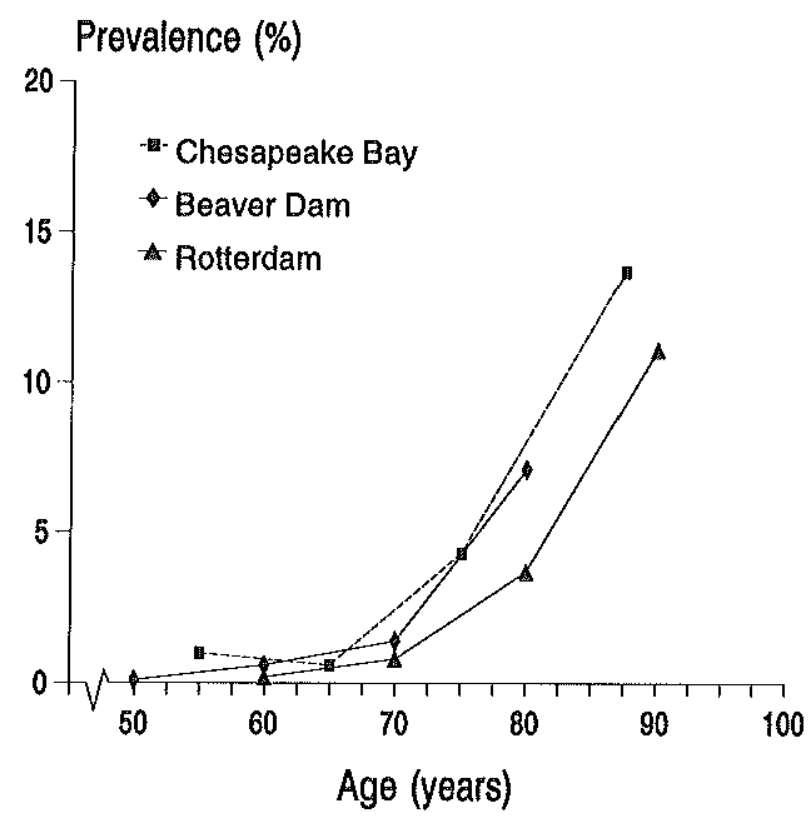

Figure 1. Comparison of the prevalence of age-related macular degeneration (atrophic or neovascular) in population-based studies. 


\section{Prevalence of age-related maculopathy}

\section{REFERENCES}

1. Leibowitz H, Krueger DE, Maunder LR, Milton RC, Kini MM, Kahn HA, Nickerson RJ, Pool J, Colton TL, Ganley JP, Loewenstein JI, Dawber TR. The Framingham Eye Study Monograph: an ophthalmological and epidemiological study of cataract, glaucoma, diabetic retinopathy, macular degeneration, and visual acuity in a general population of 2631 adults, 19731977. Surv Ophthalmol 1980;24:335-610.

2. Bressler NM, Bressler SB, West SK, Fine SL, Taylor HR. The grading and prevalence of macular degeneration in Chesapeake Bay watermen. Arch Ophthalmol 1989;107:847-52.

3. Vinding T. Age-related macular degeneration. Macular changes, prevalence and sex ratio. An epidemiological study of 1000 aged individuals. Acta Ophthalmol 1989;67:609-16.

4. Klein R, Klein BEK, Linton KLP. Prevalence of age-related maculopathy. The Beaver Dam Eye Study. Ophthalmol 1992;99:933-43.

5. Hofman A, Grobbee DE, Jong PTVM de, Ouweland FA van den. Determinants of dise se and disability in the elderly: the Rotterdam Elderly Study. Eur J Epidemiol 1991;7:403-22.

6. Klein R, Davis MD, Magli YL, Klein BEK. The Wisconsin Age-Related Maculopathy Grading System. Ophthalmology 1991;98:1128-34.

7. Altman DG. Practical statistics for medical research, 1st ed. London: Chapman \& Hall, 1993:404-5. 


\section{ATHEROSCLEROSIS IS ASSOCIATED WITH AGE-RELATED MACULAR DEGENERATION}

Age-related macular degeneration is the most frequent cause of severe irreversible visual impairment in the elderly in industrialized countries (1-4). It affects the macula lutea of the retina resulting in a central scotoma in the visual field in the late stages. The etiology of the disease is poorly understood. A vascular basis of macular degeneration was first suggested by Verhoeff and coworkers (5) and subsequently by others $(6,7)$. This hypothesis, however, was never confirmed. With the availability of recent non-invasive techniques to assess vessel wall characteristics, it is possible to explore whether atherosclerosis plays a role in the pathogenesis of macular degeneration in populations at large. In the present study we evaluated the association between non-invasively assessed carotid atherosclerosis, lower extremity arterial disease and macular degeneration in the population-based Rotterdam Study.

\section{MATERIALS AND METHODS}

The Rotterdam Study is a single centre prospective follow-up study of the total population aged 55 years and over, of a city district in Rotterdam, The Netherlands. The study has been approved by the Medical Ethics Committee of the Erasmus University, Rotterdam. Rationale and design of the study have been described elsewhere (8). In brief, the objective of the study is to investigate prevalence, incidence and determinants of chronic ophthalmological, neurological, cardiovascular and locomotor diseases. Ophthalmological diseases studied in the Rotterdam Study are age-related maculopathy and glaucoma. Of the eligible 10275 subjects, $7983(78 \%)$ participated in the study. All participants gave a written informed consent. Baseline data were obtained in an initial home visit with interview followed by a physical examination in the field centre. Participants living in homes for the elderly were examined at their home. The present study included data of all study participants with macular degeneration (104 cases) and the first 1324 participants without macular degeneration of whom ultrasonography data were evaluated.

Eyes were dilated with tropicamide $0.5 \%$ and phenylephrine $5 \%$. After, on average, 45 minutes two $35^{\circ}$ colour transparencies (Kodak Ektachrome 64 ASA, Topcon TRV-50VT fundus camera) centred on the macular area were taken of each eye. Photographs were graded using the definitions and grids of the Wisconsin Age-Related Maculopathy Grading System (9) by three trained graders. The graders were blinded for the results of other measurements. Gradable fundus photographs of at least one eye could be obtained in 6251 participants (82\%). 
Macular degeneration was diagnosed if either geographic atrophy or neovascular macular degeneration was present in at least one eye. Geographic atrophy was defined as any well demarcated area of retinal pigment epithelium (RPE) atrophy with visible choroidal vessels without the presence of neovascular macular degeneration. Neovascular macular degeneration, was defined as the presence of serous or haemorrhagic retinal pigment epithelial detachments, periretinal haemorrhages, subretinal neovascular membranes or subretinal fibrous scars in the absence of generalized retinal vasculopathy. The reproducibility of the grading of macular degeneration was good (10).

Ultrasonography of both carotid arteries was performed using a $7.5-\mathrm{MHz}$ linear-array transducer and a duplex scanner (ATL UltraMark IV, Advanced Technology Laboratories, Bethel, Washington, USA) (11). According to the Rotterdam Study ultrasound protocol, a careful search was performed for the lumen-intima interface and media-adventitia interface of the far wall of the distal common carotid artery $(12,13)$. When an optimal image was obtained, it was 'frozen' on the $\mathrm{R}$ wave of the electrocardiogram and stored on videotape. This procedure was repeated three times for both sides. Subsequently the common carotid artery and carotid bifurcation were evaluated on-line for the presence of atherosclerotic lesions, defined as focal widening relative to adjacent segments, with protrusion into the lumen. The entire ultrasound procedure was stored on videotape. Measurement of the intima-media thickness was performed off-line, as described in detail previously $(14,15)$. The presence of atherosclerotic plaques in the common carotid artery and in the carotid bifurcation was assessed from stored images on videotape. The validity and reproducibility of carotid atherosclerosis measurements have been described by Wong and co-workers and Bots and coworkers respectively, indicating good validity and reproducibility $(16,17)$. Atherosclerosis in the arteries of the lower extremities was studied by the ratio of the systolic blood pressure at the ankle to the systolic blood pressure at the arm (11). The systolic blood pressure level of the posterior tibial artery was measured at both sides using an 8-MHz continuous wave doppler probe (Huntleigh $500 \mathrm{D}$, Huntleigh Technology, Bedfordshire, UK) and a random-zero sphygmomanometer. For each leg the ankle-arm index was calculated, the lowest index was used in the analysis $(11,18,19)$. In conformity with criteria proposed by Fowkes and coworkers (19), and by Schroll and Munck (20), an ankle-arm index less than 0.90 on at least one side was used to select a group with a high probability of having lower extremity arterial disease. The ankle-arm index reflects atherosclerosis of the arteries of the lower extremities and is a strong predictor of future atherosclerotic cardiovascular disease $(21,22)$.

During two visits at the research centre several cardiovascular risk factors were measured. Sitting blood pressure was measured at the right upper arm using a random-zero sphygmomanometer. The average of two measurements obtained at one occasion, separated by a count of pulse rate, was used in the analysis. Hypertension was defined as a systolic blood pressure level of $160 \mathrm{mmHg}$ or over 


\section{Chapter 5}

and/or a diastolic blood pressure level of $95 \mathrm{mmHg}$ or over and/or current use of antihypertensive drugs for the indication of hypertension.

A venipuncture was performed, applying minimal stasis, using a 21 gauge Butterfly needle with tube (Surflo winged infusion set, Terumo, Belgium). Serum total cholesterol was determined by means of an automated enzymatic procedure (23). High density lipoprotein (HDL) cholesterol was measured similarly, after precipitation of the non HDL fraction with phosphotungstate-magnesium.

The prevalences of characteristics in subjects with and without macular degeneration and differences between these groups were calculated with adjustment for age and gender using logistic regression analysis. Continuous variables were adjusted for age and gender using analysis of covariance. Age was entered in the model as a continuous variable. The prevalence odds ratio of macular degeneration according to presence or absence of atherosclerosis was estimated by logistic regression analysis with adjustment for age and gender, and corresponding 95 percent confidence intervals $(95 \% \mathrm{CI})$ were calculated. To assess whether the magnitude of the associations was modified by age, the analyses were initially performed in four 10-year age strata with adjustment for confounding by age within these strata. Age strata within which the directions of the associations were similar, were grouped into one age category to obtain sufficient numbers of cases. This strategy resulted in two age strata of 55-84 years and 85 years and over, respectively.

\section{RESULTS}

Macular cegeneration was diagnosed in 104 participants of the Rotterdam Study (1.7\% 95\% CI 1.3-2.0). The prevalence of macular degeneration was $1.1 \%$ (68 cases) in those below 85 years $(95 \% \mathrm{Cl} 0.9-1.4)$, and $11.0 \%$ (36 cases) in subjects aged 85 years and over (95\% CI 7.6-14.4). Age and gender specific data on the prevalence of nacular degeneration in the Rotterdam Study are shown in table 1 (10). Data on atherosclerosis were available from 96 subjects with macular degeneration. General characteristics of the study population and in subjects with and without macular degeneration are shown in table 2. Subjects with macular degeneration were older and more likely to be current smokers. Diastolic blood pressure was marginally higher in cases with macular degeneration, other cardiovascular risk factors were not significantly different.

In table 3 age- and gender-adjusted indicators of atherosclerosis according to presence ur absence of macular degeneration are given. Plaques in the carotid bifurcation and common carotid artery were more frequently observed in subjects with macular degeneration than in controls. No differences were observed in intima-media thickness of the common carotid artery in the total group or within the two age-categories. Subjects with macular degeneration had a lower mean ankle-arm index and presented more frequently with lower extremity arterial 
disease than controls.

Table 4 shows the associations between indicators of atherosclerosis and macular degeneration. Plaques in the carotid bifurcation were associated with a 4.5 times increased prevalence odds of macular degeneration (95\% CI 1.9-10.7). Subjects with plaques in the common carotid artery and those with lower extremity arterial disease had a 2.0 times increased prevalence odds of

Table 1. Age and gender specific prevalence (number) of atrophic and neovascular $A M D$ in the Rotterdam Study.

\begin{tabular}{llrrrrrrr}
\hline & \multirow{2}{*}{ Age (yr) } & \multicolumn{2}{c}{ Atrophic } & \multicolumn{3}{c}{ Neovascular } & \multicolumn{2}{c}{ All } \\
\hline \multirow{2}{*}{ Men } & $55-84$ & 0.5 & $(13)$ & 0.6 & $(15)$ & 1.1 & $(28)$ \\
& $85+$ & 2.7 & $(2)$ & 6.8 & $(5)$ & 9.6 & $(7)$ \\
\multirow{4}{*}{ Women } & $55-84$ & 0.4 & $(13)$ & 0.8 & $(27)$ & 1.2 & $(40)$ \\
& $85+$ & 4.0 & $(10)$ & 7.5 & $(19)$ & 11.5 & $(29)$ \\
\multirow{4}{*}{ All } & $55-84$ & 0.4 & $(26)$ & 0.7 & $(42)$ & 1.1 & $(68)$ \\
& $85+$ & 3.6 & $(12)$ & 7.4 & $(24)$ & 11.0 & $(36)$ \\
\hline
\end{tabular}




\section{Chapter 5}

Table 2. General characteristics of the study population *

\begin{tabular}{|c|c|c|c|c|}
\hline & \multicolumn{3}{|c|}{ Macular degeneration } \\
\hline & & $\begin{array}{l}\text { Present } \\
(\mathrm{N}=96)\end{array}$ & Absent $(\mathrm{N}=1324)$ & $\mathrm{P}^{\dagger}$ \\
\hline \multicolumn{2}{|l|}{ Age (years) } & $81.2(0.8)$ & $70.3(0.2)$ & $<0.01$ \\
\hline \multicolumn{2}{|l|}{ Gender (women \%) } & 62 & 63 & 0.88 \\
\hline \multicolumn{2}{|c|}{ Body mass index $\left(\mathrm{kg} / \mathrm{m}^{2}\right)$} & $26.5(0.4)$ & $26.7(0.1)$ & 0.61 \\
\hline \multirow[t]{3}{*}{ Cigarette smoking } & current $(\%)$ & 30 & 20 & 0.01 \\
\hline & former $(\%)$ & 39 & 40 & 0.83 \\
\hline & never $(\%)$ & 31 & 40 & 0.04 \\
\hline \multicolumn{2}{|c|}{ Systolic blood pressure $(\mathrm{mmHg})$} & $135.8(2.2)$ & $137.9(0.5)$ & 0.32 \\
\hline \multicolumn{2}{|c|}{ Diastolic blood pressure $(\mathrm{mmHg})$} & $73.5(1.2)$ & $71.1(0.3)$ & 0.07 \\
\hline \multicolumn{2}{|l|}{ Hypertension ${ }^{\ddagger}(\%)$} & 30 & 33 & 0.47 \\
\hline \multicolumn{2}{|c|}{ Total cholesterol $(\mathrm{mmol} / \mathrm{l})$} & $6.5(0.1)$ & $6.6(0.3)$ & 0.29 \\
\hline \multicolumn{2}{|c|}{ HDL cholesterol $(\mathrm{mmol} / \mathrm{l})$} & $1.4(0.04)$ & $1.3(0.01)$ & 0.16 \\
\hline
\end{tabular}

* Values are means with standard deviation in parentheses or percentages, adjusted for age and, when appropriate, for gender.

$\dagger \quad P$ value for the difference between subjects with and without macular degeneration, adjusted for age and gender.

\$ Systolic blood pressure $>160 \mathrm{mmHg}$ and/or diastolic blood pressure $>95 \mathrm{mmHg}$ and/or current use of antihypertensive drugs for the indication of hypertension. 
Table 3. Indicators of atherosclerosis in subjects with and without macular degeneration."

\begin{tabular}{lccc}
\hline & \multicolumn{3}{c}{ Macular degeneration } \\
\cline { 2 - 4 } & Present & Absent & $\mathrm{P}^{\dagger}$ \\
\hline Carotid arteries & 87 & 59 & 0.0004 \\
Plaques in carotid bifurcation (\%) & 30 & 18 & 0.005 \\
Plaques in common carotid artery (\%) & $1.01(3.3)$ & $1.03(0.8)$ & 0.62 \\
Carotid intima-media thickness (mm) & & & \\
Lower extremities & $0.99(0.02)$ & $1.07(0.01)$ & 0.01 \\
Ankle-arm index & 26 & 15 & 0.006 \\
Lower extremity arterial disease (\%) &
\end{tabular}

- Values are means with standard errors in parentheses or percentages, adjusted for age and gender.

$\dagger \quad$ P value for the difference between groups, adjusted for age and gender.

Table 4. Prevalence odds ratio of macular degeneration according to indicators of atherosclerosis in two age groups."

Prevalence odds ratio $(95 \% \mathrm{CI})$ of the presence

of macular degeneration

\begin{tabular}{ccc}
\hline $55-84$ years & $\begin{array}{c}85 \text { years and } \\
\text { over }\end{array}$ & Total \\
\hline
\end{tabular}

\begin{tabular}{llll}
\hline Plaques in carotid arteries & & & \\
Carotid bifurcation & $4.7(1.8-12.2)$ & $3.5(0.4-32.9)$ & $4.5(1.9-10.7)$ \\
Common carotid artery & $2.5(1.4-4.5)$ & $0.9(0.4-2.3)$ & $2.0(1.2-3.2)$ \\
$\begin{array}{l}\text { Lower extremity arterial } \\
\text { disease }^{\dagger}\end{array}$ & $2.5(1.4-4.5)$ & $1.1(0.5-2.6)$ & $2.0(1.2-3.2)$ \\
\hline
\end{tabular}

* Adjusted for age and gender.

$\dagger$ Ankle-arm index less than 0.90 on at least one side. 
macular degeneration (95\% CI 1.2-3.2). The associations were notably present in subjects younger than 85 years. In persons aged 85 years and over, only those with plaques in the carotid bifurcation appeared to have an increased risk, but this was not statistically significant.

All observed associations were similar in men and women, and for atrophic and neovascular macular degeneration. Additional analyses with adjustment for the possible confounding effect of smoking, hypertension and cholesterol, did not change the magnitude of the associations.

\section{DISCUSSION}

These findings suggest that macular degeneration may be associated with atherosclerosis in an older population. This association appears particularly pronounced in subjects between 55 and 85 years of age. Before we accept these findings some methodological issues have to be discussed. First, caution is needed regarding a causal interpretation of the results. The data were obtained in a crosssectional study and indicators of atherosclerosis and macular degeneration were measured simultaneously. Yet, it seems highly unlikely that macular degeneration leads to atherosclerosis rather than the reverse. Second, non-participation may have affected our findings. The response rate in the Rotterdam Study is relatively high; still, non-responders to the study are likely to have more disease, which could have resulted in an underestimation of the prevalence of both macular degeneration and atherosclerosis. We consider it unlikely, however, that the association between the two is due to non-response.

Previous studies have reported contradictory results on the association between a history of cardiovascular disease and macular degeneration as an approximation of atherosclerosis, some showing positive associations (24-26) and others not (27. 30 ). In one study hypertension as determined 25 years before eye examination was associated with macular degeneration (31). Other studies used blood pressure levels taken at the time of eye examination and observed a positive association with increased systolic blood pressure $(30,32)$, though not uniformly (29). Increased total serum-cholesterol was associated with an increased risk of neovascular macular degeneration in a one study (30), but could not be confirmed in another (29). The assessment of atherosclerosis directly with non-invasive techniques in our study may have resulted in more specific data.

It is conceivable that atherosclerosis plays a direct role in the development of macular degeneration by affecting the flow and permeability of choroidal vessels. A prolonged filling of the choroidal capillaries has been described in patients with macular degeneration (33). This phenomenon can be explained by thickening of Bruch's membrane, but also by a decreased perfusion of the choroidal capillaries (33). In histological studies of macular degeneration, choroidal capillaries show a decreased density (34) and thickening of the intercapillary pillars (34-36), but 


\section{Atherosclerosis and AMD}

the etiology of these changes is unclear. There is evidence that the choroidal capillaries are regulated by the retinal pigment epithelium $(37,38)$. Decreased functioning of the retinal pigment epithelium, which is seen in macular degeneration, could therefore cause atrophy of the choroidal capillaries. Light exposure was suggested to be a factor in the pathogenesis of macular degeneration $(40,41)$ since it has a damaging effect on photoreceptors and retinal pigment epithelium $(42,43)$. In epidemiologic studies, however, the relation between light exposure and macular degeneration is weak $(24,30,44,45)$.

Alternatively, there may also be a systemic basis for the capillary alterations which in turn causes damage to the retinal pigment epithelium (34). Possibly, these capillary changes are caused by atherosclerosis. The exact mechanism remains to be clarified, however.

The association could have occurred indirectly through a risk factor involved in the pathogenesis of both atherosclerosis and macular degeneration. However, adjustments for such possibly shared risk factors, such as smoking, hypertension and cholesterol, did not alter the magnitude of the association. A deficiency of anti-oxidants could be an interesting candidate as a shared risk factor since this has been reported to be involved in both atherosclerosis (39) and macular degeneration (30).

Indicators of atherosclerosis measured in the Rotterdam Study were associated with macular degeneration only below age 85 years. One explanation for the modifying effect of age could be a higher mortality among subjects with macular degeneration and atherosclerosis as compared to those with atherosclerosis alone. We did not find an increased intima-media thickness of the common carotid artery in cases with macular degeneration. Carotid plaques are an indicator of more advanced atherosclerotic process compared to common carotid intima-media thickness, which represents an earlier sign of atherosclerosis. The association with macular degeneration may therefore differ.

In conclusion, these results suggest that atherosclerosis may be implicated in the etiology of macular degeneration. Further studies must reveal whether the association is based on a direct causal effect or on shared risk factors. 


\section{Chapter 5}

\section{REFERENCES}

1. Kahn HA, Moorhead HB: Statistics on blindness in the Model Reporting Areas 1969-1970. United States Department of Health, Education and Welfare Publication No. (NIH) 73-427. Washington, DC, US Government Printing Office, 1973.

2. Leibowitz H, Krueger DE, Maunder LR, et al. The Framingham Eye Study Monograph. Surv Ophthalmol 1980;24:335-610.

3. National Advisory Eye Council. Report of the Retinal and Choroidal Disease Panel: Vision Research: A National Plan: 1983-1987. Washington, DC: US Dept of Health and Human Services; 1984. NIH publication 83-2471.

4. Ghafour IM, Allan D, Foulds WS. Common causes of blindness and visual handicap in the west of Scotland. Br J Ophthalmol 1983; 67:209-13.

5. Verhoeff FH, Grossman HP. Pathogenesis of disciform degeneration of the macula. Arch Ophthalmol 1937;18:561-85.

6. Gass JDM. Pathogenesis of disciform detachment of the neuroepithelium III Senile disciform macular degeneration. Am J Ophthalmol 1967;63:573-711.

7. Kornzweig AL. Changes in the choriocapillaris associated with senile macular degeneration. Ann Ophthalmol 1977;9:753-64.

8. Hofman A, Grobbee DE, de Jong PTVM, et al. Determinants of disease and disability in the elderly: the Rotterdam Elderly Study. Eur J Epidemiol 1991;7:403-22.

9. Klein R, Davis MD, Magli YL, et al. The Wisconsin Age-related Maculopathy Grading System. Ophthalmology 1991;98:1128-34.

10. Vingerling JR, Dielemans I, Hofman $A$, et al. Prevalence of age-related maculopathy in the Rotterdam Study. Ophthalmology 1995;102:205-10.

11. Bots ML, Swieten JC van, Breteler MMB, et al. Cerebral white matter lesions and atherosclerosis in the Rotterdam Study. Lancet 1993;341:1232-7.

12. Bots ML, Meurs JCHM van, Grobbee DE. Assessment of early atherosclerosis: A new perspective. J Drug Res 1991;16:150-4.

13. Wikstrand J, Wiklund $O$. Frontiers in cardiovascular science. Quantitative measurements of atherosclerotic manifestations in humans. Arterioscler Thromb 1992;12:114-9.

14. Wendelhag I, Gustavsson T, Suurkula M, et al. Ultrasound measurement of wall thickness in the carotid artery: Fundamental principles, and description of computerized analyzing system. Clin Physiol 1991;11:565-77.

15. Bots ML, Hofman A, de Bruyn AM, et al. Isolated systolic hypertension and vessel wall thickness of the carotid artery. The Rotterdam Elderly Study. Arterioscler Thromb 1993;13:64-9.

16. Wong $M$, Edelstein J, Wollman J, Bond MG. Ultrasonic-pathological comparison of the human arterial wall. Verification of intima-media thickness. Arterioscl Thromb 1993;13:482-6.

17. Bots ML, Mulder PGH, Hofman A, van Es GA, Grobbee DE. 
Reproducibility of carotid vessel wall thickness measurements. The Rotterdam Study. J Clin Epidemiol 1994;47:921-30.

18. Vogt MT, Wolfson SK, Kuller LH. Lower extremity arterial disease and the ageing process: A review. J Clin Epidemiol 1992;45:529-42.

19. Fowkes FGR, Houseley E, Cawood EHH, et al. Edinburgh artery study: Prevalence of asymptomatic and symptomatic peripheral arterial disease in the general population. Int J Epidemiol 1991;20:384-92.

20. Schroll M, Munck $O$. Estimation of periferal arteriosclerotic disease by ankle blood pressure measurements in a population of 60 year old men and women. J Chronic Dis 1981;34:261-9.

21. Fowkes. The measurement of atherosclerotic peripheral disease in epidemiological studies. Int J Epidemiol 1988;17:248-54.

22. Vogt MT, Wofson SK, Kuller LH. Lower extremity arterial disease and the ageing process: A review. J Clin Epidemiol 1992;45:529-42.

23. Vangent CM, Vandervoort HA, De Bruyn AM, et al. Cholesterol determinations. A comparative study of methods with special reference to enzymatic procedures. Clin Chem Acta 1977;75:243-251.

24. Hyman LG, Lilienfeld AM, Ferris FL, et al. Senile macular degeneration: a case control study. Am J Epidemiol 1983;118:213-27.

25. Delaney WV, Oates RP. Senile macular degeneration: a preliminary study. Ann Ophthalmol 1982;14:21-4.

26. Vidaurri JS, Pe'er J, Halfon ST, et al. Association between drusen and some risk factors for coronary artery disease. Ophthalmologica 1984;188:243-7.

27. Maltzman BA, Mulvihill MN, Greenbaum A. Senile macular degeneration and risk factors: a case-control study. Ann Ophthalmol 1979;11:1197-201.

28. Blumenkranz MS, Russell SR, Robey MG, et al. Risk factors in age-related maculopathy complicated by choroidal neovascularization. Ophthalmology 1986;93:552-8.

29. Klein R, Klein BEK, Franke T. The relationship of cardiovascular disease and its risk factors to age-related maculopathy. The Beaver Dam Eye Study. Ophthalmology 1993;100:406-14.

30. The Eye Disease Case-Control Study Group: Risk factors for neovascular age-related macular degeneration. Arch Ophthalmol 1992;110:1701-8.

31. Sperduto RD, Hiller R: Systemic hypertension and age-related maculopathy in the Framingham Study. Arch Ophthalmol 1986;104:216-9.

32. Klein BEK, Klein R. Cataracts and macular degeneration in older americans. Arch Ophthalmol 1982;100:571-3.

33. Pauleikhoff $\mathrm{D}$, Chen JC, Chisholm IH, et al. Choroidal perfusion abnormality with age-related Bruch's membrane change. Am J Ophthalmol 1990;109:211-7.

34. Ramrattan RS, van der Schaft TL, Mooy CM, et al. Morphometric analysis of Bruch's membrane, the choriocapillaris, and the choroid in aging. Invest Ophthalmol Vis Sci 1994;35:2857-64. 
35. Friedman E, Smith TR, Pathogenesis: senile changes of the choriocapillaris of the posterior pole. Trans Am Acad Ophthalmol Oto-Laryngol $1965 ; 69: 652-61$.

36. van der Schaft TL, Mooy CM, de Bruijn WC, et al. Histological features of the early stages of age-related macular degeneration. A statistical analysis. Ophthalmology 1992;99:278-86.

37. Korte GE, Repucci V, Henkind P. RPE destruction causes choriocapillary atrophy. Invest Ophthalmol Vis Sci 1984;25:1135-45.

38. Glaser BM, Campochiaro PA, Davis JL, et al. Retinal pigment epithelial cells release an inhibitor of neovascularization. Arch Ophthalmol 1985;103:1870-5.

39. Steinberg D. Antioxidants and atherosclerosis. A current assessment. Circulation $1991 ; 84: 1420-5$.

40. Tso MOM, Woodford BJ. Effects of photic injury on the retinal tissues. Ophthalmology 1983;90:953-63.

41. Mainster MA, Ham WT, Delori FC. Potential retinal hazards. Instrument and environmental light sources. Ophthalmology 1983;90:927-32.

42. Ham WT, Muller HA. The photopathology and nature of the blue light and near-UV retinal lesions produced by lasers and other optical sources. Laserapplications in medicine and biology (1989). Ed. Wolbarhst. Plenum, New York.

43. Noell WK. Possible mechanisms of photoreceptor damage by light in mammalian eyes. Vis Res 1980;20:1163-71.

44. West SK, Rosenthal FS, Bressler NM, Bressler SB, Munoz B, Fine SL, Taylor HR. Exposure to sunlight and other risk factors for age-related macular degeneration. Arch Ophthalmol 1989;107:875-9.

45. Cruickshanks KJ, Klein R, Klein BEK. Sunlight and age-related macular degeneration. The Beaver Dam Eye Study. Arch Ophthalmol 1993;11 1:514-8. 


\title{
CHAPTER 6 \\ SMOKING AND AGE-RELATED MACULAR DEGENERATION
}

\begin{abstract}
Age-related macular degeneration is the most common cause of severe irreversible visual impairment in elderly people (1). It affects the macula lutea of the retina resulting in a central scotoma in the visual field. The etiology of the disease is poorly understood. An increased risk of macular degeneration in smokers was first suggested by Hyman et al. (2) and confirmed in some other studies (3-5), although not uniformly $(6,7)$. It has been proposed that the association is particularly present in neovascular macular degeneration (5).

In this paper the relation between smoking status and quantity, and type of macular degeneration is explored in data of the population based Rotterdam Study in which, besides an extensive ophthalmological examination, current and past smoking habits were assessed by interview in 6825 participants.
\end{abstract}

\section{METHODS}

The Rotterdam Study is a single centre prospective follow-up study of the total population aged 55 years and over, of the city district of Ommoord, Rotterdam, The Netherlands. The study has been approved by the Medical Ethics Committee of Erasmus University. Rationale and design of the study have been described elsewhere (8). In brief, the objective of the study is to investigate prevalence, incidence and determinants of chronic ophthalmological, neurological, cardiovascular and locomotor diseases. Eligible were 10275 subjects, of whom $7983(78 \%)$ participated in the study. All participants gave a written informed consent. Baseline data were obtained in a home visit with interview followed by a physical examination in the field centre. Participants living in elderly homes were examined at their home. In the first 357 participants no ophthalmological examination was performed. In the present study we included data of all 7626 participants who were examined between March 1990 and the end of the baseline study in July 1993. Of the 7626 participants, 6825 (88\%) participated in the ophthalmological examination.

Eyes were dilated with tropicamide $0.5 \%$ and phenylephrine $5 \%$. After an average period of 45 minutes two $35^{\circ}$ colour photographs (Kodak Ektachrome 64 ASA, Topcon TRV-50VT fundus camera) centred on the macular area were taken of each eye. Photographs were graded using the definitions and grids of the Wisconsin Age-Related Maculopathy Grading System (WARMGS)(9) by one of three graders. Macular degeneration was diagnosed if either atrophic or neovascular macular degeneration was present in at least one eye. Atrophic macular degeneration, or geographic atrophy, was defined as any well demarcated 


\section{Chapter 6}

area of retinal pigment epithelium atrophy with visible choroidal vessels without the presence of neovascular macular degeneration. Neovascular macular degeneration was defined as the presence of serous or haemorrhagic retinal pigmentepithelial detachments, choroidal neovascular membranes or subretinal fibrous scars. Lesions that we considered to be the consequence of photocoagulation, chorioretinitis, trauma and congenital diseases were not included in the grading.

During an interview cigarette smoking (never, former, current) was determined. Former and current smokers were asked for age at first smoking, number of years of smoking and number of cigarettes smoked per day. Pack-years were calculated as the number of years smoked times the number of cigarettes smoked per day divided by 20 . The time since quitting smoking was estimated as current age minus age of first smoking plus years of smoking.

Atherosclerosis in the arteries of the lower extremities was studied by the ratio of the systolic blood pressure at the ankle to the systolic blood pressure at the arm. The ankle-arm index was calculated for each leg, the lowest index was used in the analysis (9-11) According to the criteria proposed by Fowkes et al. (11), and by Schroll and Munck (12), an ankle-arm index lower than 0.90 on at least one side was used to select a group with a high probability of having lower extremity atherosclerosis.

The study included 6251 persons in whom fundus photographs for one or both eyes were gradable. Data for smoking behaviour (never, former, current) and pack-years were available for 6174 (99\%) and 5929 (96\%) participants, respectively. The relation between smoking characteristics and macular degeneration was analyzed using multiple logistic regression analysis. Odds ratios with 95 percent confidence intervals $(95 \% \mathrm{CI})$ were calculated to assess the relative risk of macular degeneration, with the presence of macular degeneration as dependent variable and smoking characteristics as independent variables, adjusted for age and gender. The reference group was formed by those who had never smoked $(n=2356)$. The number of pack-years and the number of years since quitting smoking were divided into subgroups with boundaries at ten years intervals.

\section{RESULTS}

In 104 persons (1.7\%) macular degeneration was present, the prevalence increased from 1.1 percent below 85 years, to 11.0 percent in subjects aged 85 years and over. The average age of cases was 80.2 years with an age range of 57.8 to 96.5 years.

Former and current smokers younger than 85 years of age, had a two and four times higher risk of macular degeneration respectively, than those who had never smoked (Table 1). This association was not present in persons aged 85 years and 


\section{Smoking and $A M D$}

over. In the younger age group, current and former smoking was particularly associated with neovascular macular degeneration (Table 2). Atrophic macular degeneration appeared not to be associated with former smoking (Table 2). A strong increased risk of neovascular macular degeneration was present in persons who had smoked 10 or more pack-years (Table 3). To assess the possible mediating role of atherosclerosis, ankle arm systolic blood pressure index was entered as a covariate in the logistic regression model. This did not change the relation between smoking and macular degeneration (Table 3). A strong increased risk of neovascular macular degeneration was present in current smokers, and former smokers who stopped less then 20 years before eye examination (Table 4).

Table 1. Smoking status and macular degeneration in two age strata.

\begin{tabular}{|c|c|c|c|c|c|c|c|c|c|}
\hline \multirow{3}{*}{ Smoking } & \multicolumn{3}{|c|}{$55-84$ years } & \multicolumn{3}{|c|}{85 years and over } & \multicolumn{3}{|c|}{ All ages } \\
\hline & $\begin{array}{r}\text { Mac } \\
\text { degene } \\
\text { Num }\end{array}$ & $\begin{array}{l}\text { ular } \\
\text { eration } \\
\text { nber) }\end{array}$ & Relative risk ${ }^{\circ}$ & $\begin{array}{r}\text { Mas } \\
\text { degen } \\
\text { (Nur }\end{array}$ & $\begin{array}{l}\text { cular } \\
\text { eration } \\
\text { mber) }\end{array}$ & $\begin{array}{l}\text { Relative } \\
\text { risk }^{\circ}\end{array}$ & $\begin{array}{r}\text { Mac } \\
\text { degen } \\
\text { (Nun }\end{array}$ & $\begin{array}{l}\text { cular } \\
\text { leration } \\
\text { mber) }\end{array}$ & $\begin{array}{l}\text { Relative } \\
\text { risk }^{*}\end{array}$ \\
\hline & Present & Absent & & Present & Absent & & Present & Absent & \\
\hline Number & 68 & 5797 & & 33 & 276 & & 101 & 6073 & \\
\hline Never & 20 & 2118 & $1.0^{\dagger}$ & 25 & 193 & $1.0^{\dagger}$ & 45 & 2311 & $1.0^{t}$ \\
\hline Former & 27 & 2427 & $2.0(1.0-3.7)$ & 7 & 61 & $1.0(0.4-2.5)$ & 34 & 2488 & $1.6(0.9-2.6)$ \\
\hline Current & 21 & 1252 & $4.0(2.0-7.8)$ & 1 & 22 & $0.4(0.1-3.2)$ & 22 & 1274 & $2.6(1.5-4.8)$ \\
\hline
\end{tabular}

" adjusted for age and gender

$\dagger$ reference

Table 2. Smoking status and risk of macular degeneration, by type of macular degeneration in persons younger than 85 years.

\begin{tabular}{lccccccc}
\hline \multirow{2}{*}{ Smoking } & \multicolumn{2}{c}{ Atrophic macular degeneration } & & \multicolumn{2}{c}{ Neovascular macular degeneration } \\
\cline { 2 - 3 } \cline { 6 - 8 } & Present & Absent & $\begin{array}{c}\text { Relative risk } \\
(95 \% \mathrm{CI})\end{array}$ & Present & Absent & $\begin{array}{c}\text { Relative risk } \\
(95 \% \mathrm{CI})\end{array}$ \\
\hline Number & 26 & 5797 & & 42 & 5797 & \\
Never & 10 & 2118 & $1.0^{\dagger}$ & 10 & 2118 & $1.0^{\dagger}$ \\
Former & 9 & 2427 & $0.9(0.3-2.5)$ & 18 & 2427 & $3.2(1.4-7.4)$ \\
Current & 7 & 1252 & $1.9(0.7-5.4)$ & 14 & 1252 & $6.6(2.8-15.9)$ \\
\hline
\end{tabular}

* adjusted for age and gender

$\uparrow$ reference 


\section{Chapter 6}

Table 3. Number of pack-years and risk of neovascular macular degeneration in persons younger than 85 years.

\begin{tabular}{|c|c|c|c|c|}
\hline \multirow[t]{2}{*}{ Pack-years } & \multicolumn{2}{|c|}{$\begin{array}{c}\text { Neovascular macular } \\
\text { degeneration }\end{array}$} & \multirow{2}{*}{$\begin{array}{l}\text { Relative risk' } \\
\quad(95 \% \mathrm{CI})\end{array}$} & \multirow{2}{*}{$\begin{array}{l}\text { Relative risk }^{\dagger} \\
(95 \% \mathrm{CI})\end{array}$} \\
\hline & Present & Absent & & \\
\hline Number & 42 & 5582 & & \\
\hline Never smoked & 10 & 2129 & $1.0^{\ddagger}$ & $1.0^{\ddagger}$ \\
\hline $1-9$ & 5 & 902 & $2.1(0.7-6.2)$ & $2.6(0.8-8.2)$ \\
\hline $10-19$ & 8 & 609 & $7.1(2.6-19.0)$ & $9.1(3.2-25.9)$ \\
\hline $20-29$ & 7 & 569 & $8.6(3.0-24.8)$ & $9.9(3.5-32.6)$ \\
\hline 30 or more & 12 & 1373 & $5.7(2.2-14.5)$ & $4.7(1.8-14.6)$ \\
\hline
\end{tabular}

* adjusted for age and gender

$\dagger$ adjusted for age, gender and ankle-arm systolic blood pressure index

$\$$ reference

Table 4. Smoking and risk of neovascular macular degeneration in persons younger than 85 years.

\begin{tabular}{lccc}
\hline Years since cessation & \multicolumn{2}{c}{$\begin{array}{c}\text { Neovascular macular } \\
\text { degeneration }\end{array}$} & $\begin{array}{c}\text { Relative risk } \\
(95 \% \mathrm{CI})\end{array}$ \\
\cline { 2 - 3 } & Present & Absent & \\
\hline Number & 41 & 5550 & \\
Never smoked & 10 & 2118 & $1.0^{\dagger}$ \\
20 years or more & 4 & 1049 & $1.5(0.4-4.9)$ \\
$10-19$ years & 5 & 606 & $4.2(1.3-13.3)$ \\
1.9 years & 8 & 525 & $7.2(2.7-19.4)$ \\
Current smoking & 14 & 1252 & $6.5(2.7-15.6)$ \\
\hline
\end{tabular}

* adjusted for age and gender

$\dagger$ reference 


\section{Smoking and $A M D$}

\section{COMMENT}

In this study current and former smoking was associated with an increased risk of neovascular macular degeneration. The excess risk was present in persons younger than 85 years of age and remained present up to 20 years after quitting, independent of the presence of atherosclerosis. Our data are consistent with previous publications on this issue (2-5), and confirm the observation of Klein et al. that the association is particularly present for neovascular macular degeneration (5). The relation between the length of the period since smoking cessation and neovascular macular degeneration has not been reported before.

Before we accept these findings some methodological issues have to be addressed. Smoking behaviour was assessed by interview and differential misclassification could have occurred if cases were more likely to remember smoking habits than controls. We have, however, no reason to believe that this is the case.

The calculation of the period since the last cigarette was based on the assumption that during the period of smoking, no large stopping periods had occurred. Occasionally this could have led to an overestimation of the smoking period and, as a result, an underestimation of the period since quitting. The observation that the effect of smoking appears to diminish after 20 years cessation may therefore be underestimated.

The etiology of the association is still unclear, but several mechanisms could play a part. It is plausible that, by reducing serum antioxidants (13-16), smoking has a lowering effect on retinal antioxidants. These are present in the retina to protect it against oxygen radicals formed during light exposure $(17,18)$. Recently, low serum antioxidant levels were reported in cases with neovascular macular degeneration, independent of smoking (4). Several other pathways could be involved in the association, including alteration of the choroidal blood flow (20). We studied the possibility of atherosclerosis as an intermediate. The ankle arm index adjusted analysis suggests smoking to be an independent risk factor of macular degeneration. However, this reflects an indicator of relatively advanced generalized atherosclerosis and more moderate localized atherosclerosis may still be involved.

In conclusion this study adds to the evidence that smoking is a risk factor of neovascular age-related macular degeneration. The mechanism remains to be elucidated but our results tentatively suggest the association to be independent of atherosclerosis. 


\section{Chapter 6}

\section{REFERENCES}

1. Leibowitz H, Krueger DE, Maunder LR et al. The Framingham Eye Study Monograph; an ophthalmological and epidemiological study of cataract, glaucoma, diabetic retinopathy, macular degeneration, and visual acuity in a general population of 2631 adults, 1973-1977. Surv Ophthalmol. 1980;24:335-610.

2. Hyman LG, Lilienfeld AM, Ferris FL, Fine SL. Senile macular degeneration: a case control study. Am J Epidemiol, 1983;118:213-27.

3. Vinding T, Appleyard $M$, Nyboe J. Risk factor analysis for atrophic and exudative age-related macular degeneration. Acta Ophthalmol. 1992;70:66-72.

4. The Eye Disease Case-Control Study Group. Risk factors for neovascular age-related macular degeneration. Arch Ophthalmol. 1992;110:1701-8.

5. Klein R, Klein BE, Linton KL, DeMets DLA. The Beaver Dam Eye Study: the relation of age-related maculopathy to smoking. Am J Epidemiol. 1993;137:190-200.

6. Kahn HA, Leibowitz HM, Ganley JP, et al. The Framingham Eye Study II. Association of ophthalmic pathology with single variables previously measured in the Framingham Heart Study. Am J Epidemiol. 1977;106:33-41.

7. West SK, Rosenthal FS, Bressler NM et al. Exposure to sunlight and other risk factors for age-related macular degeneration. Arch Ophthalmol. 1989;107:875 9 .

8. Hofman A, Grobbee DE, Jong PTVM de, Ouweland FA van den. Determinants of diseaze and disability in the elderly: the Rotterdam Elderly Study. Eur J Epidemiol. 1991;7:403-22.

9. Bots ML, Swieten JC van, Breteler MMB et al. Cerebral white matter lesions and atherosclerosis in the Rotterdam Study. Lancet. 1993;341:1232-7.

10. Vogt MT, Wolfson SK, Kuller LH. Lower extremity arterial disease and the ageing process: A review. J Clin Epidemiol. 1992;45:529-42.

11. Fowkes FGR, Houseley E, Cawood EHH, Macintyre CCA, Ruckley CV, Prescott RJ. Edinburgh artery study: Prevalence of asymptomatic and symptomatic peripheral arterial disease in the general population. Int $J$ Epidemiol. 1991;20:384-92.

12. Schroll $M$, Munck $O$. Estimation of peripheral arteriosclerotic disease by ankle blood pressure measurements in a population of 60 year old men and women. J Chronic Dis. 1981;34:261-9.

13. Pryor WA, Hales BJ, Premovic PI, Church DF. The radicals in cigarette tar: their nature and suggested physiological complications. Science. 1983;220:425-7.

14. Stryker WS, Kaplan LA, Stein EA, Stampfer MJ, Sober A, Willett WC. The relation of diet, cigarette smoking, and alcohol consumption to plasma betacarotene and alpha-tocopherol levels. Am J Epidemiol, 1988;127:283-96.

15. Sanders TA, Haines AP, Wormald R, Wright LA, Obeid O. Essential fatty 


\section{Smoking and AMD}

acids, plasma cholesterol, and fat-soluble vitamins in subjects with age-related maculopathy and matched control subjects. Am J Clin Nutr. 1993;57:428-33.

16. Schectman G, Byrd GC, Gruchow HW. The influence of smoking on vitamin C status in adults. Am J Public Health. 1989;79:158-62.

17. Handelman GJ, Dratz EA, Reay CC, van Kuijk FJGM. Carotenoids in the human macular and whole retina. Invest Ophthalmol Vis Sci. 1988;29:850-5.

18. Krinsky NI. Antioxidant functions of carotenoids. Free Radic Biol Med. 1989;7:617-37.

19. Bettman JW, Fellows V, Chao $P$. The effect of cigarette smoking on the intraocular circulation. Arch Ophthalmol, 1958;59:481-3.

20. Friedman E. Choroidal blood flow. Arch Ophthalmol. 1970;83:95. 


\title{
IS AGE-RELATED MACULAR DEGENERATION ASSOCIATED WITH EARLY MENOPAUSE?
}

\begin{abstract}
Age-related macular degeneration is a major cause of blindness in the elderly. The disease affects the macula lutea and results in a central scotoma in the visual field. The aetiology of the disease is poorly understood, and treatment is only successful in a minority of cases.

Recent findings of an association between use of postmenopausal exogenous oestrogens and a lower risk of macular degeneration suggest a role for oestrogens in the pathogenesis of the disease (1). We addressed this issue by hypothesizing a higher risk of macular degeneration in women with early menopause.
\end{abstract}

\section{METHODS AND RESULTS}

Data were obtained from the Rotterdam Study (2). All residents aged 55 year and over, of the suburb of Ommoord, Rotterdam, The Netherlands, were invited for the study. The response rate among women was $78 \%(\mathrm{~N}=4616)$. Macular degeneration was scored present if either atrophic or neovascular age-related macular degeneration was visible on colour fundus transparencies. Age and type of menopause was self-reported, and checked by a study physician. The cause of menopause was classified as natural, hysterectomy, oophorectomy and/or hysterectomy without respect to the number of ovaries removed, radiation therapy, or the use of drugs. For 3680 women (80\%) gradable fundus photographs of at least one eye, and complete menopause data were available. Macular degeneration was present in 59 women (1.6\%). Each case was matched with five controls without macular degeneration in the same one-year age group, resulting in 295 controls. Relative risks with $95 \%$ confidence intervals were calculated using conditional logistic regression analysis.

The table shows the relative risk of macular degeneration according to age and type of menopause. No significant excess risk was found for early spontaneous menopause and early hysterectomy. Women with early menopause after an operation with removal of one or both ovaries had a significantly increased risk of macular degeneration compared to women who had their menopause at 45 years or later (relative risk 3.8;95\% confidence interval 1.1-12.6). Of 16 women who had menopause by oophorectomy at 45 years or later, none had macular degeneration. This indicates a significant excess risk of early compared to late menopause by oophorectomy (exact lower $95 \%$ confidence limit 1.7 ). 
Relative risk of macular degeneration by type of menopause.

\begin{tabular}{|c|c|c|c|c|}
\hline & \multicolumn{2}{|c|}{$\begin{array}{c}\text { Macular } \\
\text { degeneration }\end{array}$} & \multirow[b]{2}{*}{$\mathrm{RR}^{*}$} & \multirow[b]{2}{*}{$95 \% \mathrm{CI}^{\dagger}$} \\
\hline & Absent & Present & & \\
\hline Menopause $\geq 45$ years & 253 & 45 & 1.0 & reference \\
\hline Menopause $<45$ years & 42 & 14 & 1.9 & $(1.0-3.8)$ \\
\hline Spontaneous & 30 & 6 & 1.2 & $(0.5-3.3)$ \\
\hline \multicolumn{5}{|l|}{ Surgical } \\
\hline Hysterectomy only & 4 & 1 & 2.1 & $(0.2-24.9)$ \\
\hline Uni- or bilateral oophorectomy ${ }^{\ddagger}$ & 6 & 5 & 3.8 & $(1.1-12.6)$ \\
\hline Irradiation & 1 & 2 & 4.2 & $(0.6-30.2)$ \\
\hline Other & 1 & 0 & $\S$ & \\
\hline
\end{tabular}

* $\quad R R=$ relative risk, adjusted for age.

$\dagger 95 \% \mathrm{CI}=95$ percent confidence interval.

$\neq$ Oophorectomy with or without hysterectomy.

$\S$ One women reported early cessation of menses after usage of drugs. The relative risk was not calculated because of the small numbers.

\section{DISCUSSION}

Our findings suggest that early artificial menopause increases the risk of macular degeneration and are compatible with the view that oestrogens play a role in the pathogenesis of the disease (1).

The association between early artificial menopause and macular degeneration may be related to an early marked decline of oestrogen production or, alternatively, to factors related to the operation or irradiation. The absence of an increased risk of macular degeneration associated with oophorectomy at 45 years or later speaks against the latter and favours an association with the arrest of oestrogen production. Combining uni- and bilateral oophorectomy may have resulted in an underestimation of this effect. No association with early spontaneous menopause was observed. The mean age of early spontaneous menopause was similar to mean age of early medically induced menopause. Possibly, the absence of the effect is due to a gradual decline of oestrogen production in natural menopause. Furthermore, the results may be affected by misclassification since women tend to underestimate the age of spontaneous cessation of the menses.

The mechanism of the association is unknown. Previous studies suggested that surgical menopause with removal of both ovaries increases the risk of 


\section{Chapter 7}

cardiovascular disease and atherosclerosis (3-5). Possibly, similar factors are underlying the development of macular degeneration.

Confirmation of our findings in larger studies is awaited. 


\section{REFERENCES}

1. The Eye Disease Case-Control Study Group. Risk factors for neovascular agerelated macular degeneration. Arch Ophthalmol 1992;110:1701-8.

2. Hofman A, Grobbee DE, de Jong PTVM, van den Ouweland FA. Determinants of disease and disability in the elderly: the Rotterdam Elderly Study. Eur J Epidemiol 1991;7:403-22.

3. Colditz GA, Willett WC, Stampfer MJ, Rosner B, Speizer FE, Hennekens CH. Menopause and the risk of coronary heart disease in women. N Eng J Med 1987;316:1105-10.

4. Witteman JCM, Grobbee DE, Kok FJ, Hofman A, Valkenburg HA. Increased risk of atherosclerosis in women after the menopause. $\mathrm{Br}$ Med $\mathrm{J}$ 1989;298:642-4.

5. Palmer JR, Rosenberg L, Shapiro S. Reproductive factors and risk of myocardial infarction. Am J Epidemiol 1992;136:408-16. 


\section{CHAPTER 8}

\section{GENERAL DISCUSSION}

In this thesis several studies on frequency and risk factors of ARM are described. This chapter will focus on the methodology, main outcomes and clinical relevance of these studies. Finally, suggestions will be given for future research.

\section{METHODOLOGICAL ISSUES}

\section{Study design}

The studies described in this thesis are based on the baseline data of the Rotterdam Study. The baseline study was cross-sectional and it therefore provides information about the frequency and characteristics of a disease in a certain population at a specified time. This design is suitable for a study of the prevalence of ARM.

The study of risk factors for a disease in cross-sectional data is hampered by the fact that both the risk factor and the disease are assessed at the same point in time. The observed associations often raise the dilemma whether the exposure preceded, or resulted from the disease. The cross-sectional design is therefore useful suggesting the presence of an association. However, it can also provide evidence of a causal association for several factors that remain unaltered during life, or for those that are likely to be present long before the disease occurred. The risk factors that are studied in this thesis are likely to have preceded the disease. Atherosclerosis, for example, is a slowly cumulative process that is present several years before AMD becomes manifests. This situation is similar for smoking and menopause. In a temporal sense, it is therefore conceivable that there is a causal relationship between these risk factors and AMD.

\section{Accuracy}

Several sources of error that could influence the results need to be considered. The main problem in a prevalence is non-participation. It is likely that nonparticipants to the study has influenced the prevalence estimates. Probably an underestimation of the true prevalence of ARM in this population has occurred since non participants are more likely to be diseased.

Whether non-participation has led to selection bias is a matter of discussion. For example, if smokers with AMD are more willing to participate than nonsmokers with AMD, then a spurious association would have been found between smoking and $\mathrm{AMD}$, even if there was none. We have no reason to believe, however, that this was the case. The overall high response to the study limits the amount of possible bias. Furthermore, the results of this study would only be seriously affected if the associations would be strongly opposite in non- 


\section{General discussion}

responders, which is not likely.

If the results are used to estimate the frequency of a disease in another population, for example the general population, several factors need to be considered. Ideally, the study population is the general population with $100 \%$ participation. It is clear that these criteria are never met. The population of the Rotterdam Study consists of a mainly white population of middle-class socioeconomic status, including the residents of the homes for the elderly. Extrapolation of the results to the general population may therefore be possible, though caution is needed.

Information bias may occur when differences are present in the way in which data are obtained in cases and controls. Both investigator and participant can be involved in this type of bias. Atherosclerosis, however, was assessed irrespective of the level of visual acuity and without knowledge of a possible association. Smoking behaviour and menopause data were obtained by interview and bias could have occurred if the interviewer was preoccupied with knowledge about an association between these determinants and AMD or if patients are more likely to recall these than controls. Interviewers and patients, however, were not aware of these possible associations which makes this kind of bias unlikely to have occurred.

Confounding can occur when a extraneous factor is associated with the determinant under study as well as with the outcome. To exclude the possibility of confounding one needs to know more about the etiology of the disease. As little is known about the etiology of ARM, it is difficult to exclude the possibility of confounding. The most important confounder is age.

Precision corresponds to the amount of random error in a study, and is related to the statistical power of a study to detect existing relationships. The grading of ARM was performed by grading of fundus photographs. More extensive examination with use of fluorescein angiography and dual grading of the photographs could have enhanced precision. However, without these methods it is likely that misclassification has occurred causing a less precise assessment of those who have the disease and those who have not. As misclassification occurs in both cases and controls, a dilution of the association can be expected, causing an underestimation of the true risk. The large size of the Rotterdam Study minimizes this problem.

\section{RISK FACTORS}

Age

As the term indicates, age-related maculopathy is highly associated with age. The relation with age was observed in all previous prevalence studies of age-related maculopathy (1-6). Our study shows an almost exponential increase of prevalence in persons aged 75 years and over. If one would live long enough, age-related 


\section{Chapter 8}

maculopathy possibly develops in all persons due to the ongoing ageing process. Exposures that accumulate with age, however, possibly enhance the normal ageing process.

\section{Gender}

In one prevalence study, women have been found to have a somewhat higher prevalence of neovascular AMD than men (6). Whether this reflects a difference in incidence rate is not known. We found no relation between gender and neovascular AMD. The prevalence of pigmentary changes was higher among men than women, however. This relation has previously been described (6). The etiology is unknown.

\section{Atherosclerosis}

One of the hypotheses for the pathogenesis of age-related maculopathy is that due to vascular disease, an alteration of the choriocapillaris occurs, decreasing the flow or passage of nutrients (7-9); however, not all authors agree with this theory (10). The issue was examined in various ways, either by using blood pressure measurements or history data of cardiovascular disease. Conflicting reports were published about the association between age-related maculopathy and a history of cardiovascular disease: several case-control studies found a positive association (11-13), whereas others did not (14-16). These studies suggest that an association with age-related maculopathy might exist. We found an association between indicators of atherosclerosis and macular degeneration. Although it is conceivable that atherosclerosis has an effect on the function of the retina it has not been described before. In part this may be the result of a lack of measures to assess atherosclerosis in vivo. Further, the knowledge about the pathology of the disease is based on autopsied eyes which are mostly derived from the very old. In the oldest age-category we did not observe an association with atherosclerosis possibly because all subjects are already affected.

\section{Smoking}

An increased risk of age-related macular degeneration (AMD) was first mentioned by Hyman et al. in male smokers (11) and confirmed in several studies later (16$18)$, although not uniformly $(19,20)$. The association with smoking was particularly present in neovascular AMD (18). We observed for the first time a dose-response relationship and an increased risk in those who were smoking up to 20 years before examination. The pathogenetic effect of smoking is still unclear but it could act in several ways. Smoking negatively affects serum anti-oxidant levels which in turn may result in a lower level of antioxidants in the retina. Further it is possible that smoking has an effect on the choroidal flow thereby interfering with the homeostasis in that area. 


\section{General discussion}

\section{Menopause}

The association with menopause was not described before. In women using postmenopausal exogenous oestrogens, however, a lower risk for macular degeneration was described (16). We found an increased risk of macular degeneration in women with early artificial menopause. The results suggest a role of oestrogens in the etiology of the disease. Oestrogens may affect the flow, may have a direct effect on the vessel walls and may be related to atherosclerosis.

\section{CLINICAL RELEVANCE}

By extrapolation of the prevalence data of the Rotterdam Study to the present Dutch population (21), it can be estimated that 19800 persons suffer from atrophic or neovascular AMD in one or both eyes in the Netherlands. The relevance of the relation between cardiovascular risk factors and AMD for the individual may be small, the effect on population level can be of major importance. The currently suggested interventions concerning risk factors for atherosclerosis may have a lowering effect on the incidence of AMD in the future. Smoking is still very common, it is a major risk factor and amenable to prevention. The effect of antismoking campaigns may become evident in the next decades. Quitting smoking by persons with early stages of ARM may show to be preventive on the development of neovascular AMD. The effect of early oophorectomy is likely to be small since at present bilateral oophorectomy is infrequently performed and if it is done oestrogen suppletion is given.

\section{FUTURE RESEARCH}

Most of our knowledge about the etiology of ARM is based on cross-sectional data. Prospective follow-up studies would provide important information on the incidence and risk factors for ARM. Further, these studies would add to a better understanding of drusen and pigmentary changes and their role in ARM. A major part of this thesis is based on the relation of cardiovascular risk factors to AMD. Since the outcome of these studies suggest an important role for these factors it is worthwhile to investigate them in more detail. More scientific research of these risk factors in the basic sciences might elucidate the pathways in which they may cause the association. The relation between AMD and atherosclerosis needs more attention, especially in histopathological studies. Further research on risk factors of drusen and retinal pigment epithelium changes is needed to clarify their etiology. The effect of atherosclerosis and smoking on the progression of drusen and retinal pigment epithelium changes deserves special attention in follow-up studies. Possibly there is a genetical component in ARM. More extensive research is needed to evaluate the magnitude of the genetic component and mode of 


\section{Chapter 8}

inheritance. Localization of the genes will lead to a better understanding of the underlying causes of ARM, and identification of family members at risk will provide the basis for future therapeutic and preventative interventions. 


\section{General discussion}

\section{REFERENCES}

1. Leibowitz H, Krueger DE, Maunder LR, Milton RC, Kini MM, Kahn HA, Nickerson RJ, Pool J, Colton TL, Ganley JP, Loewenstein JI, Dawber TR. The Framingham Eye Study Monograph; an ophthalmological and epidemiological study of cataract, glaucoma, diabetic retinopathy, macular degeneration, and visual acuity in a general population of 2631 adults, 19731977. Surv Ophthalmol 1980;24:335-610.

2. Martinez GS, Campbell AJ, Reinken J, Allan BC. Prevalence of ocular disease in a population study of subjects 65 years old and older. Am J Ophthalmol 1982;94:181-9.

3. Jonasson $F$, Thordarson $\mathrm{K}$. Prevalence of ocular disease and blindness in a rural area in the eastern region of Iceland during 1980 through 1984. Acta Ophthalmol 1987;65(suppl);40-3.

4. Vinding T. Age-related macular degeneration. Macular changes, prevalence and sex ratio. Acta Ophthalmol 1989;67;609-16.

5. Bressler NM, Bressler SB, West SK, Fine SL, Tayler HR. The grading and prevalence of macular degeneration in Chesapeake Bay watermen. Arch Ophthalmol 1989;107:847-52.

6. Klein R, Klein BEK, Linton KLP: Prevalence of age-related maculopathy. The Beaver Dam Eye Study. Opthalmol 1992;99:933-42.

7. Verhoeff FH, Grossman HP. Pathogenesis of disciform degeneration of the macula. Arch Ophthalmol 1937;18:561-85.

8. Gass JDM: Pathogenesis of disciform detachment of the neuroepithelium III Senile disciform macular degeneration. Am J Ophthalmol 1967;63:573-711.

9. Kornzweig AL. Changes in the choriocapilaris associated with senile macular degeneration. Ann Ophthalmol 1977;9:753-64.

10. Green WR, Key SN. Senile macular degeneration: a histopathologic study. Trans Am Ophthalmol Soc 1977;75:180-254.

11. Hyman LG, Lilienfeld AM, Ferris FL, Fine SL. Senile macular degeneration: a case control study. Am J Epidemiol 1983;118:213-27.

12. Delaney WV, Oates RP. Senile macular degeneration: a preliminary study. Ann Ophthalmol 1982;14:21-4.

13. Vidaurri JS, Pe'er J, Halfon ST, Halperin G, Zauberman H. Association between drusen and some risk factors for coronary artery disease. Opthalmologica 1984;188:243-7.

14. Maltzman BA, Mulvihill MN, Greenbaum A. Senile macular degeneration and risk fators: a case-control study. Ann Ophthalmol 1979;1197-201.

15. Blumenkranz MS, Russell SR, Robey MG, Kott-Blumenkranz R, Penneys $\mathrm{N}$. Risk factors in age-related maculopathy complicated by choroidal neovascularization. Ophthalmology 1986;93;552-8.

16. The Eye Disease Case-Control Study Group: Risk factors for neovascular age-related macular degeneration. Arch Ophthalmol 1992;110:1701-8. 


\section{Chapter 8}

17. Vinding T, Appleyard M, Nyboe J. Risk factor analysis for atrophic and exudative age-related macular degeneration. Acta Ophthalmol 1992;70:66-72.

18. Klein R, Klein BE, Linton KL, DeMets DLA. The Beaver Dam Eye Study: the relation of age-related maculopathy to smoking. Am J Epidemiol 1993;137:190-200.

19. Kahn HA, Leibowitz HM, Ganley JP, et al. The Framingham Eye Study II. Association of ophthalmic pathology with single variables previously measured in the Framingham Heart Study. Am J Epidemiol 1977;106:33-41.

20. West SK, Rosenthal FS, Bressler NM, Bressler SB, Muñoz B, Fine SL, Taylor HR. Exposure to sunlight and other risk factors for age-related macular degeneration. Arch Ophthalmol 1989;107:875-9.

21. Abrahamse APJ. Centraal Bureau voor de Statistiek. Statistisch jaarboek 1994. SDU Uitgeverij, The Hague, The Netherlands, 1994. 


\section{CHAPTER 9}

\section{SUMMARY}

Age-related maculopathy is the major cause of severe visual impairment in the elderly. The disease affects the centre of the retina, causing a blind spot central in the visual field. The possibilities for treatment are limited to a small group of patients and even in this group the success of treatment is limited. This thesis focuses on epidemiologic studies on age-related maculopathy.

In chapter 2 the current epidemiologic knowledge about age-related maculopathy concerning the frequency, risk factors, prognosis and treatment of the disease are reviewed. The prevalence of macular degeneration, the end-stage of age-related maculopathy, rises strongly with age. Several risk factors were found previously of which age is still the most important.

Chapter 3 describes the results of a series of meetings among six groups involved in epidemiological studies of macular degeneration with the aim to develop a core grading system using colour stereoscopic fundus transparencies to classify age-related maculopathy.

In chapter 4 the prevalence of age-related maculopathy in the Rotterdam Study is described. The results are based on the grading of fundus photographs of 6,251 participants of the Rotterdam Study, aged 55 to 98 years. The prevalence of small abnormalities that are believed to be associated with macular degeneration was high: at least one drusen of $63 \mu \mathrm{m}$ or larger was present in $40.8 \%$ in persons aged $55-64$ year to $52.6 \%$ in those aged 85 years or older. In the same age-groups, the prevalence of drusen of $125 \mu \mathrm{m}$ or larger increased from $4.8 \%$ to $17.5 \%$, retinal pigment epithelial hypopigmentations from $3.5 \%$ to $9.0 \%$ and increased retinal pigment from $3.7 \%$ to $15.3 \%$. Age-related macular degeneration was present in $1.7 \%$ of the total population. Atrophic macular degeneration increased from $0.1 \%$ in persons aged $55-64$ years to $3.7 \%$ in those aged 85 years or over. Neovascular macular degeneration increased from $0.1 \%$ to $7.4 \%$ in these age groups. These findings suggest that age-related maculopathy may be less common in this population than in similar populations in the USA.

In chapter 5 the results are presented from a study on the association between atherosclerosis and the late stages of the disease, atrophic and neovascular agerelated macular degeneration. The association between atherosclerosis and this type of macular degeneration was studied in 104 subjects with and 1324 subjects without macular degeneration. Atherosclerosis of the carotid arteries was ultrasonographically evaluated by measurement of the common carotid intimamedia thickness and by assessment of presence of atherosclerotic plaques. Atherosclerosis in the arteries of the lower extremities was studied by determination of the ankle-arm systolic blood pressure ratio. In subjects younger than 85 years, plaques in the carotid bifurcation were associated with a 4.7 times increased risk of macular degeneration $(95 \%$ CI $1.8-12.2)$; those with plaques in 


\section{Chapter 9}

the common carotid artery showed an increased relative risk of $2.5(1.4-4.5)$. The intima-media thickness of the common carotid arteries was not significantly different. Lower extremity arterial disease (ankle-arm index less than 0.90 on at least one side) was associated with a 2.5 times increased risk for macular degeneration (1.4-4.5). These findings suggest that atherosclerosis may be involved in the aetiology of age-related macular degeneration.

In chapter 6 the relation between cigarette smoking and age-related macular degeneration was presented. Smoking behaviour was obtained by interview and atherosclerosis was assessed by ankle-arm systolic blood pressure index. In subjects younger than 85 years, current smokers had a 4.0 times increased risk of macular degeneration than those who had never smoked $(95 \%$ confidence interval 2.0-7.8). Former smokers had a 2.0 times higher risk of macular degeneration than non smokers in this age group (95\% CI 1.0-3.7). These associations were not observed in subjects aged 85 years or over. Smoking was particularly associated with neovascular macular degeneration. A strongly increased risk of neovascular macular degeneration was present in those who had smoked more than 10 packyears (relative risk $6.595 \%$ confidence interval 2.9-14.8). Adjustment for atherosclerosis did not change the association. Persons who had quitted smoking 20 or more years before the eye examination, had no excess risk. The results provide evidence for a dose-response relationship between smoking and agerelated macular degeneration, particularly in persons with the neovascular form of the disease.

In chapter 7 the relation between early menopause and age-related macular degeneration is studied. Fifty-nine cases and 295 age-matched controls aged 55 years and over were selected from the Rotterdam Study. Age and type of menopause were obtained in an interview. Spontaneous menopause was not associated with an increased risk for macular degeneration (RR $1.2 ; 95 \%$ CI 0.5 to 3.3). Women who had had a hysterectomy before the age of 45 years without removal of the ovaries, had a slightly, but not significantly, increased risk (RR $2.1 ; 95 \%$ CI 0.2 to 24.9 ). Women who had had an early menopause after an operation with removal of one or both ovaries, had a 3.8 times increased risk for macular degeneration (95\% CI 1.1 to 12.6$)$. Those who had had an early menopause after irradiation had also an increased risk of macular degeneration, though not significantly (RR $4.2 ; 95 \% \mathrm{CI} 0.6$ to 30.2 ). The results suggest that early iatrogenic menopause increases the risk of macular degeneration. The mechanism of the association may be similar to that of cardiovascular disease.

In chapter 8 some of the methodological issues involved in the studies of this thesis are discussed and the findings of these studies are reviewed. 


\section{SAMENVATTING}

Dit proefschrift omvat een aantal epidemiologische onderzoeken naar de frequentie en oorzaken van leeftijdgebonden maculopathie. Deze aandoening is de belangrijkste oorzaak van ernstige slechtziendheid bij ouderen. De ziekte tast het centrum van het netvlies aan waardoor er centraal in het gezichtsveld een blinde vlek optreedt. Behandeling van de ziekte is slechts mogelijk bij een kleine groep patiënten waarbij bovendien de kans op blijvend succes gering is.

Leeftijdgebonden maculopathie is een verzamelnaam waaronder de voor- en eindstadia van het ziektebeeld worden samengevat. De eindstadia zijn verantwoordelijk voor het verlies van gezichtsscherpte. In de nieuwe terminologie spreekt men bij de eindstadia van leeftijdgebonden macula degeneratie. Er worden twee soorten onderscheiden: de atrofische en neovasculaire macula degeneratie. Bij de atrofische macula degeneratie, ook wel droge macula degeneratie of geografische atrofie genoemd, treedt er centraal in de retina een afsterving op van het retinale pigment epitheel en de fotoreceptoren. In welke volgorde dit proces optreedt is onbekend. De neovasculaire macula degeneratie, ook wel disciforme, natte of exsudatieve macula degeneratie genoemd, is het gevolg van een vaatnieuwvorming centraal onder het netvlies. Het vat ontspringt uit het onderliggende vaatvlies en vertoont de neiging tot lekkage en bloeding. Door lekkage van de vaatnieuwvorming wordt de retina plaatselijk opgetild waardoor er vervorming (metamorphopsie) van het beeld ontstaat. Na bloeding vanuit een dergelijk vat ontstaat er een litteken centraal in het netvlies.

De voorstadia van leeftijdgebonden maculopathie vallen onder de noemer vroege leeftijdgebonden maculopathie. Deze afwijkingen worden in verband gebracht met een hoger risico op het ontstaan van macula degeneratie in de toekomst. Er worden twee afwijkingen onderscheiden: drusen en pigmentveranderingen. Drusen zijn gele vlekjes die bij het oogspiegelen zichtbaar zijn. De aantallen, de grootte en het aspect van drusen kunnen sterk variëren en omdat de betekenis voor het ontstaan van het eindstadium van de maculopathie onbekend is, wordt er een indeling gemaakt op basis van deze kenmerken. Grote aantallen grote drusen worden daarbij gezien als risicofactor voor macula degenerat:e. Kleine scherp begrensde drusen hebben vermoedelijk geen relatie met macula degeneratie. Lokale veranderingen in het retinale pigmentepitheel worden gezien als hyper- en/of fypopigmentaties. Ook deze afwijkingen worden in verband gebracht met een verhoogd risico op het verkrijgen van macula degeneratie.

In hoofdstuk 2 wordt een overzicht gegeven van de epidemiologische kennis op het gebied van de leeftijdgebonden maculopathie. De huidige inzichten betreffende definitie, frequentie, risico factoren, beloop en behandeling worden achtereenvolgens uiteengezet. De prevalentie van maculopathie neemt sterk toe 
met de leeftijd. Verscheidene risico factoren lijken een rol te spelen waarvan leeftijd de belangrijkste is. Andere factoren die in meerdere onderzoeken in verband worden gebracht met een hoger risico zijn hart-vaat ziekten, roken, zonlicht expositie, lichte iriskleur en positieve brilsterkte. Een verlaagd risico werd gevonden bij vrouwen met postmenopausaal oestrogeen gebruik. Bij aantasting van een oog bestaat er een grote kans dat het andere oog eveneens aangedaan zal worden. De behandeling bestaat sinds jaren uit lasercoagulatie van de vaatnieuwvorming order de retina. Onlangs zijn er nieuwe behandelings methoden beschreven waarvan de doeltreffendheid echter nog moet worden aangetoond.

Hoofdstuk 3 beschrijft een internationaal classificatie systeem van macula degeneratie. Deze classificatie is het resultaat is van een aantal ontmoetingen van zes onderzoeksgroepen die betrokken zijn bij epidemiologisch onderzoek van macula degeneratie. Deze classificatie werd ontwikkeld om de resultaten van verschillende onderzoeken beter te kunnen vergelijken.

In hoofdstuk 4 wordt het onderzoek naar de prevalentie van leeftijdgebonden maculopathie in het ERGO onderzoek beschreven. Ten behoeve van deze studie werden 6781 inwoners van de Rotterdamse wijk Ommoord in de leeftijd van 55 jaar of ouder uitgebreid oogheelkundig onderzocht. Het onderzoek omvatte een test van de . gezichtsscherpte, brilsterkte, oogdruk, gezichtsveld, spleetlamponderzoek en fotografie van de oogzenuw en het netvlies. Bij 6251 deelnemers was het mogelijk om dia's van goede kwaliteit te verkrijgen van het netvlies van een of beide ogen. De leeftijd van deze deelnemers varieerde van 55 tot 98 jaar. Maculopathie werd naderhand op de dia's vastgesteld. De frequentie van kleine drusen nam af met de leeftijd, vermoedelijk doordat ze minder goed zichtbaar worden door een toename van de troebelingen in de lens. De prevalentie van grote drusen nam sterk toe met de leeflijd. Veranderingen in het retinale pigmentepitheel gaven een zelfde toename te zien als de grote drusen. Bovendien kwamen ze vaker voor bij mannen dan bij vrouwen, waarvoor geen verklaring voorhanden is. De eindstadia atrofische en neovasculaire macula degeneratie werden vastgesteld bij $1.7 \%$ van de deelnemers. De frequentie nam sterk toe met de leeftijd. Van de deelnemers in de leeftijd van 85 jaar of ouder werd bij $3.7 \%$ atrofische macula degeneratie en bij $7.4 \%$ neovasculaire macula degeneratie vastgesteld. Deze frequenties zijn lager dan werd verwacht op grond van soortgelijk onderzoek in de Verenigde Staten.

In de volgende hoofdstukken van het proefschrift wordt het onderzoek naar de risicofactoren van de aandoening beschreven. Als patiëntengroep werden deelnemers van het ERGO onderzoek met het eindstadium macula degeneratie vergeleken met deelnemers zonder het eindstadium.

Hoofdstuk 5 presenteert de resultaten van het onderzoek naar de relatie met atherosclerotische vaatafwijkingen elders in het lichaam. Een verband met atherosclerose werd vermoed omdat het vaatvlies een van de weefsels is die een rol spelen bij macula degeneratie. Wel werd in eerdere onderzoeken een verhoogd 


\section{Samenvatting}

risico op macula degeneratie beschreven bij personen met cardiovasculaire aandoeningen. De huidige studie werd verricht op basis van gegevens van 104 deelnemers met, en 1324 deelnemers zonder macula degeneratie. De aanwezigheid van atherosclerose werd vastgesteld door het in beeld brengen van de halsslagaders met behulp van geluidsgolven techniek en bepaling van de enkelarm systolische bloeddruk index. Een enkel-arm index lager dan 0.90 aan een of beide kanten wordt gezien als een sterke aanwijzing voor atherosclerotische vaatwand veranderingen in de benen. Verder werd de aanwezigheid van atherosclerotische plaques in een of beide halsslagaders werd als maat genomen voor de aanwezigheid van atherosclerose. In personen jonger dan 85 jaar werd een verhoogd risico op macula degeneratie gevonden bij personen met een lage enkelarm index en de bij deelnemers met atherosclerotische plaques in een of beide halsslagaders. Deze relatie werd niet gevonden in personen in de leeftijd van 85 jaar of ouder. Het verband bleef aanwezig na correctie voor rookgedrag en verhoogde bloeddruk. De resultaten van het onderzoek suggereren dat atherosclerose een zelfstandige rol speelt in het ontstaan van macula degeneratie. Mogelijk doordat atherosclerose veranderingen in het vaatvlies tot gevolg heeft en de bloedstroom ter plaatse nadelig beïnvloedt.

In hoofdstuk 6 wordt de relatie met roken behandeld. In een aantal eerder onderzoeken werd een verhoogd risico op macula degeneratie beschreven bij rokers en ex-rokers. In het ERGO onderzoek werden de rookgewoontes tijdens een interview vastgesteld. De resultaten laten een toename zien van het risico op macula degeneratie bij een toename van de totale hoeveelheid gerookte sigaretten. Deze relatie was aanwezig bij personen onder de 85 jaar en met name bij personen met neovasculaire macula degeneratie. Ook bestond er een sterke relatie met de tijlsduur vanaf het stoppen met roken. Alleen rokers en ex-rokers die korter dan 20 jaar geleden gestopt waren hadden een verhoogd risico op neovasculaire macula degeneratie. De relatie bleef aanwezig na correctie voor het aantal ge vokte sigaretten en de aanwezigheid van atherosclerose. De resultaten suggerercn een dosis afhankelijke relatie met roken met name in personen met neovasculaire macula degeneratie. De achtergrond van de relatie is nog niet opgehelderd. Het is bekend dat roken de serum spiegels van anti-oxidanten verlaagd. Mogelijk verlaagt roken ook de concentratie van anti-oxidanten in het netvlies waardoor de daar bij belichting vrijkomende vrije radicalen minder snel zouden worden weggevangen.

In hoofdstuk 7 wordt het onderzoek naar de relatie met menopauze beschreven. De aanleiding voor dit onderzoek was een eerder onderzoek waarbij een lager risico op macula degeneratie bij vrouwen die postmenopausaal oestrogenen gebruikten, werd beschreven. Op basis hiervan verwachtten wij een hoger risico bij vrouwen die vroeg in de menopauze komen doordat bij hen de oestrogeen produktie eerder stopt. Het onderzoek betrof 59 vrouwen met, en 295 vrouwen van gelijke leeftijd zonder macula degeneratie. De leeftijd en de reden van menopauze werd tijdens een interview vastgesteld en gecontroleerd door een 


\section{Chapter 10}

ERGO-arts. Een vroege spontane menopauze en een vroege menopauze door verwijdering van alleen de baarmoeder waren niet geassocieerd met een verhoogd risico op macula degeneratie. Een vroege chirurgische menopauze met verwijdering van een of beide ovaria evenals een vroege menopauze na bestraling waren echter geassocieerd met een significant verhoogd risico op de aandoening. Deze resultaten komen overeen met het eerdere onderzoek en suggereren dat oestrogenen een rol kunnen spelen in de ontstaansgeschiedenis van de aandoening. Mogelijk speelt hierbij de invloed van oestrogenen op de vaatwand en het ontstaan van atherosclerose een rol.

Hoofdstuk 8 behandeld de opzet en de methodes van de onderzoeken die in dit proefschrift worden besproken. Verder worden de resultaten samengevat, en worden er suggesties gedaan voor toekomstig onderzoek. Op dit moment zijn er geen gegevens beschikbaar over het aantal nieuwe personen bij wie zich macula degeneratie ontwikkelt. Het vervolg-onderzoek van ERGO en enkele onderzoeken in het buitenland zullen hierop een antwoord kunnen gaan geven. Verder is het noodzakelijk dat de gevonden associaties ook in de basiswetenschappen worden onderzocht zodat er een bredere basis kan ontstaan voor eventuele preventieve adviezen. 


\section{NAWOORD}

Dit proefschrift werd geschreven onder de vleugels van de afdeling Oogheelkunde en het instituut Epidemiologie \& Biostatistiek van de Erasmus Universiteit Rotterdam. Medewerkers van beide afdelingen hebben hieraan een grote bijdrage geleverd. Een aantal hiervan wil ik hier noemen vanwege hun directe bijdrage aan mijn onderzoek.

Er zou geen promotie zijn zonder mijn promotor Paulus de Jong, initiator en begeleider van het oogheelkundig onderzoek in ERGO. Ondanks zijn drukke werkzaamheden was hij altijd bereikbaar en bereid om tijd vrij te maken. Zijn directe, intense manier van werken waardeer ik zeer, zijn bijdrage aan het onderzoek is moeilijk te overschatten.

Mijn tweede promotor, Bert Hofman, ben ik met name dank verschuldigd voor de wijze waarop hij mij bij de analyses en het schrijven van de manuscripten op sleeptouw nam. Zijn waardevolle opmerkingen, verbeteringen en suggesties zijn overal in dit onderzoek terug te vinden.

Met Ida Dielemans heb ik in het onderzoek lange tijd zeer nauw samengewerkt. Onze verschillen in anpak konden tot verhitte discussies leiden. Dit verhinderde echter niet dat we bleven samenwerken, veel plezier hadden, en het tot een goed einde wisten te brengen.

Een aantal mensen hebben een grote rol gespeeld in de totstandkoming van de manuscripten. Naast beide promotores was Rick Grobbee belangrijk wegens zijn kritische commentaar en heldere suggesties. Jacqueline Witteman leerde me dat een klein onderzoek groot kan worden als je het maar met geduld en zorgvuldigheid aanpakt. Ook met Michiel Bots was het prettig opgeruimd samenwerken. Met Ronald Stolk heb ik onder andere met zeer veel genoegen de publieke relaties van ERGO verzorgd.

Het proefschrift is gebaseerd op gegevens die in de eerste ronde van het ERGO onderzoek werden verzameld. ERGO zou niet bestaan hebben zonder de leiding van bij aanvang, Frank van den Ouweland, en later Bert Hofman, Rick Grobbee, Paulus de Jong en Huib Pols. Ook Michael Koenders (automatisering) en Peter Boerlage (beheer) hebben hierbij een onmisbare rol gespeeld.

Else Odding, Janny van Gastel en Ronald Stolk dank ik omdat zij de moeilijke taak op zich hebben genomen om de gang van zaken in ERGO te regelen.

Het oogheelkundig onderzoek werd voor een zeer belangrijk deel uitgevoerd door Els Baars, Diane Bakker, Ada Hooghart en Anneke Korving. Het was zwaar, maar ik kan me niet herinneren dat er een dag is geweest waarop ik niet met hen gelachen heb. Ook Roger Wolfs ben ik dankbaar voor het feit dat hij bij de staart van ERGO I een groot aantal Ommoord diensten heeft overgenomen. Lous Ruempol heeft alle ups en downs van dichtbij gedeeld. Michel Hijmering en Stijn Kramer hebben een zeer gewaardeerde bijdrage geleverd met het beoordelen van de dia's.

Maxime Look en later Douwe Algra en Hanneke den Breeijen waren altijd 
beschikbaar bij netelige BMDP problemen. Huib Burger, Paul van Daele, Cock van Duijn, Caroline Klaver, Arend Mosterd en Ronald Stolk heb ik met veel plezier van hun werk mogen houden.

Verder wil ik noemen ERGO-collega's Anske van der Bom, Monique Breteler, Jules Claus, Arno Hoes, Bèr Pleumeekers, Maarten de Rijk, Marieke Visser en Dorothee Wientjens en ERGO medewerkers Irene Bannink, Ingrid de Boer, Astrid Breinburg, Ton de Bruijn, Corinna Brussee, Lydia Buist, Wil van Deelen, Gerrit-Anne van Es, Marcel Eijgermans, Ans Frijters, Micheline de Haes, Inge Haumersen, Elly van der Heiden, Elisabeth van Herpen, Ed Hillenaar, Diane Huizer, Els Hylkema, Marianne IJsselstijn, Jeanette Kamman, Hilda Kornman, Sari Laukkanen, Hilda Mathot, Hanneke van Meurs, Eric Neeleman, Margriet van Rees, Robert Rosier, Ria Rijneveldshoek, Chris de Ruiter, Monique Slijkhuis, Dick Slof, Sonja Snijders, Toos Stehman, Wilma Verbruggen, Jeanette Vergeer, Rene Vermeeren, Lilian Verwey, Marianne Walthaus, Miranda Weggeman, en Sam Yoja.

De deelnemers van het ERGO onderzoek zijn uiteraard onmisbaar geweest. Om redenen van privacy moeten zij anoniem blijven. Als dank zijn echter de identificatienummers van alle deelnemers op de omslag vermeld.

Ik ben bijzonder ingenomen met mijn paranymfen Huib Burger en Luuk de Boer met wie ik wetenschap, vriendschap en humor deel.

Van mijn ouders heb ik geleerd om te relativeren en geduld te hebben. $\mathrm{Zij}$ hebben mij ondanks de moeilijke omstandigheden alle mogelijkheden gegeven om mijn keuzes te verwezenlijken. Van broers en zussen wil ik met name Piet bedanken omdat hij mij altijd achter de broek heeft gezeten. Mijn schoonouders hebben steeds voor een warm en stimulerend onthaal gezorgd.

Greet ken ik nu bijna 16 jaar. Het is nog nooit zo goed gegaan. 


\section{CURRICULUM VITAE}

Hans Vingerling was born on January 1st, 1961 in Gouda, the Netherlands. He passed secondary school in 1980 at the 'Christelijk Lyceum' in Gouda. From 1980 to 1981 he studied mechanical engineering at the 'Hogere Technische School' in The Hague. In 1981 he started his medical studies at the Erasmus University Medical School in Rotterdam, where he graduated in September 1988. From September 1988 until September 1989 he worked as a resident in the Department of Ophthalmology at the St Franciscus Hospital in Roosendaal (H.E. van Endt, R. Kramer, H. Wessels, ophthalmologists). From November 1989 until August 1994, he was a research fellow, at the Department of Ophthalmology, Erasmus University Rotterdam. This thesis was prepared at the Department of Ophthalmology (Head Prof. Dr. P.T.V.M. de Jong) and at the Department of Epidemiology \& Biostatistics of the Erasmus University Rotterdam (Head: Prof. Dr. A. Hofman). In August 1994, he started his specialty training in ophthalmology at the University Hospital RotterdamDijkzigt. 



$$
\text { , }
$$




\section{.}

